\title{
Contribución al Estudio de la Masticación de las Hojas de Coca
}

\author{
Por
}

NESTOR USCATEGUI MENDOZA 
La coca es buena para el hambre, para la sed, para la fatiga, para el calor, para el frío, para el dolor, para la alegría, para todo es buena. Es buena para la vida. A la coca preguntan los brujos a quién desee "catipar". Con la coca se obsequia a los cerros, las lagunas y los ríos encantados. Con la coca sanan los enfermos; con la coca viven los vivos; llevando la coca entre las manos se van los muertos. La coca es sabia y benéfica.

(Ciro Alegría. El Mundo es Ancho y Ajeno, pág. 289. Ediciones Ercilla. Santiago de Chile. 1940).

Desde las épocas más remotas, los pueblos del mundo, en sus prácticas mágicas y religiosas en busca del inexplicable mundo sobrenatural, o persiguiendo el desdoblamiento de su personalidad en el universo psíquico, o bien procurándose un estímulo fisiológico-psíquico que les permita sobreponerse al hambre, a la melancolía, a la fatiga y a los complicados problemas del sexo, en fin, deseando liberarse de la implacable realidad, han utilizado sustancias embriagantes, aletargantes y estimulantes, contenidas en su mayor parte en el reino vegetal; así, los sacerdotes egipcios acostumbraban a ingerior dosis progresivas de cicuta, para hacer más llevadero su voto de castidad; los mexicanos usaron desde remotos tiempos el peyotl en sus ceremonias mágicas o en sus ritos religiosos; los brujos del Africa negra emplearon el yohimbo y el iboga, para provocar la embriaguez preparatoria a las grandes iniciaciones fetichistas; el yagé se utiliza en Colombia y en el Amazonas para producir una embriaguez visionaria; en la India se conoce el delicioso haxis que produce ilusiones voluptuosas; el opio de la China es bien conocido por sus tremendos efectos y finalmente encontramos el té, el café y el tabaco, deliciosos estimulantes que han conquistado todo el mundo. Por qué nos ha de extrañar entonces, el que algunas tribus indígenas de América del Sur, mastiquen las hojas de la coca con el fin de aplacar el hambre, la sed y el cansancio. Naturalmente la utilización de estas hojas la hacen agregándole cal, con lo cual consiguen liberar el alcaloide contenida en ellas, que no 
es otro que la cocaína, tan útil a la medicina y farmacia moder$n_{i}$ 's, pero que es usada por miles de seres en el mundo entero, cumo droga estupefaciente, constituyendo este empleo el vicio denominado cocainomanía, que ha sido proscrito por las leyes de los países actuales y es considerado como perjuicial a la salud individual y social. Desafortunadamente en esta humanidad que marcha día a día hacia una psicosis depresiva, son inútiles las campañas para detener el avance de esta droga. El hombre moderno que lleva una existencia exuberante y veloz, no podrá liberarse ya, del vertiginoso paso que lleva el progreso humano. Esa vida tan agitada de por sí, sigue su curso inexorable y llevará a las generaciones futuras a través de todas las conquistas de la mente humana, hacia un mundo plagado de enfermedades mentales, hacia una humanidad mentalmente desequilibrada. Entonces sí que será un problema grave controlar el consumo de estupefacientes, porque el mundo los estará buscando como la única forma de escapar a la realidad y encontrar mundos ilusorios.

Pero no debe confundirse en ningún momento el empleo de la cocaína químicamente pura por los toxicómanos, con la masticación de las hojas de coca con la adición de sustancias alcalinas. Esta última forma de empleo de la coca no constituye una toxicomanía, sino un hábito. Así nos lo dice en forma muy clara el Consejo Económico y Social de la Organización de las Naciones Unidas, en el informe de la Comisión de estudio de la Coca, en la forma siguiente: "No parece en el momento actual que el mascado de las hojas de coca pueda ser mirado como una toxicomanía en el sentido médico. El comité de expertos en drogas capaces de producir manía, dio la siguiente definición en su reunión del 9 de enero de 1950. Definición de toxicomanía. Habiendo considerado la solicitación de la Comisión de Drogas Narcóticas, el comité estableció la siguiente definición de toxicomanía: "La toxicomanía es un estado de intoxicación periódica o crónica en detrimento del individuo y de la sociedad, producido por el repetido consumo de droga (natural o sintética). Sus características comprenden: 1) Un deseo o necesidad irresistible (compulsión) de continuar tomando la droga o de obtenerla por cualquier precio. 2) Una tendencia a aumentar la dosis. 3) Una subordinación psíquica, sicológica y a veces física a los efectos de la droga. Comparando con esto, las observaciones de la comisión 
demuestran que el mascado de hojas de coca no es una toxicomanía, sino un hábito (1).

Además de estas conclusiones podríamos citar las de la Comisión Peruana para el Estudio de la Coca, que son idénticas en cuanto se refiere a la naturaleza del coqueo, aunque difieran en otros puntos, de las de la Comisión de las Naciones Unidas (2).

Establecido este precedente vamos a hablar un poco de la planta, su descripción, clasificación botánica y su extensión, así como de los pueblos indígenas americanos que la usan, de las variedades de su uso y antigüedad.

La cosa es un arbusto de 1 a 2 metros de altura, con hojas de color verde claro, ovaladas, sencillas y generalmente esparcidas, de flores poco vistosas, de color blanco y fruto pequeño en drupa de color rojo. Crece en los valles cálidos de los Andes a una altu. ra que oscila entre los 1.000 y 2.000 metros, aunque hay especies que se cultivan por debajo o sobre estos límites. Pertenece al Género Erithoxylum y a la familia Erithroxyláceae. Las especies más conocidas son: Erithroxylom Coca Lam. y Erythroxy. lom Novogranatense. (Morris) Hieron. Se cultiva actualmente en el Perú, especialmente en Paucartambo, los valles de Carabaya, Huanuco y Santa Ana. En Bolivia, en las provincias de Yungas, Yurucares, Ynquisivi, Caupolicán y Lacareja. En Colombia, principalmente en los Departamentos de Magdalena, Santander del Sur, Boyacá, Cundinamarca, Huila, Cauca y Nariño. En Argentina, Chile, Brasil, India, Ceylán, Australia y Formosa. Su uso se remonta a la época precolombina y su origen se pierde en la noche del tiempo.

Histórica y arqueológicamente se ha comprobado que la masticación de la coca, fue una costumbre muy antigua en Nicaragua, Panamá, los Andes de Colombia, Ecuador, Perú y Chile. En épocas más recientes se extendió por la región amazónica y llegó hasta el Brasil. Los principales pueblos que tuvieron esta costumbre y que la conservan hoy día entre sus descendientes son: el Aymará, el Quechua y el Chibeha.

Su uso presenta algunas variantes según la época, la región o la cultura en la cual se encuentra. Según las más antiguas crónicas, en el Perú y desde tiempos de la conquista española, la coca fue utilizada mediante la adición de sustancias alcalinas que

(1) El Problema de la Coca. Perú Indígena. Vol. III. Nos. 7 y 8. Lima, 1952, p. 28.

(2) Ibid., pág. 63. 
constituyan la llamada "tocra" o "llicta", que consiste en piedra caliza o tierra, o bien de caracoles y otras conchas calcinados, a la cual se agrega en ocasiones cenizas de mazorca de maíz sin grano, o de Quinoa (Chenopodium quinoa. Willard) $u$ otras se. millas y hojas. Llevadas a la boca las hojas de coca madura previamente tostadas en recipientes de barro y masticadas suficientemente con ayuda de la saliva, hasta formar con ellas una bola, se les va añadiendo las cenizas con un palillo o una espátula de hueso y se mastican hasta obtener un sabor dulce, teniéndolas en la boca hasta la desaparición de éste, hecho lo cual se bota la mascada y se reemplaza con una nueva. Durante esta operación el "acullicador" o "chabchador" (nombre que se la da al individuo que masca la coca en el Perú y Bolivia) escupe un jugo verdoso, mezcla de saliva y zumo de la hoja, el que muy rara vez traga.

Actualmente es de empleo general en casi toda el área andina entre los grupos indígenas, con adición de cal obtenida de piedras calizas calcinadas y preparadas de modo especial o de conchas también quemadas y pulverizadas. Desde un tiempo más o menos largo ha penetrado el uso de la coca en el área amazónica. Su empleo difiere del de de los Andes. Allí las hojas de coca son tostadas y pulverizadas, para ser mezcladas luégo con cenizas de hojas de Yarumo (Cecropia), junto a las cuales se tamizan y el polvo obtenido de esta operación es guardado en un bolso hecho de fibras vegetales, la boca del cual cual se cierra con un hueso ahuecado y por medio de él se absorbe dicho polvo, que es masticado y tragado lentamente. En algunos grupos indígenas se acostumbra mezclar la coca con cazabe y cenizas de hojas, ingiriéndola también poco a poco.

Entre los Chibcha de Colombia esta operación se llama "mambear" y "mambe", es decir, la cal es llevada en calabacitos colgando del hombro o de la cintura, mientras que las hojas de coca tostadas se llevan en bolsas de lana o fibras vegetales primorosa. mente tejidas. En el Perú y Bolivia y el Norte de Argentina, el empleo de la coca recibe el nombre de "acullicar" o "Chabchar" y la substancia alcalina o las cenizas que la representan se llevan en estuches de madera o hueso y en bolsas apropiadas para tal uso; las hojas de coca también se portan en bolsas tejidas de lana.

En algunas regiones se acompaña la coca con el zumo de tabaco concentrado, como entre los indios de la Sierra Nevada de Santa Marta y entre los Huitoto del Amazonas, particularidad 
que es necesario examinar detenidamente ya que es un hecho curioso el encontrar la masticación de la coca contigua al área de uso del tabaco. Parece que en Centro América, las Antillas y Colombia el uso del tabaco es anterior al de la coca. Es lógico suponer que la primera utilización del tabaco fuera ingerirlo y que el aspirarlo como rapé o el fumarlo ya en puros o en pipas de barro u otros materiales, fueran usos posteriores. El hecho de hallar la costumbre de usar el tabaco como masticatorio con la adición de cal, entre algunas tribus de la costa del Pacifico colombiana, posteriormente a la difusión de la coca, hace suponer que fuera una influencia del uso de ésta y la adición de zumo de tabaco concentrado al masticatorio de coca, parece ser una mezcla de los dos usos en la cual prima naturalmente el de la coca por llenar más completamente la función que se perseguía. Naturalmente el empleo del tabaco como masticatorio con la adición de cal, pudo existir en forma independiente del de la coca y sin influencias del uso de ésta, ya que la masticación de hojas y la geofagia son dos costumbres muy antiguas en la humanidad; lo importante en este caso es hallar el pueblo que utilizó primero la mezcla de hojas que contenían substancias aletargantes o estimulantes y les mezcló cal, empleando este conjunto como masticatorio. Se ha dicho que esta costumbre pudo provenir de la Polinesia en donde se masticaban las hojas de un arbusto llamado. Betel con la adición de cal y otras substancias, pero esto solamente se explica para la América del Sur, por suponerse que a este continente llegaron migraciones provenientes de Polinesia. En todo caso, ya sea por paralelismo cultural o por difusión, lo evidente es que la masticación de la coca con adición de cal y de tabaco, se encontraron en América del Sur a la llegada de los españoles como nos lo dicen los cronistas de esa época y es también evidente que la masticación de la coca prevaleció en el área andina seguramente porque existía un fuerte factor cultural que condicionaba su uso; y el tabaco, difundido previamente en varias tribus colombianas, diversificó su uso y permaneció contiguo al área de existencia de la coca, pues contiguo a ésta se hallaron grupos Arawak y Karib entre quienes el tabaco existía antes de la penetración de la coca; de este modo debemos establecer que mientras la coca fue llevada por tribus Chibcha, el tabaco lo fue por tribus Arawak principalmente y posteriormente por tribus Karib.

Sobre la masticación de la coca se ha escrito abundantemente en América en estos últimos años. Se ha tratado el punto desde 
varios aspectos, pero sobre todo desde el aspecto médico y con el consiguiente perjuicio para el estudio global del problema, se le ha querido dar el carácter de una toxicomanía. Quienes han estudiado el caso desde un punto de vista imparcial y refiriéndose a casi todos los aspectos del problema es decir a los aspectos botánico, químico, agrícola, médico, cultural y social, están de acuerdo en admitir que la masticación de las hojas de coca debe considerarse como un hábito y no como una toxicomanía. Me refiero en primer lugar a la meritoria labor de la Comisión Peruana para el Estudio del Problema de la Coca.

Desde el año de 1927 se ha venido estudiando en el Perú, la fisiología del hombre del altiplano. En 1931 fue creado el Instituto de Biología Andina, del cual es director el doctor Carlos Monge. Esta institución ha trabajado tesoneramente al lado de entidades tales como el Departamento de Físiopatología de la Facultad de Ciencias Médicas del Perú, en el estudio del hombre andino y fue esta entidad la que influyó considerablemente en el ánimo del Consejo Económico y Social de las Naciones Unidas; para que se realizase un estudio sobre el terreno, a fin de determinar el efecto de la masticación de las hojas de coca sobre el organismo humano en general y algún organismo en particular. Este estudio se realizó en colaboración con la Organización Mundial de la Salud. Para tal efecto fueron nombradas dos comisiones: una, la Comisión de Encuesta de las Naciones Unidas y otra la Comisión Peruana. La primera fue presidida por el señor Howard B. Fonda, Vicepresidente de la Asociación Americana de Productores Farmacéuticos y de la cual hicieron parte, el señor Jean-Fhillipe Razet, Director de la oficina de Estupefacientes de las N. U., el Profesor Federico Verzar, doctor en medicina, Presidente de la Sociedad de Fisiología de Suiza y Director de la FAO de las N. U., el doctor Marcel Alfred Garnier-Deyeux (Venezuela), médico experto en farmacología. La Comisión Peruana fue presidida por el doctor Carlos Monge, y formada a su vez, por el doctor Fortunato Carranza, Decano de la Facultad de Farmacia; el Ingeniero Alberto León, Director de la Escuela Nacional de Agricultura; el doctor Enrique Encinas, Catedrático de Psiquiatría; el Ingeniero Juvenal Monge, Catedrático de Economía; el doctor Alberto Guzmán Barrón, Catedrático de Bioquímica; el doctor Manuel Sánchez Palacios, Catedrático de Derecho Rural, Aguas e Industria y Derecho Procesal Civil; el doctor Jorge E. Castañeda, Catedrático de Derecho Civil; el doctor 
Humberto Aste-Salazar, Profesor de Fisiopatología de la Universidad Mayor de San Marcos; el señor Carlos Avalos, Jefe del Departamento de Control de Estupefacientes del Ministerio de Salud Pública y Asistencia Social, y el señor Andrés Lindow, Administrador del Estanco de Coca.

La Comisión de las Naciones Unidas verificó su labor en el Perú y Bolivia, desde el 11 de septiembre de 1949, hasta mayo de 1950, llegando a las conclusiones y recomendaciones siguientes:

A) La Comisión reconoce la complejidad del problema de la masticación de las hojas de coca, problema que no puede considerarse como fenómeno aislado, sino como consecuencia de las condiciones económicas y sociales en que viven grandes sectores de las poblaciones del Perú y Bolivia.

B) La masticación de las hojas de coca constituye un peligro por la cocaína que contienen.

C) No considera la masticación de la hoja de coca, como una forma de toxicomanía, en el sentido médico de la palabra, sino más bien como un hábito.

D) Considera que la masticación produce efectos perjudiciales en el organismo, tales como: la inhibición de la sensación de hambre y la consiguiente desnutrición, modificaciones desfavorables en el individuo, de naturaleza intelectual y moral, restándole posibilidad de alcanzar un nivel social más alto; y, por último, disminución del rendimiento económico del trabajo, manteniendo un nivel económico de vida muy bajo.

E) Reconoce el valor nutritivo de la hoja de coca en lo que respecta a su tenor en vitaminas, pero concluye que debido a la asociación con la cocaína que contiene, en ningún caso puede considerarse la masticación de la hoja de coca como un substituto de una alimentación adecuada.

F) Considera al hombre de los Andes perfectamente aclimatado a las grandes alturas.

G) Como solución al problema, propone la Comisión: Mejorar las condiciones de vida de la población en que la masticación es un hábito generalizado, limitar la producción, reglamentar la distribación y suprimir la masticación de la hoja de coca.

H) Supresión gradual de la masticación de la hoja de coca, que teniendo en cuenta la complejidad del problema, no sea ni 
tan larga que permita la continuación perjudicial del mismo, ni tan corta que pueda lesionar los intereses económicos en juego." (3)

Este informe provocó el informe preliminar de la Comisión Peruana, presentado el 26 de noviembre de 1950. En dicho informe se hace constar que: "Los expertos nombrados por el Consejo Económico vinieron al Perú no para estudiar científicamente el problema sino para hacer labor meramente informativa".

Sobre las conclusiones y recomendaciones de la Comisión de las Naciones Unidas, me referiré únicamente a los puntos principales criticados por la Comisión Peruana, y son los siguientes: Sobre la aclimatación del hombre en los Andes, "asegura la Comisión repetidamente que el hombre de Ios Andes puede estimarse como una variedad físiológica de raza humana". Es un hombre distinto del de el nivel del mar porque sus reacciones físiológicas, sus índices bioquímicos son siempre diferentes en intensidad, en cantidad y aún en el sentido de su acción. Hay tal desconocimiento sobre estos hechos que precisamente las erróneas opiniones que los autores extranjeros, al contemplar la difícil aclimatación del europeo, emitieron sobre los pobladores de Méjico y de los altiplanos del Perú, asegurando que estas razas estaban condenadas a desaparecer, motivaron los estudios que sobre aclimatación en la altura han sido iniciados en el Perú". (5)

Resumen:

1) Dentro del común denominador de la raza andina hay en el Perú, Ecuador y Bolivia, distintas agrupaciones étnicas, en cierta medida específica, por sus expresiones antropológicas, físicas, fisiológicas y culturales.

2) El aspecto físico de estos países depende de la configuración que le prestan la cordillera y la selva; y la distribución humana aborigen, al parecer, corre parejas con esta estructura.

3) El cultivo y aprovechamiento de la coca es correlativo con la geografía física del país, y su influencia por ende distinta en sus grupos humanos.

4) Una investigación antropológica se está llevando por el el Instituto de Biología Andina con el propósito de desarrollar

(3) Perú Indígena. Op. cit., pp. 27 a 36.

(4) Ibid, p. 47.

(5) Ibid., p. 53 , 
puntos relativos a la naturaleza específica de la materia, y sus relaciones con el hábito de la masticación de la coca."

"Hay una relación directa entre la altitud y el consumo de la coca. Los pobladores altiplanos al bajar a nivel del mar dejan fácilmente el hábito. Las poblaciones propias de los valles cálidos donde se produce la coca, y las del nivel del mar no hacen uso de ella.

La conclusión es evidente: se mastica coca, sobre todo allí donde la atmósfera enrarecida de las altiplaniecies crea condiciones funcionales que la reclaman posiblemente. Sólo una investigación inteligente y sin prejuicio podría dar la respuesta definitiva." (6)

El Problema científico-Fisiología Andina.

La tesis de trabajo de los investigadores peruanos es que la variación del medio ambiente produce en los sujetos aclimatados un nuevo equilibrio fisiológico: El Hombre es un todo con su ambiente.

Si esto es así, es evidente que el medio interno del andino es distinto del medio interno del hombre al nivel del mar, y por consiguiente, no puede aplicarse al andino los datos fisiológicos y bioquímicos establecidos por la ciencia creada a nivel del mar. Es una ciencia nueva de la de la Biología de la altiud." (7)

Sobre otro de los puntos planteados por la Comisión de las Naciones Unidas, es decir, sobre aquel que sostiene que la masticación de la coca mantiene un estado constante de desnutrición y disminuye el rendimiento económico del trabajo, se pronuncia la Comisión Peruana con la enumeración de hechos que indican lo contrario. A este respecto convendría leer las observaciones del Profesor Alberto Hurtado, quien ha permanecido más de un año en el altiplano del Perú, realizando experiencias sobre este caso. (8)

Es sobre uno de estos puntos que tengo que disentir de las tesis propuestas por los investigadores peruanos. Estos dicen que "hay una relación directa entre la altitud y el consumo de la coca". No creo que exista esta relación, al menos entre los grupos indígenas colombianos, puesto que gran parte de la población indígena que vive actualmente en el área amazónica consume las hojas de coca y esta población vive en regiones cálidas. Lo que

(6) Perú Indigena. Op. cit., pp. 55-56.

(7) Ibid., p. 56.

(8) Ibid, pp, 71-74. 
yo he sostenido y a ello me referiré en este trabajo, es que esta costumbre tuvo origen en la región andina y que de aquí pasó al Amazonas, donde ha venido incorporándose a la cultura de los grupos que allí habitan. De tal modo que yo me pregunto si la afirmación de los científicos peruanos no es muy arriesgada; puesto que el consumo de la coca no sólo se realiza "allí donde la atmósfera de las altiplanicies crea condiciones funcionales que la reclaman", sino en toda la cuenca de los grandes ríos que atraviesan las regiones selváticas de Colombia. Es lógico suponer que no es el factor aclimatación el que ha impulsado a estos individuos a utilizar la coca, sino otras necesidades de diverso orden. Es decir, sin restarle mérito a la tesis de trabajo de los investigadores peruanos de que "la variación del medio ambiente produce en los individuos aclimatados un nuevo equilibrio fisiológico", debo permitirme dudar si para el logro de ese equilibrio fisiológico sea necesaria la acción de la coca, ya que otros individuos en condiciones disímiles la consumen igualmente.

También en el Perú, sostiene la tesis contraria a la del Instituto de Biología Andina, la escuela eneabezada por el prestigioso hombre de ciencia, desafortunadamente ya fallecido doctor Carlos Gutiérrez Noriega, el cual escribió en apoyo de su teoría numerosos artículos de los cuales, muy a mi pesar solamente he podido leer algunos.

De la misma escuela es el médico peruano Carlos A. Riketts quien rebate punto por punto, en uno de sus artículos las tesis del doctor Monge, aunque por otra parte desconoce el alcance del uso de la coca en nuestro país, puesto que dice: "En Colombia, son los Departamentos del Cauca y Huila con sus comarcas vevinas, las únicas fuentes de producción de la coca y son también las únicas regiones donde se coquea; en las alturas no se masca." (10) En esto acusa una deficiente información, puesto que en Calombia no solamente se coquea en los Departamentos del Cauca y Huila, sino al Norte del Departamento de Nariño, en el Departamento del Magdalena, entre las tribus indígenas de la Sierra Nevada de Santa Marta y entre gran parte de los indígenas que viven en nuestras intendencias y comisarías, como informaré de-

(9) Gutiérrez Noriega. El Hábito de la coca en Sudamérica y El hábito de la coca en el Perú. En Revista América Indígena. Vols. XII y IX, respectivamente.

(10) Ricketts. La masticación de las hojas de Coca en el Perú. América Indígena. Vol. XIV. 
talladamente a lo largo de este trabajo. Dice también que en el Ecuador ha desaparecido este uso, pero yo diría que no totalmente, puesto que hay aún tribus habitantes del Noroeste de este país donde todavía se conserva este hábito. Naturalmente son tribus muy reducidas y este uso no representa en el Ecuador sino un pequeño porcentaje. Al referirme al Ecuador debo hacer mención a los artículos de los doctores Luis A. León y Víctor Gabriel Garcés (11), en los cuales tratan de la extinción del uso de la coca en este país y las causas de ella.

En nuestro país poco se ha escrito al respecto. Desde el punto de vista botánico ha sido tratado ligeramente por César Uribe Piedrahita y Pérez Arbeláez. Desde el aspecto médico, los abanderados de la campaña de la destrucción del cocaísmo han sido los médicos Gerardo Bonilla Iragorri y Jorge Bejarano, quienes han publicado algunos artículos sobre el particular (12). Sobre el aspecto social y etnológico del problema, han escrito Juan Friede y Luis Duque Gómez, cortas notas al respecto. El objeto de este trabajo es el de contribuir a esclarecer algunos aspectos del problema y esperamos que esto se logre al menos parcialmente.

\section{BOTANICA DE LA COCA}

La coca pertenece al Género Erythroxylum y a la Familia Ery. throylaceae. Las plantas de esta Familia son leñosas, con hojas simples, generalmente esparcidas, estípulas y flores actinomorfas, por lo común inconspicuas. Cáliz y corola pontámeros; los pétalos con apéndices ligulares en la cara interna. Androceo de 10 estambres soldados en la base. Fenómenos de heterostilia muy frecuentes. Ovario de 3 a 4 compartimientos, de los cuales sólo uno continúa su desarrollo ulterior. Compartimiento fácil con 1 o 2 rudimentos seminales colgantes, de rape ventral. Micrófilo exterior y superior. Fruto en drupa (1).

Sus especies más conocidas y que contienen el alcaloide cocaína en mayor o menor proporción, son: Erythroxylum coca. Lam, cuya distribución es la siguiente: Perú, Bolivia, Brasil y Colombia.

(11) y (12) Véase bibliografia.

(1) Wettstein. Tratado de Botánica Sistemática, p. 765. 
Erythroxylum novogranatense. (Morris) Hieronymus, cuya distribución es: Indias Occidentales, Trinidad, Brasil, Perú, Guinea, Guayana Británica, Venezuela y Colombia.

En Colombia se han encontrado las siguientes especies: Ery. throxylum hondense. H.B.K. Distribuída así: Magdalena, Cundinamarca, Atlántico y Antioquia.

Erythroxylum popayanense. Triana y Planch. Distribuída así: Colombia (2).

Parece que la especie originario de la planta era silvestre en los valles cálidos de Colombia y el Perú, pero las especies cultivadas son las más conocidas. La coca primitivamente no existía sino en los valles cálidos con alturas de no más de 2.000 metros y no menos de 1.000. Posteriormente fue domesticada posiblemente en el Perú y surgieron especies más fácilmente adaptables a las diversas alturas. En mi concepto la especie más antigua debe ser el Erythroylum coca, pues no se encuentra ésta ni por encima ni por debajo de los límites dados, y más recientes deben ser el E. Novogranatense, cuyas plantas se encuentran a alturas mayores y el hondense y popayanense que se hallan a alturas menores.

En resumen, de las especies conocidas actualmente, parece ser $1 \mathrm{E}$. Coca, la más antigua y su sitio de domesticación fue probablemente el Perú. No obstante el auge que tuvo su cultivo en este país, podemos pensar que esta planta fuera originaria de otro sitio, posiblemente Colombia, donde crecía silvestre en las hondonadas cálidas de los Andes y de donde fue llevada al Perú en épocas muy remotas y domesticada allí, presentando su cultivo un incremento tan extraordinario, que fue objeto de intercambio comercial con otros pueblos, difundiéndose así su uso de modo sorprendente.

(2) The Genus Erytroylum in Colombia. By Walter A. Gentner. Consultado en la monografía original, por cortesía del Instituto de Ciencias Naturales de Bogotá. En este trabajo, el Género Erytroylum tiene 24 especies, cuya composición química no se ha estudiado en su gran mayoría, por lo tanto se ignora si existe o no cocaína en ellas. Por otra parte, el material del Herbario Nacional de Colombia, no se ha estudiado aún, en lo referente al men. cionado género y se va a estudiar, para agregar los datos al trabajo de Gentner, que será publicado próximamente. 


\section{LINGUISTICA DE LA COCA}

Hemos tratado de desentrañar el origen de la coca y de su uso por medio de la lengua usada para denominarla en diversas regiones de Centro América, Colombia, Venezuela y Perú. Desafortunadamente no todos los autores dicen cuál es el nombre empleado por los indígenas para designar la planta y se limitan únicamente a mencionar el hecho de que es utilizada, pero sin constatar si se conoce con el nombre clásico de coca o tiene otra deno. minación.

Entre las lenguas del antiguo Perú, el nombre más primitivo que se conoce es el Aymará "kkoka" (1), adaptado luego por los Kestchua a su lengua con la variante cuca o coca. Naturalmente dada la antiguedad de la lengua Aymará es lógico pensar que esta planta era conocida por éstos desde tiempos muy anteriores a la Conquista, aunque no podemos dar una fecha cierta para ello.

Los cronistas de Conquista nos dicen que la coca fue llamada "hayo" o "hayu", entre los indígenas de Venezuela, el Norte de Colombia y entre el pueblo chibcha de Boyacá y Cundinamarca (Departamentos de la actual Colombia), desde los primeros tiempos de la llegada de los conquistadores (2). Actualmente se le conoce con este nombre entre las tribus Chibcha de la Sierra Nevada de Santa Marta. El origen de esta palabra es muy incierto, pues aunque se encuentra entre algunas palabras dejadas por los cronistas, de la lengua Tairona, no corresponde a ésta, ni tampoco a la Chibcha (3) y suponemos que se trata de un término de origen centroamericano, pero hasta el momento ignoramos su verdadero origen. Lo único evidente es que los Chibchas de la Sierra Nevada la tomaron de los Taironas y que se encuentra exclusivamente en grupos Chibcha; por ejemplo, entre los Tunebo al Este de Boyacá, se la conoce con el nombre de "hayo" y además con el de "asa" (4). Por el contrario entre los indígenas de Nicaragua se la denominó "yaat", en la época de la Conquista (5), mientras que êntre las tribus del grupo linguístico Kokonu-

(1) Sebeok. Materials fron Aymara Dictionary. En Journal de la Societé des Americanites. N. S. T. XL. 1951, p. 118.

(2) y (3) Véase Cap. V de este escrito.

(4) Rivet. La Langue Tunebo. En Journal de la Societé des Americanistes. T. XVI. 1924. p. 64.

(5) Lothrop. Pottery of Costa Rica and Nicaragua, p. 35. 
ko, en el Departamento del Cauca (Colombia) se la nombra "naase" (6) y entre los Paeces de Tierradentro, se llama "esh" (7), aunque actualmente es más usado el nombre ketschua.

Después de una rápida búsqueda entre las lenguas indígenas de las comisarías e intendencias de Colombia, hemos encontrado los siguientes nombres: En gran parte del Amazonas, se le da el nombre de "hibie", entre los Huitoto según Koch-Grumberg (8) y según autores más modernos la plabra es "jibbiae" (9). Según estos últimos, entre los indios Miraña (Tribus en la boca del río Cahuinarí, afluente en la margen derecha del bajo Caquetá) se le llama "jipi" y en cambio entre los Rosiggaro (Indios que residieron en la sabana del río Cahuinarí, actualmente extinguidos o diseminados por otras partes) se la llama "jibie", y en lengua Okaina, que pertenece según Castellví (10) a la Macrofamilia lingüística Witoto, el nombre usado es "jibbi", de lo cual deducimos que fueron probablemente los Huitoto los difusores de este uso en el Amazonas, ya que su extensión en esta región es tan grande y se encuentra la misma denominación con ligeras diferencias en varias lenguas de la misma, muchas de las cuales pertenecen a la familia lingüística Witoto.

Entre los Tukano del Vaupés se le denomina "pato" (11) y se dice que en el Caquetá se conoce como "hayuelo" y "spadic", y en el Amazonas como "ipadú", aunque no se nos dice a qué tribus indígenas pertenecen estos nombres (12).

Como vemos, son muy diferentes las denominaciones dadas a la coca por los indígenas de América. Entre ellas es necesario eliminar las de las tribus indígenas de las comisarías e intendencias de Colombia, las empleadas en el Departamento del Cauca y la usada en tiempos de la Conquista en Nicaragua, por ser nombres regionales que no alcanzan mayor extensión. Después de es.

(6) Rivet. Le grupe Kokonuko. En Journal de la Societé des Americanistes. N. S. T. XXXIII, p. 41.

(7) Información del Etnólogo Segundo Bernal Villa.

(8) Koch. Grumberg. Les Indiens Ouitotos. En Journal de la Societé des Americanistes. T. III. Paris, 1906, p. 169.

(9) Cartagena (Alberto de) Mis. Cap. Palabras indigenas relacionadas con "Los Apuntes sobre el baile" en algunas tribus de la región SurOriental de Colombia. En Revista Amazonia Colombiana Americanista. T. V. Nos. 17-19. Sibundoy. 1953, pp. 26, 29, 31 y 33.

(10) Castellví. La Macrofamilia linguística Witoto. En Amazonia Colombiana Americanista. T. V. Nos. 17-19. Sibundoy. 1953, p. 16.

(11) Información del Etnólogo Marcos Fülop.

(12) Pérez Arbeláez. Plantas Medicinales de Colombia, p. 165. 
ta eliminación no nos quedan sino dos palabras de donde podríamos deducir el origen de la planta y son: el nombre "hayo" usado por los grupos Chibcha y el de "kkoka" del Aymará. Evidentemente sería muy aventurado imaginar teorías sobre el origen de la palabra "hayo" y no podemos asegurarle una antigüedad mayor al tiempo de la Conquista. Por lo tanto, debemos suponer que ya que la lengua Aymará, se le atribuye una antigüedad de varios siglos antes de la Conquista y que en ella se encuntra la palabra "kkoka", es muy lógico pensar que el conocimiento de es. ta planta sea muy antiguo en las regiones habitadas por los representantes de esta cultura, aunque no podemos dar una fecha exacta para confirmar este hecho.

\section{MITOS Y LEYENDAS SOBRE EL ORIGEN DE LA COCA}

Los Mitos y Leyendas que se conservan sobre la coca, no nos permiten asegurar cuál fue realmente el país de origen de esta planta. Solamente podemos remontar sus orígenes al Perú preincaico. El hecho de atribuír a Manco Capac, personaje semilegendario, la revelación de la planta, nos revela que ésta era conocida desde tiempos muy anteriores a la conquista y seguramente por pueblos de lengua y cultura Aymará, como nos lo prueba la existencia de la palabra "kkoka", que pasó luégo al keetschua.

Las leyendas sobre el origen del Imperio Inca nos llevan a la región del lago de Titicaca, desde donde se dice que partió Manco Capac a fundar este Imperio. Hasta el momento lo único que podemos aceptar como histórico, es que la cultura incaica fue precedida de otra cultura bastante avanzada, que tuvo su centro en Tiahuanaco y se difundió por medio de tribus colla (Aymará), dando origen al Imperio Inca. En todo caso la existencia del uso de la coca en tiempos preincaicos es evidente por el hallazgo en tumbas muy antiguas, de bolsas para la coca, de atados de hojas y de diversos objetos destinados a este uso; y el hecho de encontrar la palabra coca en la lengua Aymará, indica un co. nocimiento muy antigua de esta planta.

Una antigua leyenda peruana cuenta que una hermosa cortesana perseguida por sus pecados, fue muerta violentamente, encontrándose en su vientre en forma milagrosa, una planta con virtudes misteriosas y carácter mágico, a quien los antiguos perua- 
nos atribuían toda suerte de poderes (1); esta pIanta fue la coca. Naturalmente esto indica el acentuado concepto de divinidad que le daba el pueblo peruano, agricultor por excelencia, a todos los productos del suelo, de los cuales derivaba alguna utilidad, A este respecto nos dice Frazer: "Los peruanos creían que todas las plantas útiles estaban animadas por un ser divino que ocasionaba su crecimiento. Según cual fuera la planta, esos seres divinos eran llamados: madre del maíz (mama zara), madre de la patata (mama axo), madre de la quinua (mama quinoa), madre de la eoca (mama coca). Las figuras de estas madres divinas se hacían respectivamente de panojas de maíz y hojas de quinoa o de la coca, que se vestían con ropas de mujer y se adoraban después" (2).

Evidentemente el carácter sagrado de la coca predominó en el Perú en tal forma que en un principio solamente fue usada por los sacerdotes y el Inca, pero posteriormente pasó al pueblo, no perdiendo su condición de divinidad y así fue usada en todas las ceremonias con las cuales se quería honrar a los dioses.

En general, vemos que la coca tiene en el Perú un pasado legendario que se remonta a varios siglos antes de la conquista española y aunque no podemos asegurar que este país fue su cuna, al menos podemos decir que el uso de esta planta tiene tal antigüedad que debemos manifestar que es el sitio de origen de esta costumbre.

Entre las tribus indígenas colombianas, los mitos y leyendas sobre el origen de la coca, no son muy numerosos y poco nos dicen sobre el verdadero origen de esta planta. Me refiero a unos pocos mitos y leyendas obtenidos en algunas tribus indígenas de la actualidad y en regiones muy disímiles. La mayor parte fue obtenida entre el grupo Kogi de la Sierra Nevada de Santa Marta, por investigadores del Instituto Etnológico, hoy Instituto Colombiano de Antropología, en distintas épocas.

En primer lugar encontramos la leyenda obtenida por el Etnólogo Milciades Chaves entre los Kogi y que nos habla del origen de la cosa entre este grupo: " $L a$ coca. En un principio no había haiu (coca); los indios tenian mucha hambre; entonces Sintana pidió haiu a la Magri. Alli donde vivía la Magri estaba una mujercita pequeña a quien Sintana trajo y la convirtió en mata de

(1) Pardal. Medicina Aborigen Americana, pág. 286.

(2) Frazer. La Rama Dorada, ed. 1951, pág. 454. 
haiu. Nuaniskague, hijo de Sintana, la sembró en un tronco; cuando la planta creció cogieron la semilla y la trajeron a Taminaka en Palomino; allí, en un plan muy bonito, se sembró la coca.

La Magri fue la primera que comió poporo; entonces ella tenía su casa ceremonial (Kansa-María); un día Sintana fue a cocinar por mandato de la Magri pero no quedó bueno; la comida estaba fea; entonces Sintana fue a coger coca y luégo vino a cocinar, pero también poco quedó bueno. La Magri fue a coger coca y luégo cocinó y todo quedó muy bueno. Ella antes de que cogiera coca tenía bigote, pero vio que no le quedaba bien y se lo quitó.

Entonces Sintana ordenó a los hombres que no cogieran coca porque la mata se seca, sino que deben hacerlo únicamente las mujeres y también dijo que las mujeres no coman coca porque les duele el estómago, tendrán diarreas y dolores de muela. Asímismo dijo que el hombre no comería coca antes de su bautizo, pues, el Mama debe bautizar y entregar la coca, el calabazo, el palito para llevar el mambe a la boca y el chipichipi (conchas para la cal). También debe aconsejarlo para que coma coca cuando se encuentre reunido en la Casa Ceremonial para que oiga los consejos y converse con sus compañeros" (3).

Esta leyenda no nos dice mucho sobre el verdadero origen de la coca, pero sí nos muestra cómo la necesidad alimenticia llevó al pueblo Kogi al uso de la coca y que la división del trabajo por sexos tiene un origen mítico-religioso, así como las restricciones que existen para su uso.

Nuevamente aparece el origen de la coca entre los Kogi, en dos mitos obtenidos por el Etnólogo Gerardo Reichel-Dolmatoff. El personaje central de estos mitos es Sintana, pero a su alrededor aparecen otros que se transforman en animales y actúan como tales o como hombres según las necesidades que se presenten. El primero de los mitos dice lo siguiente: "Sinatana vivía en el cielo. Su hija era Bunkueiji: el venado. Cuando estaba en la casa ella era mujer, pero cuando salía afuera, ella se volvió venado. Un día Bunkueiji dijo a Sintana: "Padre, tú no tienes coca". Sintana dijo: "No tengo". Entonces dijo Bunkueiji: "Te voy a buscar coca". Entonces ella dijo a su hermano Hirvuixa:

(3) Chaves Mitología Kágaba. Boletîn de Arqueología. Vol. II. Nos. 5-6, 1947, pág. 492. 
"Vete tú a la playa a buscar conchas para quemar y yo voy a la tierra a buscar coca para nuestro padre". Hirvuixa bajó del cielo y se fue a la playa y Bunkueiji se volvió murciélago y también bajó a la tierra. Llegó a Noaneiji. Allí vivía Máma Ili y tenía mucha coca sembrada. Bunkueiji se volvió venado y puso sus cachos entre las hojas verdes de las matas. Entonces las hojas se quemaron y cayeron al suelo. Llevó nueve mochilas llenas a Sintana. Entonces Ili vio que toda su coca se había quemado y dijo: "Seguro aquí cohabita una mujer con un hombre. Por eso mi coca se quema". Tomó una tinaja grande y la enterró y se escondió en ella para ver quién dañaba su coca. Entonces vio Ili cómo vino un venado. Puso sus cachos entre las hojas y éstas se secaron. Ili lo cogió de un pie y dijo: “¿Por qué me robas mi coca?”. Vino mucha gente y todos dijeron: "Tienes que pagar multa por robar coca". Bunkueiji dijo: "Mi padre va a pagar multa"." "No, tú tienes que pagar", dijeron todos. Entonces Ili cohabitó con Bungueiji y se casó con ella.

Cuando Bunkueiji aún no era mujer, ella era un venado y quemaba la coca con sus cachos. Pero ahora ya quedó mujer y ya no la puede quemar. Por eso los hombres no deben coger las hojas verdes sino las mujeres. Pero los hombres deben quemar las hojas y no las mujeres" (4). Aquí en este mito vemos una relación directa de la coca con los problemas del sexo. Primero en la observación que hace Ili: "Seguro aquí cohabita una mujer con un hombre. Por eso mi coca se quema". Esto quiere significar probablemente que el hecho de tostar las hojas al fuego, indica un acto sexual, por lo cual no deben quemar coca sino únicamente los hombres, porque de hacerlo las mujeres significaría una provocación a cohabitar. EI hecho de casar a Ili con Bunkueiji a modo de pago, significa que debe pagar con su cuerpo por haber quemado la coca. En resumen, el mito parece una explicación Kogi del acto sexual simbolizado en la coca.

El siguiente mito, obtenido también por el Etnólogo Reichel, nos habla lo mismo que el anterior de personajes que se transforman en animales y nos deja entrever algo sobre el origen de la coca. Este mito dice lo siguiente: "Antes no había coca. Los antiguos usaron otra hierba que ya no hay y que se llama guanguala.

Un hombre y una mujer tenían una hija. Ella tenía el cabello

(4) Reichel-Dolmatoff. Los Kogi. T. II, págs. 56 y 57. 
largo hasta la cintura, y cuando lo sacudía cayeron hojas de coca sobre el suelo. Así el padre de la muchacha tenía coca. Entonces había un Máma que se llamaba Teyuna (Tairona). El pensaba siempre: Cómo hago para conseguir coca? Entonces Teyuna se volvió pájaro-hembra e hizo su nido en la orilla del río. La muchacha iba cada día a bañarse y allí vio al pájaro blanco y lindo. El pájaro era mansito y la muchacho lo cogió cada vez cuando fue al río a bañarse y le hizo cariños. En su casa la muchacha contó lo del pájaro y dijo que le quería mucho, pero su padre dijo: Este pájaro es malo. No lo toques. Pero la muchacha se fue al río. Acarició al pájaro y lo besó y le quería tánto que le dio de beber saliva de su boca. Entonces un día el pájaro dijo: Me quieres mucho? Sí, dijo la muchacha. Te quiero mucho. Entonces dijo el pájaro: Tira de la cuerdita que tengo en la mitad de la cabeza. La muchacha buscó en su cabeza y encontró la cuerdita. Tiró de ella. Entonces se partió el pelo de la cabeza y cayó hacia atrás, y Teyuna salió y abrazó a la muchacha. Después Teyuna se fue y la dejó sola en la orilla del río. En su casa Teyuna se sacudió el cabello y dos semillas de coca cayeron al suelo. Teyuna las sembró. Pronto crecieron y así Teyuna tuvo coca. El la dio a otros" (5).

Lo más importante de este mito es la referencia que hace del uso de una planta distinta de la coca que probablemente debe ser la coca silvestre y la aparición de un sacerdote con nombre que significa Tairona, indicando que el sacerdocio y la institución de la coca, llegaron a los Kogi por medio de los Tairona, cosa bastante probable, como lo asegura la arqueología de la región.

Los mitos siguientes fueron obtenidos entre tribus Huitoto del nas-Tribu "ainene" de dialecto Menéka, familia lingüística Witoto). y dice lo siguiente: (fragmento) "Después Huma salió de un hueco de debajo de la tierra (que todavía existe en la trocha que va a Igaparaná a la casa del indio Atama) de donde salieron también las tribus ainene, muruy, andoke, bora, akaima, nomuya, etc., que habían de poblar esta región. Después salió un hom. bre llamado Búineyma, con "candela"; pusieron a calentar agua, donde se bañaron toda la gente de todas las tribus y los repartió por todas partes, dándose semilla de toda planta, especialmente de coca, tabaco, palos de yuca, piña" (6).

(5) Reichel Dolmatoff, op. cit., págs. 55 y 56.

(6) Javier de Barcelona. Huma. El Tesmóforo Hitoto. En revista Amazozonia. Tom. II. $N^{0} 4$, pág. 42. 
El segundo mito recibe el nombre de "El Primer Sabio, su hija y el árbol más grande del mundo". Y dice lo siguiente: "Había una mujer llamada Jiteruiquesa (Xiteruiquesa) que quiere decir hija del primer sabio; y el primer sabio se llamó Jiteruime y dicen todos que fue el primero que existió en este mundo y que les enseñó todo lo que saben. Dicha mujer era sumamente buena y no le gustaba juntarse con los hombres, pero dio a luz un hijo llamado Menerama (sabio) dentro de una vasija y lo tapó con otra. La india fue a avisar a su padre del alumbramiento, quien al destapar la vasija, encontró en vez de un niño una pequeña planta. La trasplantó y fue creciendo hasta llegar a ser el árbol más grande del mundo. Una vez desarrollado, fue produciendo todas las frutas y frutos de la tierra, como yuca, plátano, caña, coca, etc." (7).

Como podemos ver, estos mitos poco o nada nos dicen sobre e] origen real de la coca y únicamente dejan en nuestra mente ese concepto primitivo, que le da a los productos del suelo un origen legendario o mítico, muy poco relacionado con la realidad. Mucho más cerca de la realidad se encuentran las leyendas peruanas, que nos remontan hasta la época de la cultura Aymará, muchos siglos antes de la conquista. La lingüística y la arqueología confirman esta hipótesis, que nos vemos inclinados a aceptar, por ser la más verosímil y tener el mayor número de pruebas.

\section{ORIGEN DE LA COCA Y DIFUSION DE SU USO EN COLOMBIA}

Hemos visto por medio de la Botánica y la Lingüística, que los más antiguos caminos que conducen al país de origen de la coca, nos llevan hacia el Perú. Del mismo modo, los mitos que se conservan sobre el origen de la planta nos conducen también, al antiguo país de los Aymará y Ketschua.

Naturalmente desde el punto de vista estrictamente científico, no podemos admitir que la coca tuvo realmente su origen en los valles cálidos del Perú; pero si no podemos admitirlo como verdad científica con pruebas irrefutables, debemos reconocer que en realidad todos los caminos conducen hacia el mismo sitio y si en conciencia nos es imposible admitir como país originario

(7) Jacinto Ma. De Quito. Dos mitos de Ia Tribu Jidua. En Revista Amazonia. Tom. II. No 4 , pág. 48. 
de esta planta al antiguo Perú, al menos podemos decir que fue ta fue domesticada y cultivada a diferentes altitudes, que su cultivo tuvo un desarrollo sorprendente, tegiéndose alrededor de ella una serie de mitos y leyendas y dándole un nombre sencillo, compendio de todo el reino natural en medio del cual se yergue como una diosa verde y misteriosa, a quien rinde culto todo un pueblo, que se sirve de su savia vigorizante para alejar el hambre, la sed y la fatiga, sobreviviendo gracias a ella, por varios siglos a la lucha por obtener el diario sustento. Fue también este pueblo quien llevó la magia verde de la hoja, hacia tierras lejanas, donde con otros nombres se difundió por la cordillera de los Andes, junto a una cultura milenaria, religiosa y mítica, que condicionó su uso y permitió su supervivencia a lo largo del tiempo.

Fue grande mi sorpresa al notar cómo, a medida que penetraba en el laberinto bibliográfico de mi documentación sobre la coca, encontraba que, tanto botánicos, médicos e historiadores, como etnólogos, todos se referían al Perú como supuesto país originario de la planta. Fueron vanos mis esfuerzos, para desvirtuar estas afirmaciones, ya que todas las informaciones recogidas lo confirmaban. Entre los muchos que afirman esto se encuentra el historiador Mortimer (1), quien da como país originario del cocaísmo al Perú, de donde después de la conquista incaica, se extendió posiblemente a los pueblos vecinos. También el etnólogo José Pérez de Barradas dice lo siguiente: "Conviene hacer resaltar dos puntos, la relación estrecha de la coca con la religión y que su patria originaria fueron los valles calientes del Perú" (2). Por su parte el médico Gutiérrez Noriega, escribe así: "Las investigaciones históricas y arqueológicas, demuestran que el hábito de la coca, existía en el Perú, desde la época preincáica en la costa y en la sierra". (3). Esta afirmación marca evidentemente la gran antigüedad de la coca en el Perú y realmente la arqueología ha encontrado abundantes pruebas del uso de la coca en esta época. En las tumbas pertenecientes a culturas anteriores a la Inca, se han hallado atados de hojas de coca, bolsitas tejidas

(1) W. Codden Mortimer. Perú History of Coca. The Divine Plants of Incas.

(2) Pérez de Barradas. Antigüedad del uso de la coca en Colombia. En Revista de la Academia Colombiana de Ciencias Exactas, Físicas y Naturales. Vol. III. No 11. Bogotá, 1940.

(3) Gutiẻrrez Noriega. El hábito de la coca en el Perú. En América Indígena. Vol. IX. No ${ }^{o}$ 2. México, D.F., 1949, p. 144. 
que contienen hojas, calabazos con cal, cenizas y espátulas, tanto en la costa como en la sierra. Además, los cronistas nos hablan claramente del uso de la coca en el Perú desde tiempos muy antiguos.

Naturalmente no faltan quienes, en una forma muy original y tremendamente anticientífica, quieran negar estas afirmaciones, basándose únicamente en la especulación. Así encontramos al médico Jorge Bejarano, quien escribe a este particular lo siguiente: "Hay hechos (cuáles?) que hacen presumir que la coca fue conocida antes de los Incas por los Arhuacos, cuya patria se cree estaba en la región Noroeste de la América del Sur, tal vez en la Guayana y quizá en la actual Colombia" (4). En primer lugar no se nos dice cuáles son estos hechos, y segundo por un gran desconocimiento de las fuentes etnohistóricas y etnológicas se refiere el autor a los Arhuacos (nombre genérico mal aplicado desde tiempos de Conquista a las tribus que habitaban las estribaciones de Ia Sierra Nevada de Santa Marta), confundiendo este nombre con el de Arwak, que es la denominación de una familia lingüística de América. A continuación presenta una serie de hipótesis sin mayor fundamento científico, que sería inoficioso comentar, a pesar de que cita en apoyo de ellas algunos etnólogos nacionales y extranjeros, pero interpretando sus conceptos a su acomodo. En general vemos que el médico Bejarano no aclara suficientemente estos puntos y seguramente no se informó muy bien al respecto.

$\mathrm{Al}$ abordar el problema de la coca y su origen, he tratado desde todo punto de vista de apartarme de la especulación, y por esa causa he buscado pruebas históricas, arqueológicas y etnográficas que le den a este trabajo el verdadero carácter de búsqueda científica de la verdad y si en algunas ocasiones a falta de esas pruebas tengo que acudir al recurso de la hipótesis, esas suposiciones quedan en tal condición y nunca han tratado de pasar el terreno de la duda, dejando al tiempo el esclarecimiento de ellas.

Es muy probable que la costumbre de masticar hojas que contienen principios enervantes y estupefacientes no sea eminentemente americana. El hecho de encontrarse dicha costumbre desde tiempos muy remotos entre los indígenas de la Polinesia, quienes

(4) Bejarano. Nuevos conceptos sobre el cocaísmo en Colombia. En América Indigena. Vol. XIII. $N^{\circ}$ 1. México, D.F., 1953, p. 18. 
se dedican a masticar las hojas de una planta llamada betel (Piper Betle L.) mezclándola con substancias alcalinas, denota cierta relación con la costumbre de masticar las hojas de coca de ciertos grupos indígenas americanos. Esto fue observado por numerosos cronistas y viajeros, entre ellos don Antonio de Ulloa, Boycastle y el Padre Valera. En realidad es notable la similitud de su uso con el de la coca, y aunque si bien es cierto que el betel es una especie botánica completamente distinta de la coca, ya que se trata de un arbusto trepador de la familia de las Piperáceas, no deja por ello de notarse una gran analogía en la forma de usarlo. En efecto, las hojas frescas de este arbusto, que tienen un sabor algo picante y amargo, se recolectan apenas empiezan a amarillear y se usan como masticatorio mezcladas con nuez de areca y cal viva, más o menos como se hace con la coca. Además, el uso del betel es muy antiguo, encontrándose difundido desde tiempos remotos, desde las Molucas hasta las riberas del río Amarillo y desde las del Ganges hasta las orillas del mar Negro. Los Malayo-polinesios son muy aficionados a emplearlo, encontrándosele en la mayoría de las islas del Pacífico. Es considerado objeto de lujo y muy necesario; se acostumbra ofrecerlo a los huéspedes en señal de hospitalidad, y en ocasiones se ofrece como regalo en bolsitas de seda y cofrecitos ricamente adornados.

Su preparación es objeto de esmerado cuidado, las tres subs. tancias que entran en ella son: la hoja del betel, la nuez de areca y la cal obtenida por calcinación de moluscos. En ocasiones se hace entrar en la mezcla tierra del Japón, gamber, hojas de tabaco, polvo de China, cardamomo, alcanfor, madera de áloe, almizcle y ámbar gris. Los rajás de la India, varían la fórmula agregándole substancias aromatizantes. Este uso tiene infinidad de variantes según los pueblos.

El sabor del betel es muy complejo, participando del acre y del amargo, sus efectos son los de astringente y excitante de la secreción salivar, además produce fenómenos de estimulación que se traducen por un gran aumento del apetito y gran actividad digestiva, así como una ligera excitación cerebral. El abuso del betel produce una embriaguez análoga a la del opio o el haschich, pero menos pronunciada. Se le atribuyen propiedades inmunizantes, pero lo cierto es que a la luz de los modernos conocimientos no produce efectos capaces de inmunizar contra las enferme- 
dades tropicales. En general, vemos que en algunos aspectos recuerda los efectos de la coca, si bien sus propiedades no son aletargantes como en aquella, pero en todo caso sí estimula la actividad cerebral, coincidiendo con la coca en este aspecto.

En fin, el hecho de hallar esta costumbre establecida desde remotos tiempos entre los pueblos que habitan el archipiélago de la Polinesia, hace suponer que fueran estos quienes llevaran la costumbre de masticar hojas a la América del Sur, si bien esta teoría descansa en bases muy débiles. En todo caso, el Profesor Rivet, al hacer el paralelo de los elementos polinésicos, con los americanos, anota "la mezcla de cal a ciertas substancias como masticatorios" (5) y más adelante habla de una posible migración polinésica hacia América cuando dice que "hay otras islas más remotas, que únicamente pueden ser islas polinesias, de donde venían en las épocas precolombinas, en grandes piraguas, unos extranjeros para traficar con los indios de las costas del Perú", y en forma clara dice: "Qué de sorprendente habría en que los polinesios, que fueron los más prodigiosos navegantes del mundo, hubieran alcanzado en sus viajes la costa americana?" (6) Dejemos planteado este interrogante y pasemos a considerar la antigüedad de la costumbre de masticar las hojas de coca en América.

Son numerosos los cronistas y viajeros que nos han dejado relatos sobre el uso de la coca en el Perú. Pedro Cieza de León, el célebre cronista de la conquista y uno de los más dignos de crédito, quien viajó por esas tierras desde 1547, escribe a este respecto: "En el Perú en todo él se usó de esta coca en la boca, y desde la mañana hasta que van a dormir la traen sin echar de ella. Preguntando a algunos indios por qué causa traen siempre ocupada la boca con aquesta hierba (la cual no comen ni hacen más que traerla entre los dientes) dicen que sienten poca la hambre y que se hallan en gran vigor y fuerza" (7). Y el Padre Joseph de Acosta, nos habla en forma muy clara de la coca cuando dice: "Es, pues, la coca tan preciada, una hoja verde, pequeña, que nace en unos arbolillos de obra de un estado de alto; críanse en tierras calidísimas y muy húmedas; da este árbol cada cuatro meses esta hoja, que se llama allá tres mitas. Quiere mucho cui-

(5) Rivet. Orígenes del Hombre Americano, pág. 140.

(6) Ibid., pág. 185.

(7) Cieza de León. La Crónica del Perú. $3^{a}$ Edic. 1941, pág. 283. 


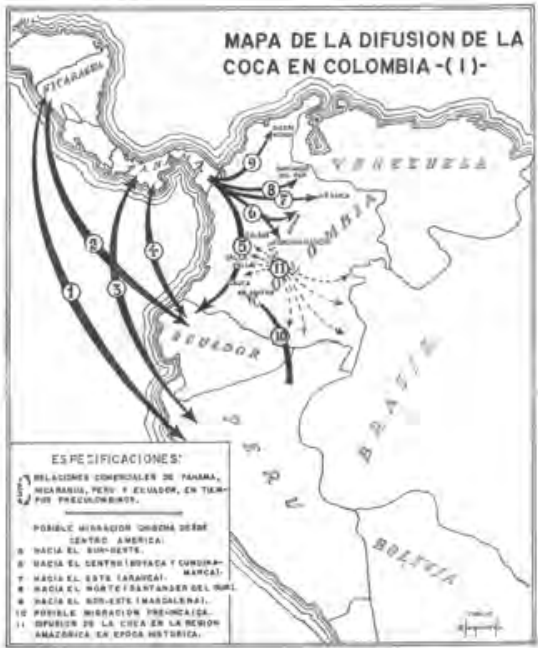


dado en cultivarse, porque es muy delicada, y mucho más en conservarse después de cogida. Métenla con mucho orden en unos cestos largos y angostos y cargan los carneros de la tierra que van con esta mercadería a manadas con dos o tres mil cestos. El ordinario es, traerse de los Andes, de valles de calor insufrible, donde los más del año llueve; y no cuesta poco trabajo a los infelices indios, ni aún pocas vidas su beneficio, por ir de la sierra y temples fríos a cultivarla y beneficiarla y traerla" (8)

El célebre viajero y naturalista don Antonio de Ulloa nos dice en sus escritos sobre el Perú: "La coca es planta muy común en los territorios altos de aquella parte; el modo de usarla es con la tierra llamada tocra o llipta, que es una pasta que componen a manera de bollos de chocolate aunque algo mayores y del mismo color; estos son preparados con las cenizas de la mazorca del maíz sin granos y la de algunas otras plantas silvestres abundantes de sales, lo cual amasan juntos, y queda duro cuando está seco. Los coqueros que son por lo regular indios, muestran graciosamente estos ingredientes en proporcionada cantidad a los que se la compran, que sin ellos le falta la mejor sazón a la hierba. Es muy grande el aprecio que los indios hacen de ella y no trabajarían a gusto si les faltase; antes de dar principio se sientan a prepararla, lo cual se llama acullicar, y poniéndose en la boca una porción de tocra, la van humedeciendo y reduciendo a una pelota; cuando la tienen bien amasada la sacan y ponen en la bolsa o saquillo en donde guardan la coca y tomando otra porción hacen con ella lo que con la primera; esto lo repiten hasta tener cinco o seis bolas; que son las que consumen en dos o tres horas de trabajo. Luego que se les acaba, vuelven a acullicar para seguir adelante con la obra; cada bola la mantienen en la boca todo el tiempo que sienten el gusto áspero y fuerte de la hoja; cuando le falta la arrojan y toman otra. Usan de unas bolsas hechas del pellejo de algún animal pequeño como el zorrillo, $\mathbf{u}$ otro equivalente, y en este traen la coca y la tocra pendiente de la cintura, al modo como en Europa los que usan el tabaco traen el polvo en caxas, y el humo el bolsas proporcionadas para ello (9).

También el Inca Garcilaso, dedica buena parte de sus obras a contar de la coca y así comienza: "No será razón dexar en olvido la yerba que los indios llaman cuca y los españoles coca,

(8) Acosta. Historia Natural y Moral de las Indias. Edic. 1894, T. I, p. 330.

(9) Ulloa. Noticias Americanas, págs. 468 y 470. 
que ha sido y es una de las principales riquezas del Perú para los que la han manejado en tratos y contratos; antes será justo que se baga mención de ella largamente, según lo mucho que los indios la estiman, por las muchas y grandes virtudes que de. lla conocían antes y muchas más que después los españoles han esperimentado en cosas medicinales" (10).

En el Perú son numerosos los cronistas que hablan de esta ta planta, pero las primeras noticias que llegaron de ella a Euro. pa se remontan al año de 1499 , probablemente porque la con. quista del Perú no tuvo lugar sino unos años después. El religioso Tomás Ortiz quien acompañó a Pedro Alonso Núñez y a Cristóbal Guerra, a la costa norte de Sur América, consignó el uso de la coca llamada por los naturales hayo, quienes la mascaban adicionándole substancias alcalinas (11). Con la misma denominación, pero más tarde (en 1514), Fray Bartolomé de las Casas habla del uso de la planta, entre los naturales del Norte de Sur América, en la forma siguiente: "Desde que llegan los muchachos a diez o doce años, traen todo el día si no es cuando beben y comen, en la boca dos bocados del tamaño de una nuez de las hojas de un arbol llamado hayo, como de arrayán, uno en el uno, y otro en el otro carrillo, las cuales cierto, son las hojas que en el Perú llaman coca, que en tanto precio es notorio las estiman. Estas hojas les fortifican los dientes y muelas de tal manera que nunca se les pudren ni sienten dolor en ellas, pero páranles la dentadura como una azabaja negra" (12).

Sobre quién dio primero la noticia en Europa diserepan los autores. Así don Gonzalo Menéndez Pidal escribe: "Monardes, que es el primero en dar noticias en Europa del empleo que los indios hacían de la coca mascada con cenizas, dice "toman al. mejas o conchas de ostra y quémanlas y muélenlas después de quemadas; quedan como cal y muy molida y toman unas hojas de coca y máscanlas, como las van mascando, van mezclando con ellas de aquel polvo hecho de las conchas, de modo que hacen dello una como una pasta, llevando menos del polvo que de la yerba; y de esta masa hacen unas pelotillas redondas y pónenlas a secar, cuando quieren usar de ellas toman una pelotilla en la boca y chúpanla pasando de una parte a otra, procurando conser-

(10) Inca Garcilaso. Comentarios reales de los Incas.

(11) Pardal., op. cit., pág. 287.

(12) De las Casas. Historia de las Indias. Cap. CCXLIV. 
varla todo lo más que pueden." (N. Monardes: De las cosas que traen a nuestras Indias, pág. 114). "Más adelante cita nuevamente a Monardes quien escribe: "Es cosa general el uso della entre los indios para muchas cosas; para cuando caminan por necesidad y para su contento cuando están en su casa" (13).

En todo caso, sea cualquiera que fuese el sitio de América, desde el cual se llevaron a Europa las primeras noticias sobre la coca, ellas fueron llevadas en la época histórica americana, es decir pasados varios siglos después de la difusión de la planta en América. Lo cierto es que sólo fue a mediados del siglo XVI, cuando los efectos producidos por la masticación de las hojas de coca fueron descritos por Benzoni y solamente en el siglo pasado, el principio activo de las hojas, es decir, la cocaína, fue obtenido por Nieman, según unos, y por Gaedeke según otros, y sorprendentemente a finales del mismo siglo Anreb descubrió la acción anestésica local de la cocaína; su introducción en la terapéutica moderna data sólo de 1894, por lo tanto es justo hacer mención de un descubrimiento debido a los indígenas de América del Sur, que después de varios siglos fue utilizado en Europa.

Hecho este breve paréntesis, continuaremos con la investigación del camino que siguió la coca en América. Hemos visto cómo una serie de pruebas nos llevan a asegurar que la costumbre de masticar las hojas de la coca tuvo origen en el Perú preincaico. Ahora bien, el hecho de hallarse la planta y su uso en la América Central y en el Norte del continente Sur Americano, hace surgir en nuestra mente una serie de interrogantes. Vamos a tratar de explicar el por qué de hallazgo de la coca y la costumbre de su uso en dichos sitios.

Es una evidencia históricamente comprobada que las culturas peruanas preincaicas, alcanzaron en su extensión el territo. rio ecuatoriano, sin hacer mención del Imperio Inca, que conquistó una gran parte del territorio de esa nación. Es así mismo evidente la existencia del cocaísmo en épocas preincaicas en el Ecuador. Luis A. León escribe a este respecto: "La arqueología médica y las obras de los cronistas nos dan a conocer que en épocas precolombianas el uso de la coca estuvo extendido en casi todo el país; nuestras colecciones arquelógicas son muy ricas en piezas de cerámica antropomorfa, que representan a los coqueros llevando uno o dos bolos de coca en la boca, que se manifies-

(13) Menéndez Pidal. Imagen del Mundo hacia 1570, pág. 38. 
tan exteriormente por la presencia de eminencias globulosas en uno o en ambos carrilos. En lo que toca a la arqueología del litoral ecuatoriano es también abundante en esta clase de piezas; las obras del doctor Marshal Sabille (Marhal H. Sabille, Archaelogical resedrches on the coast of Esmeraldas. Berhankunden 16 International en Amerikanisten. 1908. p.p. 331 y s. s. Contribution to South American etnology. The antiquities of Manaví. New York. 1910. T. II, pp. 183-253) contienen interesantes ilustraciones de ejemplares de cerámica procedentes de las provincias de Esmeraldas y Manaví". A continuación nos dice el doctor León que a conseguido piezas arqueológicas con representaciones de individuos usando la coca durante sus visitas a la Tola, La Tolita y otros sitios de la región de Esmeraldas. Ilustra su artícu. lo con fotografías de ceramios representando individuos en actitud de hacer uso de la coca, tomadas de la obra de Enrique Festa, Carlos E. Grijalva y Jacinto Jijón y Caamaño, encontradas en regiones de la costa y correspondientes a culturas preincaicas. Más adelante dice: "La provincia de Esmeraldas donde se ha encontrado otra de las piezas, no alcanzó a caer en poder de los Incas. Su arqueología acusa influencia de Tiahuanco". Es entonces evidente que las eulturas preincaicas del Perú se extendieron hasta el Ecuador.

Establecido el uso de la coca en el Ecuador precolombino vamos a ver cómo fue posible que esta costumbre alcanzara a Centro América en épocas anteriores a la Conquista.

El hallazgo de numerosos elementos Peruanos y Ecuatorianos tanto de orfebrería como de cerámica, en Centro América, como de elementos centroamericanos en el Perú y Ecuador, nos da base para pensar en un intercambio comercial entre estos países. Veamos lo que dice Krickeberg: "Aún existían relaciones comerciales directas entre Panamá y el Ecuador, pues ya en el año de 1513, Balboa supo por conducto de los caeiques de los Cueva de la existencia de grandes balsas de vela y del uso que hacían de las llamas. Este tráfico se efectuaba hasta en los tiempos actuales por vía marítima y sin tocar a Colombia, porque los manglares infestados de fiebres perniciosas de la costa Noroccidental de este país impedía el tráfico por tierra. Por la misma vía debe haberse llevado a cabo el frecuente intercambio cultural entre el Norte de Centro América y el Perú" (14). Esta comunicación por

(I4) Krickeberg. Etnología de América. Pág. 347. 
mas se explica por el hallazgo de elementos exóticos en una y otra parte, que en otra forma no pudieron haber llegado. Entre esos elementos llevados a Centro América se fue la planta de coca y con ella la costumbre de su masticación. Sobre la existencia de su uso en América Central nos hablan numerosos cronistas y algunos autores modernos. Veamos que nos dice el arqueólogo Lothrop, quien en sus investigaciones por esta región tuvo portunidad de encontrar pruebas de la existencia de esta costumbre: "Ferdinand Columbus refiere que los nativos de la costa Norte de Veraguas, especialmente en la tierra del cacique Urina, estaban acostumbrados a usar una clase de polvo y que este arriunaba (o al menos decoloraba) sus dientes. Es posible que se refiera al uso del tabaco mastido con cal. Oviedo (T. III. Lib. XXIX, cap. XXVIII, pág. 137) definitivamente asegura que la hierba llamada "Yaat" en Nicaragua es la misma que la llamada coca en Perú". Más adelante aclara este punto diciendo: "La masticación de la coca llamada "yaat" por los Nicarao (grupo Pipil que se había establecido en Nicaragua, un siglo antes de su descubrimiento por Gil González Dávila, y que los españoles llamaron, según su jefe, Nicarao) y la cal, una costumbre localizada en la región andina; sin embargo, esta práctica parece haber sido común en Nicaragua. (Oviedo, Lib. VI, cap. XX. Los nativos encontraban alivio a su fatiga con esta droga, "por consiguiente fue familiar a las tribus de Centro América" (15).

Establecida esta prueba vamos a relacionar la cerámica centroamericana con la Ecuatoriana y citaremos nuevamente el Profesor Lothrop, quien escribe a este respecto: "Nuestra (figura 195, a), muestra una cabeza de figura humana de Coclé (Panamá) con una protuberancia en la mejilla, un rasgo muy frecuente en las figuras provenientes del Ecuador". Y a continuación: "La (figura 195, a), es una cabeza de hueso que representa a un hombre con una protuberancia en la mejilla; este ejemplar es de importancia porque representa un paralelo a las figuras de las tierras donde se mastica la coca, tales como el Ecuador (Fig. 195, b). Ya hemos citado (Fig. 17) la evidencia de que la coca fue conocida por los habitantes del Istmo y el descubrimiento de este hueso no solamente nos confirman la presencia de la coca, sino que sugiere que ella vino por comercio del Ecuador" (16). Con

(15) Lothrop. Pottery of Costa Rica y Nicaragua. Vol. I, pp. 17 y 35.

(16) Lothrop. An Archaeological Study of Central Panamá, pág. 199. 
esto tenemos fundamentada la hipótesis de la existencia de la costumbre de masticar coca, en Centro América, llegada allí por intercambio comercial con el Ecuador.

Fundamentada esta hipótesis, podemos continuar el camino que siguió la coca en su difusión a través del territorio colombiano. Evidentemente fueron los pueblos Chibcha, quienes llevaron esta costumbre hacia Colombia; por el Norte hasta la costa Atlán. tica, por el Centro hacia Boyacá y Cundinamarca y por el Oeste y el Sur represaron con ella hacia el Ecuador.

Vamos a ocuparnos en primer lugar de la emigración Chibcha hacia el centro de Colombia, que es bien conocida y tiene sus núcleos principales en Cundinamarca y Boyacá (Departamentos de la actual Colombia). Este núcleo es el que ha sido llamado con más razón Chibcha, ya que representan una unidad cultural y llegaron a establecerse en estos sitios más o menos unos dos o tres siglos antes de la conquista española. Sobre la antiguedad del estrato cultural Chibcha, los más recientes estudios se refieren a la altiplanicie de Bogotá y en general al Departamento de Cundina. marca. Se trata del trabajo realizado por los arqueólogos Emil W. Haury y Julio César Cubillos en el anguo "habitat" Chibcha de Cundinamarca. Respecto a la antiguedad de la capa cultural Chibcha dicen lo siguiente: "Las excavaciones que se han realizado en los sitios Chibchas y el examen de materiales de museo, no nos han revelado, nada que pronostique que esta cultura tenga una larga historia. Nuestros esfuerzos orientados hacia pro. fundas excavaciones debajo de los abrigos naturales favorables de Facatativá, no produjeron absolutamente nada. La inspección de numerosos perfiles erosionados, donde la cultura estuvo presente, nunca mostró más que delgados estratos y sin ningúna real antiguedad. Hasta cuando los testimonios no prueben lo contrario la conclusión al tiempo de la conquista es innegable. Trescientos años de historia de pre-conquista, parece un cálculo aceptable" (17).

Dada una posible fecha para la antiguedad de esta cultura, nos falta por averiguar la existencia del cultivo y el uso de las hojas de la coca, entre el pueblo Chibcha de estos lugares. Sobre este aspecto encontramos datos bastante fidedignos en los cronistas, que se refieren a la historia del Descubrimiento y Conquista

(17) Haury. y Cubillos. Investigaciones Arqueológicas en la Sabana de Bogotá, Boletín No 22. De la Universidad de Arizona. 1933 pp. 14-15. 
del Nuevo Reyno de Granada. Así escribe el Obispo Fernández de Piedrahita, al referirse al uso que de la coca hacían los sacerdotes Chibcha: "Hablaban pocas palabras y dormían menos, porque lo más de la noche lo gastaban en mascar hayo, que es la hierba que en el Perú llaman coca y son ciertas hojas como las de zumaque, de la misma suerte las labranzas en que las crían y cuando está la cosecha en sazón (que se reconoce por la sazón de la frutilla de sus árboles), van cortándolas con la uña del dedo pulgar, de una en una, a raíz del palillo en que nacen, y teniéndolas en mantas que previenen para ese efecto; después las ponen en una vasija de barro sobre el fuego, y tostadas las guardan, o para el comercio en que fundan su mayor riqueza, o para el gasto de casa y familia. El palillo es de muy suave olor y la hoja no es de mal gusto antes de ponerla al fuego, pero después es amargo y entorpece la lengua. $\mathrm{El}$ jugo del hayo es de tanto vigor y sustento para los indios, que con él no sienten sed ni hambre, antes los alienta para el trabajo, que viene a ser el tiempo que más lo usan, y así mismo debe ser muy provechoso para conservar la dentadura, por lo que se experimenta aun en los indios más ancianos. De antes usaban mascar esta yerba simple, pero ya la mezclan con cal de caracoles, que han introducido algunos españoles y llaman poporo, que es otro género de masa que ambrolla los sentidos. Las partes más fértiles de esta hoja son en la provincia de Sutagaos y en Soatá de la provincia de Duitama, y es de tánta estima que con ella sahumaban los Jeques a sus ídolos" (18). Queda establecido qué hacían de ella los sacerdotes, pero respecto a la afirmación de que antes usaban la hoja simple y que luégo le agregaron cal, es posible que sea imaginación del autor, puesto que noticias mucho más más antiguas nos dicen que la usaban con cal en la mayor parte del Nuevo Reino y la adición de sustancias alcalinas fue invención indígena y no española como lo dice el cronista. También hablan de la coca y su empleo de los sacerdotes Chibcha, los cronistas Pedro Simón (19) y Juan de Castellanos (20) en sus escritos sobre el Nuevo Reino de Granada.

Es bien notable la relación de la coca con la religión y las

(18) Fernández de Piedrahita. Historia general de las conquistas del Nuevo Reynno de Granada. Págs, 14 y 15.

(19) Simón. Noticias historiales de las conquistas de tierra firme en las Indias Occidentales. Pág. 291.

(20) De Castellanos. Historia del Nuevo Reino de Granada, págs 45-46. 
costumbres sacerdotales. Pedro Simón, nos habla de los ritos seguidos para la consagración de los Jeques o sacerdotes y de las ceremonias religiosas por medio de las cuales se comunicaban con la divinidad, de las que hace parte principal la coca. Todas estas manifestaciones alrededor de la hoja de esta planta, muestran una gran analogía con el uso que se le daba entre las castas sacerdotales del antiguo Perú, pero mientras para éstos representaba un importante renglón económico, entre el pueblo Chibcha, tenía que cumplir más que todo con una función ritual como lo veremos en forma muy clara en los grupos chibcha de la Sierra Nevada de Santa Marta, quienes por haber alcanzado un gran desarrollo en sus instituciones religiosas, éstas rigen toda su cultura. Entre ellos la coca desempeña un papel sublimador por medio del cual satisfacen sus necesidades alimenticias y sexuales, mejor dicho han racionalizado el uso de la coca en tal forma que ésta desempeña en su cultura función principal, librándolos de tensiones psicológicas que se vuelcan en ella a través de la religión. Más adelante veremos por qué está tan arraigado su consumo en las culturas indígenas actuales, especialmente en la cultura andina de los Chibcha. Adelantando algunos conceptos diremos que su uso obedeció en principio a condiciones sociales y económicas pero más tarde fue incorporado a sus instituciones y formó parte de la tradición cultural de estas tribus.

Continuando el camino de los grupos Chibcha hacia el Sur y siguiendo la Cordillera Central, encontramos a los Paéces en la región de Tierradentro principalmente, pero extendidos por los Departamentos de Huila, Tolima y Cauca. Estas tribus viven en esta región desde un poco antes de la conquista y aunque en esa época ocupaban un "habitat" mayor, aún conservan parte de sus tierras. Sobre la emigración de estos indios nos dice José Pérez de Barradas lo siguiente: "El último movimiento de los pueblos Chibcha sería, según nuestra teoría el de los Paéces, tal vez empujados por la invasión caribe oriental" (21). En realidad parece que este pueblo se estableció en esos sitios en épocas más recientes y tuvo que sostener numerosas guerras con sus vecinos los Pijao y se aliaron con ellos para hacer frente al conquistador español, replegándose por último hacia la región de Tierraden-

(21) Pérez de Barradas. Arqueología y Antropología Precolombinas de Tierradentro, pág. 49. 
tro que les ofrecía un abrigo natural en el cual pudieran vivir con cierta seguridad. Sobre este grupo nos hablan varios de los cronistas e historiadores de tiempos de la conquista, entre estos Lucas Fernández de Piedrahita, el cual habla ampliamente de las guerras que sostuvieron los españoles contra estos indios en todo un capítulo de su obra, que encabeza así: "Los Yalcones y Paeces toman armas y matan a los capitanes Añasco y Osorio y después a Juan de Ampudia" (22). Y Cieza de León, quien viajó por esas tierras, manifiesta lo siguiente: "Y a la parte oriental está la muy porfiada provincia de los Páez, que tánto daño en los españoles han hecho, la cual tendrá seis o siete mil indios de guerra. Son valientes, de grandes fuerzas, diestros en el pelear, de buenos cuerpos y muy limpios" (23). Estos indios antes belicosos viven hoy en completa paz, dedicados a la agricultura y también usan la coca desde tiempos de la conquista como lo dice el cronista anterior (24) y es probable que la usaran anteriormente a la conquista pues su uso se encontraba bastante extendido en tiempos de ésta.

Vamos a hacer un paréntesis para tratar aquí de la cultura de San Agustín (población colombiana al Sur del Departamento del Huila) llamada así por algunos investigadores y por otros cultura Megalítica del Alto Magdalena, este último término mejor usado, ya que la población de San Agustín fue fundada entre los años de 1608 y 1612 y la supuesta cultura hallada cerca de ella, parece remontarse a tiempos muy anteriores.

La Cultura Megalítica del Alto Magdalena es aún una incógnita en el estudio de las culturas precolombinas, a pesar de que ha sido estudiada por numerosos investigadores, pero quizá no muy minuciosamente, ya que hay muchos sitios sin excavar y aún no se han encontrado sitios de habitación, ni siquiera basureros que indiquen la permanencia en ese sitio de pueblos más o menos numerosos, como hace presumir la estatuaria en piedra tan abundante en la región.

Si bien es cierto que los indígenas de esta región tienen el hábito de la coca y también algunos mestizos, esto no se explica sino por la vecindad de grupos Paéces y otros indios que viven en las cercanías.

(22) Fernández de Piedrahita. Op. Cit. Cap. II.

(23) Cieza de León. Op. Cit. Cap. XIII.

(24) Ibid., pág. 281. 
Sobre el consumo actual de coca en la región de San Agustín he podido informarme en mi reciente viaje a esa región y debo decir que en el momento presente es muy escaso, pues fuera de algunas familias indígenas que viven en los alrededores y de mestizos cuyo número no alcanza a treinta individuos, la cifra no alcanza a un centenar. Sobre estos mambeadores mestizos ha interrogado al médico de la región, quien recuerda haber examinado cerca de veinte, con edades que fluctúan entre los 40 y los 60 años, encontrando que su estado físico es bueno en relación con el resto de la población agustianana y que solamente el hijo de uno de ellos, niño de 12 años de edad, padecía de alucinaciones que naturalmente no se pueden atribuír totalmente al consumo de la coca.

La coca se consume, pues, muy poco en la región de San Agustín, principalmente por la dificultad de obtenerla, pues solamente se consigue de contrabando que proviene en su mayor parte de Almaguer. En los alrededores de la población se observan con mucha dificultad unos dos o tres pequeños cocales, que sus dueños conservan para servirse de la hoja con fines medicinales.

Sobre la ascendencia de la población india y mestiza de San Agustín, nos habla Pérez de Barradas diciendo: "Empezaré por advertir que la población india pura o mestiza de San Agustín desciende de otro grupo Chibcha del mismo dialecto Chibchaaruak, es decir, del Andakí" (25). Naturalmente este autor mal informado, pretende que toda la población india y aún la mestiza de San Agustín, desciende del grupo Andakí. Informaciones más recientes nos permiten afirmar, que aceptar tal descendencia es un error fundamental, de acuerdo con lo sostenido por el Historiador Juan Friede, en su creciente obra "Los Andakí", en la cual afirma lo siguiente: "Pero queda demostrado que en el siglo XV los indios oriundos del Alto Magdalena no hablaban una sola lengua, y menos el idioma andakí de la selva". Y más adelante corrobora esta afirmación diciendo: "Que el nombre 'Andakíes' no es la denominación primitiva de las tribus que habitaban el Alto Magdalena, sino de las que desde la selva adyacente atacaban a aquella región durante los siglos XVII y XVIII". Y que "el idioma llamado 'andakí' es de procedencia netamente selvática" (26). Finalmente el autor nos habla sobre la clasifi-

(25) Pérez de Barradas. Op. Cit., 1940, pág. 323.

(26) Friede. Los Andakí. Pág. 78. 
cación de esta lengua en la forma siguiente: "al principio del siglo XVII se hablaban en el Alto Magdalena cuatro idiomas originarios de la región los cuales no pertenecían a la lengua selvática andakí. Por consiguiente, el origen chibcha del idioma andakí que supone Rivet no prueba que los idiomas hablados en el Alto Magdalena en el tiempo de la Colonia tuvieran el mismo origen" (27). Queda pues claramente demostrado que no fueron los Andakí, los primitivos habitantes de la región de San Agustín y que mal se puede hablar de una descendencia Andakí, cuan. do en el Alto Magdalena hubo un verdadero mosaico lingüístico, como lo comprueba la existencia de varias lenguas pertenecientes a grupos diferentes. Esto queda comprobado con la siguiente afirmación de Friede: 'La aplicación del nombre 'Andakíes' tanto a los indios selváticos como a los originarios del Alto Magdalena es, pues, errónea, y por sí sola no implica ningún parentesco étnico" (28). Esta diferencia lingüística, marca probablemente una diferencia étnica, de tal modo que no podemos hablar de un substratum étnico andakí para los pobladores de San Agustín, porque al parecer su población fue formada por varios grupos en el transcurso del tiempo y en segundo lugar porque está demostrado que los andakí no hicieron parte de ellos.

Por otra parte, si se quiere hablar de la antigüedad de la coca en la región de San Agustín, no nos podemos apoyar en el conocimiento de los pueblos que habitaban esta región un poco antes de la Conquista. A este respecto nos dice Friede: "Sin embargo, faltan datos recogidos en los tiempos de la propia Conquista, que confirmen el uso de la coca entre los indios del Alto Magdalena. Hasta ahora no se ha encontrado coca en las sepulturas indígenas, y los descendientes Andakí de la selva que viven actualmente en el Pueblo Viejo, la antigua "Ceja de los Andakíes", no la usan en su ración diaria, a pesar de vivir en la vecindad de indios venidos del Departamento del Cauca, que la mastican en grandes cantidades" (29). Y aunque el mismo autor nos habla de la existencia de cocales en el siglo XVII en el valle de Timaná, manifiesta que: "Parece que las plantaciones a que aluden los documentos datan de tiempos posteriores, cuando la conquista y la colonización trajeron consigo una apreciable inmigración de otros indios, especialmente del Perú y Ecuador que

(27) Fride. Op. cit., pág. 79.

(28) Ibid., pág. 26.

(29) Ibid. 110. 
acostumbraban a masticar la coca, o cuando esta planta llegó a constituír un codiciado artículo de comercio en el Sur, comercio que en realidad se efectuaba por vía de Timaná" (30).

Donde reside el mayor interés al estudiar esta presunta cultura, es en el hallazgo de numerosas estatuas que representan abultamientos en las mejillas y que se consideran como representaciones del acto de masticar la coca. El Profesor Preuss, quien las estudió, presenta algunas pruebas en las cuales se apoya para esta suposición (31).

Pérez de Barradas por su parte se basa en ciertas palabras de Preuss, para sostener la misma hipótesis (32). Respecto a estas apreciaciones me permito hacer algunas observaciones. La primera, se refiere a la cabeza en relieve del sitio denominado $\mathrm{La}$ Estrella, descrita por Preuss y que figura en una de las obras de Pérez de Barradas (33). Dice este autor que considera la descripción de Preuss como correcta, por lo cual se limita a figurarla, pero en otra de sus obras la presenta como la representación del acto de masticar la coca (34), representación que no le atribuye Preuss en la descripción de la misma, pues éste dice únicamente, que "los pómulos de la cara se asemejan mucho a los de otras estatuas" (35), afirmación que indica solamente un detalle en la cara de las estatuas y que se refiere únicamente a los pómulos y no a los carrillos, como se puede ver claramente en la lámina que de la mencionada figura, aparece en la obra de Pérez de Barradas. Más adelante este mismo autor, dice que, "de la gran cara triangular del montículo N.W. de la meseta B. Preuss sólo menciona en su descripción las mejillas salientes (pómulos), pero que en realidad debajo de los ojos y entre éstos y la boca, hay unos abultamientos redondeados de idéntico aspecto a los de otras estatuas" (36). Si con esto quiere dar a entender que esta cara representa la masticación de la coca, me parece infundada esta suposición, puesto que, como bien dice Preuss": "Llaman la atención en esta cabeza las mejillas salientes, que al mis-

(30) Fride. Op. cit., p. 110.

(31) Preuss. Arte Monumental Prehistórico. Traducción del alemán por Walde-Waldegg y Uribe Piedrahita. Bogotá, 1931.

(32) Pérez de Barradas. Op. cit., 1940 b, pág. 324.

(33) Arqueología Agustiniana. Bogotá, 1943, pág. 36, lám. 28.

(34) Op. cit., 1940 c, p. 324.

(35) Preuss. Op. cit., 1931 b, p. 38.

(36) Pérez de Barradas. Op. cit., 1940 d, p. 324. 
mo tiempo representan un contorno de los ojos" (37), y no he podido ver otros abultamientos que aquellos que describe Preuss y que corresponden a los pómulos de la figura, por lo tanto no se puede tomar esta estatua como la representación del acto de mambear. Para una mejor explicación a los lectores, puede observarse la fotografía que acompaña este trabajo a fin de aclarar este equívoco. Los bultamientos en los pómulos son idénticos a los de la estatua de la Estrella mencionada anteriormente.

Respecto a las cariátides del templo del montículo N.W. de la meseta A. Preuss dice que "a ambos lados de los labios se observa una protuberancia muy pequeña con la cual tal vez quiso el autor representar que la figura tenía en la boca algo con que estaba masticando (38). Aunque hoy día se encuentran algo borrosas estas protuberancias, algo de ellas se alcanza a observar en la fotografía del molde que de una de ellas tomó el investigador y que ilustra su trabajo.

Acerca de la cariátide del templo superior del montículo N.W. de la Mesita B, dice Preuss que "en las mejillas presenta - y no presentan como dice Pérez de Barradas (39) - dos protuberancias que parecen dos bolas de coca" (40). Aún en este caso que me parece el más claro de los ejemplos, como lo comprueban las fotografías que ilustran este trabajo, no se atreve el autor a confirmar como cierto el hecho.

Refiriéndome nuevamente a Preuss, dice éste que "la figura de varón con las partes pudendas representadas y una cara encima, se ven unas bolsas salientes en las mejillas que sin duda representan bocados de coca" (41). Afirmación bastante enfática y cuya prueba no aparece en la mencionada estatua.

Finalmente se refiere Preuss a dos estatuas, una procedente de la Mesita C, hoy en el Parque de la Independencia de Bogotá y otra de procedencia incierta, colocada hoy en la plaza de San Agustín. Ambas llevan en las manos una especie de bolsa y que este autor considera calabazas que probablemente contienen cal o tabaco con los cuales mezclaban la coca, y dice además que esto le hace pensar que las figuras son masculinas (42). Por su

(37) Preuss. Op. cit., 1931 c, p. 63.

(38) Ibid, p. 54, plancha 24 .

(39) Pérez de Barradas. Op. cit., 1940 e, p. 324.

(40) Prouss. Op cit., 1931, e, p. 68.

(41) Ibid, p. 83, plancha 49.

(42) Ibid, págs. 77 y 78 , planchas 43 y 44 . 
parte, Pérez de Barradas dice que estas estatuas "llevan bolsas en la mano (no calabazas como sostiene Preuss)" (43) y que lo contenido en ellas "cabe suponer el que fuese coca". Estas estatuas y la hallada por Monseñor Lunardi, descrita y figurada en su obra (44), de la cual dice que "con las manos sobre el pecho aprieta una pequeña bolsa tal vez un calabacito" y comenta a continuación la suposición anterior de Preuss, anotando varios ejemplos para confirmarlo y diciendo finalmente que "el calabacito existe además en varias de otras estatuas". Sobre esta discrepancia de opiniones no hay aún una prueba sólida que confirme la verdad, pero si se supone como dice Pérez de Barradas que estas estatuas pudieran representar una deidad a la cual estuviera consagrado el uso de la coca (45), tenemos que suponer entonces que son bolsas y no calabazas, pues aunque la calabaza sirve para llevar la cal, no se explica porqué se representa ésta y no la coca. El caso es que sea una u otra la suposición, todas conducen a presumir que sea un objeto que se relaciona con la masticación de la coca.

Por último encontramos en una de las obras de Pérez de Ba. rradas la referencia a una estatua de varón con una maza en la mano y con abultamientos circulares en la cara, que dice el mismo utor no fue conocida por Preuss. Sobre ésta (46), podemos decir que de ningún modo se puede considerar como representa. ción del acto de masticar la coca, pues los abultamientos a que hace mención el autor no se encuentran en los carillos sino en los pómulos.

En cambio ni Preuss, ni Lunardi, ni Pérez de Barradas, nada nos dicen a este respecto sobre algunas de estas estatuas que a mi modo de ver parecen representar la masticación de la coca, y son: una estatua de figura femenina con delantal y un mono a Ia espalda (47); la estatua inédita del alto de Lavapatas (48) y otra igualmente inédita de los Naranjos (49). Estas estatuas tienen abultada la boca y la última de ellas presenta abultamien. tos en los carrillos. Por otra parte la primera de ellas es consi-

(43) Pérez de Barradas. Op. cit., 1940 f, p. 324.

(44) Lunardi. La vida en las tumbas, 1935, p. 77.

(45) Pérez de Barradas. Op. cit., 1940 g, p. 324.

(46) Pérez de Barradas. Op. cit., 1943 b, p. 120, planchas 183-184.

(47) Pérez de Barradas. Op. cit., 1943 c, lámina 64.

(48) Ibid, lámina 161.

(49) Ibid, lámina 170. 
derada como femenina por Pérez de Barradas basándose en que tiene un delantal. Si se ha querido representar este sexo es probable que la masticación de la coca fuera también un hábito femenino desde esa época y no únicamente masculino como lo da a entender Preuss en su descripción de las estatuas con supuestas bolsas o calabazas.

De todo lo anterior podemos deducir que, si del examen de estas estatuas se ha concluído que parecen representar ciertas analogías con la escultura en piedra de algunas culturas preincaicas, principalmente de Chavín o Tiahuanaco, naturalmente el hallazgo en el sitio de San Agustín de estatuas que representan individuos en actitud de masticar la coca, nos indica una influencia de culturas preincaicas y consecuentemente, dada la supuesta antigüedad de esta cultura, estas influencias serían anteriores a la migración del pueblo chibcha; por consiguiente si el conocimiento de la costumbre de masticar la coca llegó a estas regiones, se debe probablemente a influencias peruanas, lo cual es muy posible dada la gran antigüedad de este uso en el Perú, pero esto queda todavía en el terreno de la duda. Mientras no se determinen bien la antigüedad y paternidad de esta cultura, todas las teorías que se nos ocurran deben quedar en calidad de hipótesis.

Hecha esta aclaración sobre la Cultura Megalítica del Alto Magdalena, continuaremos con el estudio de los grupos Chibcha entre los cuales se encuentra el uso de la coca, desde tiempos de la conquista y anteriormente.

Si miramos desde la región de Tierradentro habitada por los Paéces, hacia el Occidente, encontramos en el mismo Departamento del Cauca un grupo perteneciente al mismo tronco lingüístico, incluyéndose su lengua dentro del grupo Kokonuko. Estos indigenas son los Guambianos quienes habitan actualmente el Municipio de Silvia (Cauca) y aunque hoy se encuentran pacíficamente dedicados a la agricultura y el comercio, vivieron en otra época en guerras continuas con el español y sus vecinos, procurando conservar su independencia. Tienen mucha similitud cultural con los Paéces y hablan una lengua afín a la de éstos. Para los datos sobre su cultura hemos tomado como referencia a Gregorio Hernández de Alba (50) y en cuanto a la lingüística de este grupo

(50) Hernández de Alba. The Highland Tribes of Southern Colombia. En Handbook of South American Indians. Vol. II, 1946, pp. 914-960. 
podemos citar a Paul Rivet (51) quien nos da informaciones muy valiosas sobre esta lengua. De acuerdo con ellos los Guambianos usaban la coca mezclada con cal y este empleo se remonta a los tiempos de conquista y aunque en la actualidad este uso va desapareciendo gracias a un proceso de aculturación, aún conservan una palabra especial en su lengua para designarlo. Es muy posible que la extensión de esta costumbre haya abarcado la mayor parte de los grupos o tribus que pertenecen al grupo lingüístico Kokonuko ya que algunos indígenas de estas tribus conservan aún el uso de la coca.

Siguiendo el curso hacia el Sur de los grupos Chibcha, encontramos en los Departamentos del Cauca y Nariño, tres grupos que formaban para la época de la Conquista una cultura homogénea y son los Coaiquer, los Quillacinga y los Popayanenses. Estos grupos usaban en la época de conquista la coca con cal, como nos lo dice Hernández de Alba: "Las hojas de coca fueron mascadas con polvo de cal, llamado "mambe"; que disminuye el hambre y produce una sensación de vigor y fuerza" (52). Esta costumbre está desapareciendo en los actuales tiempos y sólo la conservan algunos grupos. A este respecto veamos lo que nos dice Sergio Elías Ortiz al hablar de algunas tribus del Departamento de Nariño, haciendo mención de los Coaiquer: "El habitual uso de la coca está desapareciendo entre los actuales Coaiquer, pero según las antiguas tradiciones de este pueblo en otro tiempo mascaba las hojas de coca como una especie de rito nacional" (53). En esta forma hemos visto cómo la coca se propagó desde Centro América por medio de grupos Chibcha a través de los Andes hasta el Sur del país.

Volviendo de nuevo hacia el camino de los grupos Chibcha esta vez hacia el Este, encontramos en esa dirección y en el De. partamento de Boyacá, en parte del Casanare y Arauca, un grupo que ha sido clasificado dentro de la familia lingüística Chibcha, como nos lo dicen Paul Rivet y Victor Oppenheim en la nota siguiente: "Merced a los trabajos del Padre Rocheraux, una de las lenguas mejor conocida de Colombia es la lengua Tunebo. Su parentesco también ha sido determinado y se trata de un dialecto

(51) Rivet. Op cit., 1941 a, pp, 1-61.

(52) Hernández de Alba. Op. cit., 1946 a, pág. 934.

(53) Ortiz. The Modern Quillacinga, Pasto, and Coaiquer. En Handbook of South American Indians. Vol. II, 1946, pág. 968. 
de la gran familia lingüística Chibcha" (54). Esto nos lo confirma el mismo Padre Rocheraux (55) en su trabajo sobre los Tunebos. El profesor Rivet por su parte tiene un trabajo anterior, que se refiere a esta lengua, en el cual confirma las observaciones anteriores (56).

En lo referente a nuestro estudio tenemos datos fidedignos del uso de la coca con cal entre este grupo. Es el mismo Padre Rocheraux quien nos da valiosos informes sobre la existencia de este elemento en dichas tribus (57).

Para la localización del "habitat" Tunebo en los primeros años del siglo actual, basta mirar el mapa que en la obra anteriormente citada de Rivet, se reproduce. Según este mapa las tribus Tunebo, ocupaban el territorio comprendido entre los cinco grados y siete de latitud Norte y los setenta y tres y setenta y dos de longitud Este del Meridiano de Greenwich (58). Parece que en los tiempos actuales estas tribus han emigrado, unas hacia Venezuela y otras a varios sitios de la Comisaría de Arauca, lo evidente es que hoy se encuentran muy pocos representantes de este grupo.

En la parte septentrional del Departamento de Santander del Sur, hallamos en tiempos de conquista al grupo de los Guane, que pertenecen cultural y lingüisticamente al conjunto de las tribus Chibcha. Con este motivo mencionamos el trabajo de Edith Jiménez (59), quien da noticias de algunos cronistas afirmando esta teoría y presenta un mapa en el cual muestra la situación geográfica del grupo Guane en esas épocas. El mismo autor nos habla del uso que de la coca hacían estas tribus, confirmando aún más la universalidad del empleo de esta planta por las tribus pertenecientes al grupo cultural Chibcha.

Vamos a estudiar la emigración hacia el Norte de Colombia de los Chibchas. La rama Norte de estas tribus es considerada como la más antigua y por lo tanto la primera en penetrar al territorio colombiano. Las principales tribus de esta emigración

(54) Rivet y Oppenheim. La Lengua Tunebo. En Revista del Instituto Etnológico. Vol. I. Entrega 1 ${ }^{a}$, pág. 47.

(55) Rocheraux. Les Indiens Tunebos et Pedrazas. En Journal des Americanistes. T, XI, 1919 , pp. 513-524.

(56) Rivet. Op cit., 1942 a, pp. 19.91.

(57) Rocheraux, Op. cit., p. 521.

(58) Rivet, Op. cit., 1924 b, p. 21.

(59) Jiménez. Los Guane. En Boletín de Arqueologia No 3. 1945, pp. 249-255. 
son los Kógi, los Ika y los Sanká, quienes viven actualmente en la Sierra Nevada de Santa Marta. Existió también una cuarta tribu, los Kankuáma, pero estos se pueden considerar como extinguidos. Dichas tribus hablan dialectos distintos, pero pertenecientes a una misma familia, la Chibcha, y han sido clasificados dentro de ella por Brinton y Rivet. Forman por otra parte una cultura homogénea que se podría considerar como Chibcha por ciertas características. Considerados físicamente los Kógi, Sanká y Kankuáma, forman un tipo somático bien diferente de los Ika, quienes tienen una estatura más alta y facciones más alargadas y finas.

Las mencionadas tribus se conocen bajo el nombre genérico de Aruacos o Arhuacos, denominación que ha dado motivo a muchas equivocaciones ya que han sido confundidos con el nombre de la familia lingüística Arawak. A este respecto nos da la siguiente aclaración el doctor Gerardo Reichel-Delmatoff, de quien he tomado la mayoría de estos datos: "En efecto, los indios de la Sierra Nevada no usan este nombre, ni se designan a ellos mismos o a sus vecinos como Aruacos y consideran esta palabra como término español y no indígena. El origen de este nombre "aruaco", que aplicaron los cronistas españoles ya desde principios del siglo XVII a las tribus de la Sierra Nevada, es un tanto obscuro pero se deriva probablemente de ciertas regiones en las faldas septentrionales". (60). Por esto sería mejor designar dichas tribus con los nombres anteriormente mencionados, para evitar malas interpretaciones.

Por cuanto atañe a nuestro estudio es curioso observar cómo ha persistido el uso de la coca en la Sierra Nevada desde tiempos de la Conquista y quizá anteriormente como lo veremos en el curso de este trabajo. Por el momento vamos a relacionar esta cultura con la de los Tairona que habitaban la región del valle del río Don Diego y la de Santa Marta, limitada ésta hacia el Este por el río Guachaca y hacia el Sur por el río Frío (61).

Las relaciones culturales entre el grupo Tairona y los restantes grupos de la Sierra Nevada, fueron estudiadas por Reichel, quien escribe a este respecto: "Así, pues, parece demostrado por medio

(60) Reichel-Dolmatoff. Los Kógi. En Revista del Instituto Etnológico Nacional. Vol. IV. Entregas $1^{\mathrm{a}}$ y $2^{\mathrm{a}} 1949-1950$, p. 25.

(61) Reichel-Dolmatoff. Contactos y Cambios Culturales en la Sierra Nevada de Santa Marta. En Revista Colombiana de Antropología. Segunda época. Vol. I. No 1. 1953, p. 20. 
de la arqueología, que la cultura de los actuales Kógi, es la continuación de muchos rasgos Tairona a través de quinientos años".

Son muchas las relaciones que se han hallado entre estas culturas por medio de la arqueología pero para nuestro estudio vamos a mostrar únicamente algunos rasgos referentes al uso de la coca. Encontramos en primer lugar el hallazgo de cerámica ceremonial, en especial el de ollas de dobles asas opuestas usadas para tostar hojas de coca, idénticas en su forma y uso a las empleadas por los actuales Kógi. También encontramos máscaras talladas en piedra, análogas a las máscaras ceremoniales talladas en madera, usadas por los Kógi y que son representaciones del acto de masticar coca (62). Observamos además la similitud lingüística de la palabra "hayo" que es la misma dada por los Kógi a la coca, según el estudio de algunas palabras del idioma Tairona, dejadas por los cronistas (63).

Por otra parte Reichel hace un recuento de las manifestaciones culturales de las culturas indígenas de esta región, distinguiendo el grupo del litoral de cultura diferente del de la Sierra Nevada al cual pertenecen los Tairona y las actuales tribus de la Sierra, y encuentra que desde el siglo XVI hasta los tiempos modernos, el consumo de la coca se conserva inalterable en este grupo (64). Estos datos nos revelan la supervivencia de esta costumbre a través del tiempo, seguramente por medio de la religión, ya que esta institución es la que se mantiene más firme en la actualidad, razón elocuente que nos prueba que el uso de la coca es algo fuertemente arraigado en ciertas culturas indígenas y que el carácter eminentemente religioso que tiene se valora mucho más que otras consideraciones de orden económico.

Descrita la relación existente entre las tribus que habitan actualmente la Sierra Nevada de Santa Marta, en las que se encuentra el empleo de la coca, con la cultura Tairona, nos queda aún una incógnita por resolver y la más importante de todas. De dónde procedieron estos grupos de quienes nos hablan los cronistas por una parte y por otra los mismos indígenas actuales en sus mitos y leyendas. Sabemos que históricamente los Tairona, habitaron en el siglo XVI el valle del río Don Diego y las hoyas de los ríos vecinos al Este y al Oeste de él, representados por los Tairo, quie-

(62) Reichel-Dolmatoff. Op. cit., 1953 a, pp. 40 y 44.

(63) Ibid, p. 55.

(64) Ibid, pp. 58, 62, 63 y 73. 
nes se hallaron en relación con los Kógi, pero cuyos antecesores debieron ser los creadores en esta zona de una cultura más elevada. Aunque por el momento no nos permita la arqueología de esta zona determinar claramente un complejo cultural prehistórico, el estudio de los estratos más antiguos nos pone en relación con hallazgos hechos en culturas centroamericanas, de tal manera que debemos presuponer basándonos en esta relación arqueológica, un origen centroamericano para esta cultura de carácter lítico. Ahora bien, dentro del cuadro cronológico general para las culturas americanas, esta cultura sería pre-chibcha y la existencia en ella del uso de la coca denotaría un conocimiento previo de la planta en la región antes de la llegada de los pueblos Chibcha. Algunos autores, entre ellos Krieckeberg y Brinton, clasifican los Tairona dentro de la cultura Chibcha, si bien esta afirmación no tiene mayor fundamento. Pero el caso es que sea chib. cha o pre-chibcha este grupo Tairona, debemos suponer su proveniencia de Centro América, pues en otra forma no podemos admitir la existencia de gran número de elementos de cultura material centroamericanos en los restos arqueológicos de esta cultura, elementos que por su gran número no se pueden atribuír a intercambio comercial. Entre estos elementos figura la coca, a la cual van asociados objetos ceremoniales que supone usos mágicos o religiosos de ella, como lo evidencia su supervivencia a través de varios siglos, entre las tribus que actualmente pueblan la Sierra Nevada.

Es un hecho probado por la historia y la arqueología que el grupo Tairona es anterior a los grupos Kógi, Ika y Sanká, y es también algo evidente la relación cultural existente entre estos grupos y la cultura Tairona. Así nos lo dice Reichel: "Como se observa, existen paralelos bien definidos entre la cultura indígena del siglo XVI y la de las tribus actuales de la Sierra Nevada, y de ningún modo encontramos contradicciones entre las descrip. ciones de la cultura de entonces y la de hoy día" (65). Por lo tanto comprobado este parentesco cultural, debemos pensar si realmen. te vino esta costumbre de Centro América. Las relaciones arqueo. lógicas nos dan pruebas bastante concluyentes como para permitirnos lanzar esta hipótesis.

Hemos visto a grandes rasgos, cómo la coca fue llevada del Perú pre-incaico hasta el Ecuador en épocas precolombinas y

(65) Reichel-Dolmatoff, 1953 b, p. 47. 
luego pasó a Centro América mediante las relaciones comerciales de las culturas centroamericanas, especialmente de Nicaragua y Panamá, con el Ecuador y el Perú, mucho antes del Descubrimiento, como lo aseguran los cronistas y lo revela la arqueología comparada de estas zonas. Después vimos cómo comenzó la mi. gración Chibcha desde Centro América, dos o tres siglos antes de la Conquista, por medio de tres ramas migratorias: una hacia el Oeste y Sur de Colombia, hasta llegar al Ecuador (Barbacoas) donde deja rastros evidentes que atestiguan su llegada a esta región. Otra hacia el Noroeste con centros bien conocidos en el Departamento del Magdalena, y finalmente otra hacia el Centro y Sur, con núcleos bien diferenciados en los Departamentos de Boyacá, Cundinamarca, Tolima, Huila, Cauca y Nariño. Hemos observado a través de nuestro estudio que la coca parece identificarse con la cultura Chibcha y que con manifestaciones en las cuales predomina el elemento religioso, la encontramos en las diferentes zonas correspondientes a esta cultura. También hemos observado que otros grupos anteriores al Chibcha, tales como el Arawak y el Karib, no parecen haber tenido este elemento en tiem. pos precolombinos, ya que en época de conquista solamente contadas tribus, pertenecientes presumiblemente a estos grupos, lo tuvieron y en la actualidad ya lo han perdido o lo obtuvieron por contacto con los Chibcha. Vamos a ocuparnos en seguida de estos y de la importancia que tuvo entre ellos la coca.

Vamos a iniciar el estudio de los mencionados grupos con el de los Guagiros, entre los cuales, según algunos escritos, se usaba la coca en tiempos de conquista. En realidad las noticias historiales a este respecto no son muy numerosas y mucho menos precisas; por otra parte, algunos de sus autores no se consideran como muy dignos de crédito, puesto que escribieron basándose en crónicas anteriores y llenando de fantasía sus relatos. Entre ellos está el Alférez José Nicolás de la Rosa, quien al hablar del grupo que él considera guagiro, escribe lo siguiente: "Tienen también el vicio del hayo y manejo del poporo como los arhuacos" (66), con lo cual nos da a entender que existían ciertas relaciones entre la Guajira y la Sierra Nevada, caso muy posible, pues se han encontrado sitios de contacto comercial en los límites del Departamento del Magdalena con la Comisaría de la Gua-

(66) De la Rosa. Floresta de la Santa Iglesia Catedral de la Ciudad de Santa Marta, 1945, pág. 279. 
jira. Mucho más abundante, pero no por ello menos obscura, es la noticia que nos da don Antonio Julián, quien escribe un capítulo bastante extenso, en el cual nos habla del uso que de la coca hacían los indígenas del Nuevo Mundo y en especial los Guajiro, con una serie de consideraciones de índole muy personal sobre las cualidades y uso de la planta. Por ser muy abundante la noticia no me referiré a toda ella y únicamente citaré unos cuantos apartes. Se refiere principalmente a los Guajiros y sobre ellos escribe lo siguiente: "Los indios Guajiros la usan casi continuamente, noche y día, mascando las hojas no tostadas ni secas, sino frescas, verdes y hermosas, chupando y enviando al estómago todo el jugo de ellas..." (67) Hay un marcado contraste entre esta nota y la del Alférez de la Rosa, pues mientras don Antonio asegura que usaban de las hojas verdes y frescas, el segundo da a entender que su uso era el mismo de los indios de la Sierra Nevada, es decir, acompañándola de cal; y más adelante dice este autor conocer la existencia de los indios de la Sierra, pero negando que ellos consumieran la coca, pues asegura que "sólo los Guajiros comen y usan el hayo y sólo los Guajiros son los de bella presencia" (68), atribuyendo a las cualidades de la hoja la robustez y buena apariencia física de este grupo. De esto debemos deducir que o no conocía personalmente las tribus de la Sierra o no tomó buenos informes de ellas, ya que escribe esta crónica en el siglo XVIII y ya sabemos del uso de la coca por estos indios en esa época, o bien quiere dar con ello mayor énfasis a su afirmación, de que es por causa de dicha hierba que los Guajiros se conservan sanos y robustos. Cualquiera de estas afirmaciones acusa una gran ignorancia de los hechos ocurridos en el Nuevo Reino de Granada, ya que en este tiempo era muy conocida la coca en diversas tribus.

En resumen, la noticia que nos da don Antonio Julián, muy laudatoria de los buenos efectos que produce la coca, no nos dice nada en firme sobre su uso entre las tribus que habitaban en esa época el Nuevo Reino de Granada. Lo evidente es que si existió esta costumbre en la Guajira como aseguran los cronistas, ésta no prosperó, ya sea porque las continuas sequías no permitían el cultivo intensivo de la planta o porque no siendo herencia

(67) Julián. La Perla de América y Provincia de Santa Marta. Discurso VII.

(68) Ibid. Discurso VII. 
cultural, fue fácilmente abandonada y no se conserva actual. mente entre esas tribus.

Otro grupo ya no Arawak, como los Guajiros, sino Karib, el de los Motilones de la Serranía de Perijá en los límites con Venezuela y precisamente el más septentrional de ellos, según el Marqués de Wavrin (69), usaron la coca hasta hace poco tiempo, pero esto se debe según mi parecer, a las relaciones comerciales con los indios de la Sierra Nevada, puesto que se han encontrado sitios de contacto entre estos grupos, que datan de tiempos muy antiguos y es curioso observar cómo precisamente la tribu que se encuentra más cerca del Departamento del Magdalena, sea la única entre los Motilones que tiene este uso, aunque hoy día casi desaparecido, pues estos grupos son sobre todo fumadores de tabaco en pipa.

Mirando ahora hacia el Oeste de Colombia, encontramos en la ribera derecha del río Cauca, entre sus afluentes los ríos Otún y Paila y en los correspondientes al Suroeste del actual Departamento de Caldas y al Noroeste del actual Departamento del Valle, al grupo de los Quimbaya, que han sido clasificados por Rivet dentro del grupo Karib. Estas tribus según Gregorio Hernández de Alba (70), cultivaban y usaban la coca en la época de la Conquista. No sabemos con certeza si la adquirieron por comercio con los Cuna o con otro grupo Chibcha. Lo evidente es que, tanto estos como sus vecinos los Anserma y los Lilí, conocieron y usaron la coca durante la época de Conquista, como lo afirman los cronistas. Parece que la influencia Chibcha, se extendió por el Oeste colombiano, llevando naturalmente el uso de la coca.

En las regiones del Vaupés, Caquetá y Amazonas, existen actualmente tribus indígenas que pertenecen a diversas familias lingüísticas y entre las cuales se encuentra difundido el empleo de la coca. La adquisición de este elemento por tales tribus, parece de más reciente data, por lo tanto no entraremos a estudiar estas tribus sino más adelante, cuando hablemos de la distribución actual de la coca entre las tribus indígenas de Colombia.

Hasta aquí hemos hablado del origen de la costumbre de mas. ticar la coca y su posible difusión a través del territorio colom-

(69) Wavrin. Mours et costumes des indiens sauvages del Amerique du Sud, pp, 61 y 153 .

(70) Hernández de Alba. Sub-Andean Tribes of de Cauca Valley. En Handbook of South American Indians. Vol. IV, 1948, p. 313. 
biano gracias a tribus de cultura y lengua Chibcha. En el mapa No 1 , hemos señalado por medio de flechas los distintos movimientos migratorios que acompañaron la difusión de la planta, desde el Perú y Ecuador hasta la América Central y desde esta a través del territorio de Colombia. En la misma forma se ha señalado una posible influencia pre-incaica en la región de San Agustín.

\section{DISTRIBUCION DE LA COCA ENTRE LAS TRIBUS INDIGE.} NAS QUE HABITAN EL TERRITORIO COLOMBIANO.

Iniciaremos esta parte de nuestro estudio, con las tribus que habitan el Norte del País. En el Departamento del Magdalena y más exactamente en las estribaciones de la Sierra Nevada de Santa Marta, viven actualmente tres grupos indígenas, que pertenecen a una misma cultura y hablan una misma lengua. En el momento presente, su lengua nos permite clasificarlos dentro de la familia Chibcha. Estos grupos son: los Kogi, los Ika y Sanká, quienes con algunas diferencias dialéctales y físicas, pertenecen a un mismo conjunto cultural.

Los Kogi, el principal de estos grupos y el mejor estudiado, habita en las faldas septentrionales de la Sierra Nevada, ocupando los valles de los ríos Palomino, San Miguel y Ancho. Existe un pequeño grupo que vive en el alto río Don Diego y otro en las ca. beceras del río Ranchería. Los Ika viven en las faldas sud-occidentales y en el curso de los ríos que bajan hacia el Occidente. Su principal población es San Sebastián de Rábago en el alto río Fundación y algunos grupos pequeños vienen en el curso del río Sevilla. Los Sanká viven en las cabeceras del río César en el Ce. rro, Cerrito, Potrero y Potrerito, en caseríos muy dispersos y ocupan en parte las poblaciones Kógi de Surlibáka y Banáka en las cabeceras del río Ranchería (1).

Estos grupos tienen la costumbre de masticar coca con cal y zumo de tabaco, hecho que debemos resaltar, ya que la adición de otro alcaloide al de la coca, debe producir en el individuo efectos narcóticos de gran intensidad que deben ser perjudiciales. Es evidente que esta costumbre es una supervivencia cultural a través de varias centurias, como lo comprueba la arqueología

(1) Reichel-Dolmatoff. Op. Cit, 1949-1950 a, pp. 27 a 30. 


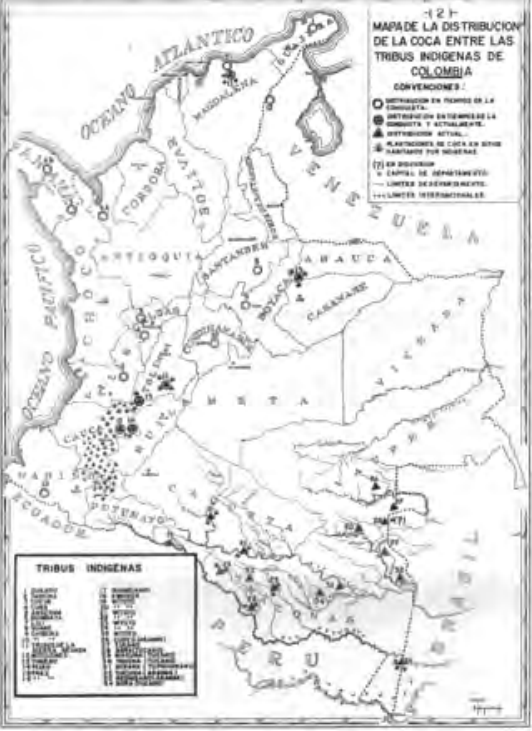


de la región, costumbre acentuada hoy por el ambiente míticoreligioso en que se mueve esta cultura.

Si recorremos el territorio colombiano de Norte a Sur y propiamente la zona andina, veremos que la cosa se cultiva desde el Departamento del Magdalena hasta el de Nariño, y que la consumen además de los indígenas, algunos mestizos en número muy inferior al de los primeros, a quienes se debe especialment su cultivo y consumo. Vamos a señalar algunos de estos grupos e indicar su localización en el mapa de Colombia.

En el centro del Departamento del Tolima, se encuentra un grupo Pijao, sobreviviente de aquellas afamadas tribus que tuvieron en jaque a los españoles durante la conquista y la colonia. El descubrimiento de este grupo para la ciencia, se debe al Etnólogo Gerardo Reichel-Dolmatoff y a su esposa Alicia Dussán de Reichel, quienes lo visitaron a mediados del año de 1943, rea. lizando en él, importantes investigaciones antropológicas. Aurque ya bastante aculturados, conservan no obstante, restos de su cultura material y espiritual. La clasificación lingüística del grupo Pijao corresponde a la familia Karib y aunque ha sido muy discutida esta clasificación del Profesor Rivet, la aceptaremos como la más probable. En cuanto a la cultura, no sabemos aún a qué grupo cultural pertenezcan y esperamos que los datos antropológicos obtenidos en este grupo del Tolima, ayuden a esclarecerlo.

Los Pijao encontrados por el doctor Reichel, comprenden tres grupos: el primero se encuentra en la parte montañosa de la cordillera de Calarma, las cabeceras de los ríos Loaní y Toy, el segundo en la planicie, entre la cordillera de Calarma y los cerros que la limitan hacia el río Saldaña y el tercero en la región ribereña del río Saldaña. Etnicamente los tres grupos representan una sola unidad (2).

Entre estos Pijao, según referencias personales del doctor Reichel, se encuentra el cultivo y uso de la coca, en forma análoga a la de los grupos Páez vecinos. Debido a la ausencia de este elemento y dada la circunstancia de que este grupo es presumiblemente Karib, podemos pensar que esta costumbre fue tomada por contacto con grupos Páez, quienes fueron sus vecinos desde tiempos de conquista y probablemente el uso de la coca se extienda

(2) Reichel-Dolmatoff. Grupos Sangíneos entre los indios Pijao del Tolilima. En Revista del Instituto Etnológico Nacional. Vol. I. Entregas $1^{\mathrm{a}}$ y $2^{\mathrm{a}}, 1944$, p. 507. 
hasta esta época entre los grupos Pijao como lo dan a entender los cronistas.

Al Sur del Departamento del Tolima y entre los ríos Atá y Saldaña, se encuentra actualmente un grupo Páez. Entre ellos, como entre sus vecinos los Paeces de Tierradentro se encuentra generalizado el empleo de la coca. Este dato lo obtuve también del doctor Reichel, quien visitó este grupo Páez, en su viaje al Tolima en el año de 1943.

Es sobre el grupo Páez de Tierradentro que me detendré un poco más, por la circunstancia de ser este el principal centro de cultivo y masticación de la hoja de coca entre grupos indígenas colombianos y mi permanencia en dicha región durante los primeros meses del año próximo pasado, me permiten dar noticía fiel sobre este hecho.

Sobre los Paeces de Tierradentro han escrito varios investigadores, entre ellos los etnólogos José Pérez de Barradas y Gregorio Hernández de Alba (véase bibliografía), pero a pesar de que sus observaciones sobre estos indios son muy valiosas y acertadas, no se detienen mayormente en sus referencias al uso de la coea. Ambos están de acuerdo en que la usan los hombres, mujeres y niños desde temprana edad y que hace parte en el ceremonial del médico Páez. Muy poco se nos dice sobre el cultivo de la planta y su participación en la cultura del grupo estudiado; más adelante tendré ocasión de extenderme sobre ello, más por el momento bastan unas pocas observaciones.

El núcleo Páez de Tierradentro es bastante numeroso si lo comparamos con otros grupos indígenas de la nación, un cálculo aproximado nos da la cifra de 30.000 individuos, que viven al Noroeste del Cauca entre los 75 y 77 grados de longitud Oeste y los 2 y 3 grados de latitud Norte. Estos indios cultivan y consumen la coca desde hace más de cuatro siglos, encontrándose sus cultivos en los valles atravesados en su mayor parte por el río Páez y que se extienden hasta unos 2.000 metros sobre el nivel del mar. Se siembra coca, por lo general entre los cultivos de café, plátano y caña de azúcar. La coca tiene entre los Paeces el carácter de un substituto alimenticio, pues se consume con el objeto de aplacar el hombre en los horas de trabajo y también se utiliza en las ceremonias mágicas, tales como la adivinación y la limpieza de alguna familia con ocasión de la muerte de un pariente. El consumo de la planta lo hacen todos los individuos del grupo, hombres, mujeres y niños desde temprana edad y se 
comercia con ella activamente, sirviendo de moneda en sus transacciones.

Los Paeces de Tierradentro se dividen en tribus, cada una de las cuales integran una de las 20 parcialidades en que se divide la región, pero salvo algunas diferencias dialectales, todas pertenecen a una misma cultura. Sin embargo la extensión del grupo Páez es mucho mayor y pasa los límites de Tierradentro, extendiéndose por los Departamentos de Cauca, Tolima y Huila en la forma siguiente: Por toda la hoya del río Páez y sus afluentes (núcleo principal); en el plano Oriental de la Cordillera Central y en el Occidental de la misma; las cabeceras de los ríos Ovejas, Mondomo, Isabelilla, el Palo y sus afluentes superiores, entre los cuales están las poblaciones de Pitayó, Jambaló, San Francisco, Toribio, Tacueyó y Quichaya con caseríos en sus alrededores; las cabeceras del río Quilichao y Jebalá en la margen izquierda del río Piendamó. En el plano oriental de la Cordillera Occidental, en las cabeceras de los ríos Inguitó y Dinde hasta el cerro de Muchique, que forma las poblaciones y caserios de Chimborazo, El Mesón, San Joaquín y Muchique. Además el núcleo descubierto en el Tolima por el Etnólogo Reichel de que ya hicimos mención. En total una población que alcanza según mis cálculos a unos cincuenta mil individuos, número bastante considerable y digno de tenerse en cuenta. Estos núcleos tienen gobierno propio y pertenecen con algunas variedades dialectales a la cultura Páez. Todos ellos tienen la costumbre de masticar la hojas de coca, que se cultiva con mayor o menor intensidad, de tal modo que es muy importante tener en cuenta este grupo, para comprender la magnitud del problema alimenticio por el cual atraviesa la población indígena de Colombia.

En el Departamento del Cauca se encuentra también el grupo de los Guambianos cuya extensión y población es más o menos la siguiente: Toda la hoya del río Piendamó, la parte superior del río Cofre, la población de Totoró en sus alrededores, la parcialidad de Guambía al Oriente de la población de Silvia, la de Quizgó al Norte de la misma y la antigua parcialidad de Ambaló hoy día propiedad particular, al Sur. Los indígenas que viven en dichos territorios suman unos siete mil, correspondiendo cuatro mil quinientos a la parcialidad de Guambía, dos mil a la de Quizgó y quinientos aproximadamente a los restantes sitios. Entre estos indígenas se consumía la coca con cal, pero últimamente, bien por el mejoramiento de sus medios de subsistencia 
o por la dificultad de conseguir la hoja que no se produce en Ia región, el consumo de esta planta se ha relegado a la población de ancianos y a los médicos quienes la usan en sus prácticas mágicas; esto en las parcialidades de Guambía y Quizgó, porque en la región de Ambaló, los individuos viven sometidos al blanco, quien les da trabajo en sus propiedades y estos sí mastican la coca en las horas de labor para soportar la fatiga y el hambre, pero aún entre estos ha disminuído mucho su consumo por la dificultad en conseguirla y el alto precio que tiene ahora la hoja, precio con el cual se benefician los blancos que son los que la venden ya sea en los sembrados de su propiedad o por medio del contrabando. Por eso no me parece una medida acertada para acabar con el consumo de la coca, el destruir las plantaciones que de esta tienen los indígenas, pues con esto sólo consiguen encarecer el producto y fomentar el contrabando. Lo acertado sería a mi modo de ver, mejorar las condiciones de vida, por medio de la educación y la higiene, incrementando los medios de producción, enseñándole al indígena por medios pacíficos que no sólo de la hoja puede derivar la energía suficiente para el trabajo y dándole medios naturales y artificiales para defenderse de las enfermedades que minan la salud; prohibien. do la venta de licores oficiales en las vecindades de las parcialidades indígenas, ya que esto no vendría a establecer una "ley seca" entre los indígenas, puesto que ellos tienen al guarapo que suple perfectamente el consumo de licores tóxicos, a que no están acostumbrados los organismos de estos indios.

La tribu Guambiano, pertenece al grupo lingüístico Kokonuko y en su lengua se encuentra una palabra especial para designar la coca; es muy posible que este uso se extienda a todo el grupo, ya que el hábito sobrevive en varios de los sitios ocupados por él. Efectivamente el empleo de la coca se halla muy extendido por el Departamento del Cauca, pues además de los sitios ocupados por los Paeces, existe en los alrededores de las poblaciones caucanas de Piendamó, Silvia, Popayán, Timbío, Cajibío, El Bordo, La Vega, Almaguer y Bolívar, sitio de habitación de indí. genas más o menos mestizados y aculturados que pertenecen al grupo Kokonuko, como he podido constarlo personalmente en parte y como lo confirman varios autores, entre ellos Miguel de Garganta Fábregas (3).

(3) De Garganta Fabregas. Noticia sobre la coca en el Occidente Colombiano. En Revista de Historia de Pasto. Nọ 2, págs. 215-232. 
Por su parte, don Tiberio López me aseguró que en las poblaciones caucanas de Río Blanco, Guachicono y Pancitará, vive un grupo indígena quien consume la coca, pero que vive al parecer en óptimas condiciones físicas. También el Etnólogo Mil. cíades Chaves, asegura que los indios de Santa Rosa (Cauca) mastican la coca y que los habitantes de Descanse (Cauca) y Yunguillo (Putumayo), cultivan la planta con fines comerciales (4).

Respecto al Departamento de Nariño, me refería en el capítulo V de este trabajo al escrito del doctor Sergio Elías Ortiz, sobre los Koaiker, que aparece en el Vol. II del Hand Book of South American Indians y en el cual dice que aún se conserva entre los koaikeres el uso de la coca y según informes obtenidos personalmente de este distinguido investigador, dicho escrito es el resumen de un trabajo que fue publicado en la Revista Idearium, órgano de la Escuela Normal de Occidente, con el título de "Notas sobre los indios koaikeres". En este trabajo nos dice Ortiz, que: "Hoy mismo, en lo más intrincado de la montaña, los viajeros encuentran koaikeres que llevan colgadas del cuello dos jigras chepas mochilas gemelas tejidas de cabuya) que contienen la una cal y la otra cosa (5). A pesar de esta información, obtenida sin lugar a dudas de algún viajero que pasó por tierras de los koaikeres, yo debo permitirme dudar si no de la veracidad de ella, de la apreciación de la misma, pues seguramente a quienes vio este viajero fue a algún indio o indios cayapas, procedentes del Ecuador donde aún conservan esta costumbre, pero no pudo haber visto ningún koaiker, pues entre estos ni se culti. va, ni se consume la coca y mucho menos se tejen mochilas de la clase que describe el autor. Posiblemente esta costumbre desapareció por causas desconocidas entre estos indígenas, de cuya historia hace parte como lo dice Gregorio Hernández de Alba y lo asegura el mismo 0rtiz. Esta corrección la hago poco después de mi permanencia entre los indios koaikeres del Sur de Nariño, entre quienes obtuve estos datos.

Por el contrario, al Norte del mismo Departamento de Nariño y en la población denominada la Cruz viven grupos de indios y mestizos que cultivan y mastican las hojas de coca, uso que no

(4) Citado por Luis Duque Gómez en Notas sobre el Cocaísmo en Colombia. En Boletín de Árqueología No 4. p. 448.

(5) Ortiz. Notas sobre los Indios Koaikeres. Revista Idearium. Organo de la Escuela Normal de Occidente. No 1. Pasto 1937. pág. 27. 
se sabe si lo tienen desde tiempos anteriores a la conquista o fue llevado por los Incas, quienes alcanzaron en sus conquistas esta región, según nos lo dice Ortiz en la nota siguiente: "Existió al lado del río Mayo, cerca del sitio donde se fundó posteriormen. te La Cruz, el pueblo llamado Chincha, el único territorio de Pastos y Quillacingas que conservó por el nombre el sabor de las denominaciones geográficas de los Incas, como recuerdo quizá del nombre de las islas chinchas y más probablemente de una de las grandes provincias del Thahuantinsuyu, la llamada Chinchay. suyu. Fue sin lugar a dudas el pueblo de Chincha, la única colonia viva, especie de guarnición, que dejaron los incas conquistadores como la última avanzada de su dominio, porque en esa región (hoy La Cruz), se ha conservado, con mayor abundancia y vigor que en ningún otra parte del Sur de Colombia, las voces incas, ya en su forma primitiva, ya mezcladas con el castellano, lo que han dado en llamar quechuismos. En ninguna otra parte se advierten de manera tan marcada como en La Cruz, no sólo la influencia de la lengua inga, sino las características raciales de los indios que aún existen allí con contaminación con la raza blanca" (6).

Parace pues evidente la existencia prehistórica de la coca en el Departamento de Nariño ya sea como costumbre propia de los indios que lo habitaban antes de la Conquista o por influencia de las culturas peruanas y es evidente también la existencia del cocaísmo en la actualidad. Sobre hallazgos que presumiblemente podemos tener por prehistóricos, podemos citar el de una estatua de piedra, encontrada en el campo de deportes de la Normal de Occidente por Sergio Elías Ortiz, la cual tiene rasgos muy acusados del mascador de coca (7). Esta estatua y la encontrada en la región de San Agustín guardan una gran relación y pertenecen como ha hemos dicho, probablemente a una de las grandes culturas preincaicas. Sobre dicha pieza arqueológica habla también el señor de Garganta (8) quien tuvo también oportunidad de verla.

(6) Ortiz. Informe sobre la Prehistoria del Departamento de Nariño. Boletín de Estudios Históricos. Vol. V. N⿳亠 V. 54. Pasto 1934, p. 186.

(7) Ortiz. Excavaciones arqueológicas en el campo de la Aurora. Revista Idearium. Organo de la Escuela Normal de Occidente. Año $1^{0} \mathrm{~N}^{0} 1$. Pasto. 1949, p. 49.

(8) De Garganta Fábregas. Op. Cit, p. y citada también por Pérez de Barradas. Op. Cit. 1940 h, p. 323. 
Lo que parece a todas luces claro es que ya en el siglo XVI, la coca era artículo de regalo muy apreciado en Nariño ya que figura en documentos de esa época con bastante claridad, como podremos juzgarlo en la siguiente nota, que se refiere a la donación que hace el Convento de Santo Domingo al Monasterio de Monjas de la Concepción de Pasto: "El Prior y el Convento de Santo Domingo dan por el apartamiento de dicho y hacen graciosa donación a este convento de Monjas de unas "chácaras de coca" para siempre jamás que son las que dicho convento de Santo Domingo tenía y poseía en tierras de Sandoná a orillas del río grande que dicen Guaitará... y Bartolomé Chamorro demás de los dichos cocales que el dicho convento de Santo Domingo traspasa para siempre jamás a este convento de Monjas trescientos pesos de buen oro de veinte quilates cada peso..." (9). Este documento es de 1590 y parece que los cocales de que habla son mucho más antiguos, de donde podemos deducir que la coca era bien conocida en Nariño por esta época.

En nuestras intendencias y comisarías, viven numerosas tribus indígenas que han sido clasificadas provisionalmente dentro de ciertas familias lingüísticas, pero cuya cultura está lejos de ser bien determinada. Entre algunas de estas tribus existe el háphito de la coca, con características regionales que hacen suponer que este hábito no es muy antiguo y seguramente fue obtenido de las tribus andinas, por comercio a lo largo de los grandes ríos; lo evidente es que se encuentra en las zonas de fácil transporte fluvial y entre tribus que realizan su intercambio comercial por esta vía.

En el Vaupés se encuentra entre los Cubeo o Kobeua del río Vaupés y su afluente el Cubiyú, quienes pertenecen a la familia lingüística Arawak; entre los Tukano, en la parte baja del río Vaupés; en los Bará, en las fuentes del río Tiquié (10) que pertenecen a la familia lingüística Tukano *, y a orillas del río Apa-

(9) Ortiz. El Monasterio de las Monjas de la Concepción de Pasto. Boletín de Estudios Históricos. Vol. $1^{9} \mathrm{~N}^{\mathbf{0}}$ 29. Pasto 1930, p. 144.

(10) Koch-Grümber. Zwei Jahre bei don Indianer Nordwest Brasiliens. Stuttgart. 1923, pp. 174, 175, 273, 384.

* Según el Etnólogo Marcos Fülop, quien regresó hace poco tiempo del Vaupés, en las fuentes del río Tiquié se encuentra el grupo de los Varasanas, quienes sí pertenecen a la Familia Tucano. Por el contrario los Bará o Baré que cita Koch-Grümber, se encuentran en el medio río Apaporis y pertenecen a la Familia Tupi-guarani. Estos grupos tienen el hábito de la coca. 
poris, un poco abajo de la desembocadura del Piraparaná, en tribus Makuna (Tukano) (11).

En el Amazonas se halla en las tribus: Rosíggaro (Arawak), Yukuna (Arawak) y Miraña (Tupiguarani) (12); entre los Yahuna (Tucano), que viven en la parte central del Apaporis, un poco arriba de la desembocadura del Piraparaná (13); y finalmente entre los Witoto, cuyo habitat hemos podido definir muy difícilmente, pues se trata de tribus dispersas por casi todo el Amazonas y parte del Caquetá y en los escritos sobre este grupo los datos al respecto son muy diversos. Murdock, por ejemplo, sitúa a los Witoto, entre los ríos Yapurá y Putumayo, de los 73 y 75 grados de longitud Oeste a los 9 y 2 grados de latitud Sur (14), mientras que Koch-Grumberg, les da como límite, las regiones comprendidas entre el Alto Yapurá y el Ica y especial. mente a los ríos Caraparaná e Igaraparaná, delimitación un poco vaga, pero que corresponde a la realidad de la época (1906), aunque ya para ese tiempo, debido a la persecución empleada por los caucheros contra los indígenas, había comenzado el éxodo de las tribus. Actualmente, quien fijó los límites del habitat actual con bastante exactitud, fue Mons. Pinel y de acuerdo con él po. demos decir que los witotos han ocupado u ocupan los siguientes sitios en los ríos Caquetá y Putumayo y algunos de los afluentes de éstos: Quinoró, Cuemaní, Bocana del Yarí, Araracuara, Güepí, Suncilla, Cahunarí, Comañí, Laguna de Urbano Gutiérrez, La Cucha, Peña Colorada, Los Portales, Laguna de Guaicorá, El Encanto, río Eré, río Algodón, río Menaje, río Canioni, etc.; se los encuentra también, en pequeños grupos, en sitios muy apartados de su residencia habitual, río Negro, Mitiparaná, Apaporis, Napo, etc." (15). En realidad actualmente los Witoto se encuentran localizados en diversas localidades del Amazonas, el Sur y el Oeste del Putumayo y el Sur del Caquetá *. En todos estos sitios, se cultiva y se consume la coca, como lo aseguran los autores consultados y lo confirman exploradores y oficiales del ejér-

(11) Informe del Etnólogo Marcos Fulop.

(12) Castellví. Materiales Etnobotánicos sobre el Tabaco y la Coca, en Revista Amazonia. Tomo II. Nos. 4-5-6. Sibundoy. 1941-1944, pág. 163.

(13) Informe del Botánico García Barriga.

(14) Murdock. Nuestros Contemporáneos Primitivos. Edic. Fondo de Cultura. Méjico. 1945. p. 375 .

(15) Ortiz. Familia Witoto, en Revista de Historia de Pasto. № 1.942, p. 9.

* El mismo Ortiz, en su obra Lingüística Aborigen de Colombia. Bogotá, 1954, pp. 314-348, nos confirma nuevamente el habitat de los Witoto y presenta nuevos datos. 
cito de Colombia con quienes hemos tenido conversaciones al res. pecto. En el capítulo siguiente daremos a conocer los diversos modos de utilizar la coca entre las diversas tribus colombinas, la forma de cultivo y el factor cultural que condiciona este uso.

En el mapa número 2 que ilustra este trabajo, están señaladas con un círculo las tribus que usaron la coca en tiempos de la Conquista y con un triángulo las que la usan en la actualidad.

\section{VARIACIONES DEL USO DE LA COCA. CULTIVO Y ASPECTO CULTURAL DE ESTE HABITO EN LAS TRIBUS INDIGENAS DE COLOMBIA}

Al hablar de variaciones en el uso de la coca, nos referimos a los diferentes empleos que se dan a la hoja y a los diversos modos de preparación de la misma. En el caso de las tribus andinas, hablamos de su utilización como masticatorio, acompañada de cal y en algunos grupos de zumo de tabaco; pero si se trata de tribus amazónicas, el caso es diferente, pues si bien es cierto que mastican durante algunos minutos la hoja, previamente tostada, pulverizada y mezclada con cenizas de yarumo (cecropia), ésta es tragada luégo lentamente, operación que difiere de la exclusiva masticación de ella por las tribus andinas, y aunque en ambos casos, se persigue igual finalidad, es decir, aplacar el hambre y la fatiga, este efecto es obtenido por medios distintos. Lo evidente es que el acto de masticar la hoja de coca, parece ser el resultado de un elaborado proceso ritual que llegó a las tribus andinas por herencia cultural y en cambio el de ingerir el polvo, obedece a necesidades de orden exclusivamente material. En el primer caso, es cierto que se busca en principio aliviar un problema alimenticio, pero el acto de la masticación está condicionado por un factor religioso y en el segundo este factor no tiene mayor valor, por no haber adquirido estos grupos el uso de la coca por herencia cultural desde tiempos antiguos, a pesar de encontrarse incorporado a su cultura y manifestarse en las ceremonias de carácter mágico de sus médicos, pero este hábito se remonta acaso a unas tres generaciones atrás y no figura en la mítica, exceptuando el caso de los Witoto, entre quienes aparece la coca en los mitos sobre el origen del reino natural, pero aun entre ellos su uso difiere del de las tribus andinas y es probable que en mitos más antiguos no aparezca la coca, pues ésta pudo 
muy bien introducirse recientemente con otras plantas de origen exótico.

Por otra parte, aunque al decir del Etnólogo Marcos Fulop, entre el grupo Tukano, a pesar de la poca variedad en la alimentación y el escaso valor proteico de la misma, no se padece ham. bre, ni se encuentran casos de avitaminosis y raquitismo, si la coca entre ellos no representa el valor de un substituto alimenticio, nos hallamos entonces en presencia de un hábito vicioso, como el tabaco entre nosotros, pero aun en este caso, el fin in. mediato de la ingestión de la coca, debe ser el anestesiar las mucosas y mantener al individuo en un estado de euforia, que él permita cantar, conversar y bailar por largo tiempo, sin sentir hambre ni fatiga y cuando va de viaje soportar las penalidades de éste, es decir que en realidad sí es un valioso substituto, pues en otra forma no se explicaría el empleo de la coca por estos indígenas. Por lo tanto, al tratar de las tribus amazónicas, no podemos hablar de la masticación de la coca, sino de la ingestión de ella. Este caso se debe estudiar detenidamente, no sólo desde los aspectos económico y social, sino también desde el punto de vista médico, pues todas las pruebas hechas en el individuo sobre los efectos de la coca, se refieren únicamente a la masticación y no a la ingestión de ésta, por consiguiente hasta el mo. mento actual no se ha probado que los efectos de la coca así usada, sean más o menos perjudiciales al organismo humano y esperamos que un estudio a fondo de este problema nos responda este interrogante.

$\mathrm{Al}$ iniciar el estudio etnológico de las tribus colombianas entre las que se conoce el uso de la coca, hemos considerado primero a las tribus andinas del Norte y en este caso seguiremos el mismo orden comenzando por los grupos que habitan la Sierra Nevada de Santa Marta. Quien ha estudiado los indígenas de esta región en forma bastante completa y con un criterio científico digno de todo elogio, es el Etnólogo Gerardo Reichel-Dolmatoff, y a él principalmente nos referiremos por ser fuente merecedora de crédito; citaremos además otros autores no menos veraces, pero con menor criterio científico que el anterior.

Ya hemos localizado geográficamente las tribus que habitan la Sierra Nevada y en esta ocasión, únicamente nos referiremos al cultivo de la coca, su forma de uso y la contribución de ella a la cultura de los grupos estudiados. 
Estudiaremos en primer lugar el grupo Kógi, quien ha logrado una gran estructuración en sus instituciones social y religiosa, dándole a la coca una especial significación dentro de ellas, como que sirve de regulador de ciertas tensiones psicológicas, ya que a ella va a desembocar una parte considerable de los efectos de la población masculina.

Empezaremos con algunas consideraciones sobre el cultivo, cosecha, preparación y uso de la coca entre los Kógi, y a este respecto me permito citar fielmente lo escrito por el doctor Reichel, quien dice: "Todos los hombres adultos iniciados mastican las hojas de coca, costumbre que en la cultura Kógi ha tenido gran elaboración. Los cultivos de coca se encuentran al lado de todas las casas o poblaciones donde ocupan el mayor espacio posible y existen también en los cultivos alejados. Las matas se cuidan con mucho esmero y se limpian y podan a cada momento y el terreno se riega con zanjas y canales. Se distinguen tres clases de coca, que "pertenecen" a diferentes tribus: una clase de hojas alargadas (tribu Kamkuáma), otra de hojas pequeñas (tribu Ika) y una tercera, también de hojas pequeñas que se considera como "perteneciente" a los Kógi. Además se dice que en los páramos hay un árbol bastante alto cuyas hojas se parecen a la coca y que se llama guanguára o guanguála. "Los antiguos tenían esta coca", se dice.

$\mathrm{El}$ individuo que quiera sambrar coca debe en primer lugar proveerse de ciertos "permisos" del máma. El mero cuidado de los cultivos de coca y la labor de la tierra representa un trabajo masculino, pero la cosecha de las hojas es una actividad femenina. Tratándose de una planta perenne, las hojas se pueden recoger en cualquiera época del año. Las mujeres las arrancan y las llevan en mochilas grandes a las casas donde los hombres las reciben para su elaboración. Primero se limpian las hojas de insectos y se arrancan los tallos o partes secas y dañadas. Luégo las hojas frescas se ponen en una olla especial provista de dos asas opuestas y utilizada sólo para este fin, y se tuestan ahora dentro de la casa ceremonial sobre un fuego lento. Al mismo tiempo se revuelven continuamente para evitar que se quemen, ya que deben quedar medio secas y de color verde claro, dorado. Luégo se ponen las hojas dentro de una pequeña mochilita de algodón que se guarda dentro de una de las mochilas grandes que lleva el hombre terciadas. Una mochilita llena se consume en uno o en dos días. Para dar la reacción deseada, las hojas 
deben mezclarse con cal. Esto se obtiene quemando conchitas de bivalvos, que se consiguen en las playas del mar, sobre una pequeña pirámide de espartos delgado. Esta cal se recoge luego en un calabacito en forma de botella, de 10-15 centímetros de alto y se extrae de este por medio de un palillo delgado de madera dura, el cual se deja tapando la boca del calabacito cuando éste no está en uso. Primero el hombre toma con la mano derecha unas 50 hojas de la mochilita y las introduce a la boca. Después de haberlas masticado por unos minutos, escupiendo ocasionalmente el jugo verdoso, saca el palillo del calabacito y lo lleva a la boca, chupando ruidosamente la cal adherida al extremo de la madera. Ahora, teniendo el calabacito en la izquierda, coge el palillo a modo de un lápiz pero entre el índice y el dedo del corazón y frota el extremo mojado de saliva alrededor de la abertura del calabacito con el fin de sacar el palillo así. Durante este proceso el palillo se frota rápidamente con movimientos cortos y duros sobre el calabacito, la mano izquierda da lentamente vueltas a éste. Con el tiempo se deposita así alrededor de la abertura del calabacito una capa de cal que se endurece y crece hasta formar un cuerpo de color amarillo. Este se modela con un cuchillo de vez en cuando y forma luégo una especie de cilindro o disco, según el tiempo que el calabacito haya estado en uso. Calabacitos de cal que tengan varios años sin haberse roto, tiene a veces un disco grueso y ancho alrededor de la boca, el cual se recorta y se forma cuidadosamente. Cada 20-30 minutos más o menos, el individuo extrae las hojas masticadas con la mano de su boca e introduce otro tanto de hojas frescas. Las hojas masticadas no se escupen directamente pero durante la masticación se escupe a cada rato el jugo verdoso y amargo (1). De tales palabras deducimos que la siembra, recolección, preparación y uso de la coca, son actividades sumamente importantes dentro del grupo Kógi por el gran cuidado que ponen en ellas; que la coca tiene el carácter de árbol sagrado, ya que para cultivarla se debe pedir permiso al máma o sacerdote; que su uso es constante entre la población masculina, y por último que es el resultado de un elaborado proceso cultural.

Sobre el sexo al cual está reservado el empleo de la coca, sus efectos, racionalización y ceremonias de iniciación de los jóvenes, citaremos nuevamente a Reichel, quien escribe: "Para las

(1) Reichel-Dolmatoff. Op. cit., 1949-1950, b, pp. 75, 76 y 77. 
mujeres Kógi es absolutamente prohibido masticar coca y su uso se empieza obligatoriamente sólo después de la iniciación dé hombre. Los jóvenes que apenas empiezan a masticar coca tienen a veces la boca muy quemada y casi no pueden comer durante los primeros días; pero desde luego, no dirán nada de eso para no perder prestigio. Sobre el efecto de la coca, los Kógi destacan en primer lugar que su consumo trae cierta lucidez mental que se debe aprovechar para las reuniones ceremoniales y toda actitud religiosa en lo general, sean conversaciones, ritos personales o ritos colectivos. Evidentemente la coca causa un estado eufórico que dura largo rato y que se prolonga por el consumo gradual de más y más cantidades. El individuo se vuelve hablador animado, dice que siente una sensación agradable de rasquiña sobre todo el cuerpo y que su memoria se refresca considerablemente, lo que le permite hablar, cantar y recitar durante horas seguidas. En segundo lugar los Kógi dicen que apacigua el hambre. Según ellos, sin embargo, eso no es el objeto del consumo de la coca sino sólo una consecuencia agradable, ya que durante las ceremonias o conversaciones ceremoniales el consumo de alimentos se prohibe y los asistentes deben ayunar. En muy raros casos se admitió francamente que la coca se masticaba con el solo fin de suprimir el hambre, ya que la alimentación era muy deficiente, pero generalmente un Kógi declara enfáticamente que la comida es plenamente satisfactoria y que la coca sólo se consume para poder mejor "hablar de los Antiguos". En lo general todos los hombres admiten que la coca tiene un efecto latente sobre la actividad sexual del individuo. Se dice que durante los primeros años de su consumo, es decir, en los años seguidos a la pubertad del joven su instinto sexual se estimula fuertemente pero que más tarde es directamente contraproducente y causa impotencia. La racionalización de este efecto es también típica, ya que toda sexualidad se considera como "mala" y peligrosa en la cultura Kógi; su supresión se considera como una de las grandes ventajas de la coca y como indispensable para las diarias ocasiones de meditación o ritos personales. Hombres jóvenes a veces no comparten este punto de vista y procuran tomar poca coca. En ocasiones toman la resolución de no usarla más o sólo a ratos cuando su uso sea directamente obligatorio. Sin embargo, expuestos a la crítica de los demás hombres sobre todo del sacerdote, estas resoluciones no son muy duraderas y la lucha por el prestigio y status vence a todas las demás consideraciones. Sea dicho que las mu- 
jeres no aprueban que los hombres usen la coca y sobre todo mujeres jóvenes sin niños provocan a veces peleas en chanza con sus maridos para que éstos dejen de usarla. Evidentemente las mujeres quienes comen mejor que los hombres y quienes no toman parte en sus actividades religiosas, son sexualmente mâs activas que éstos y saben muy bien que en el calabacito tienen un poderoso rival. Otro efecto que se atribuye a la coca es insomnio. También aquí los Kógi ven una ventaja porque las conversaciones ceremoniales se deben efectuar de noche, e individuos que pueden hablar y cantar por una o varias noches sin dormir, merecen alto prestigio. El ideal Kógi sería no comer nada fuera de coca, abstenerse totalmente de la sexualidad, no dormir nunca y hablar toda su vida de los "Antiguos", es decir, cantar, bailar y recitar. La coca es, en este caso, la planta maravillosa que ayuda al hombre a acercarse a este fin (2).

Veremos ahora qué nos dice este autor sobre las ceremonias de iniciación de los jóvenes y qué significan cada una de las partes de estas en la cultura Kógi: "El calabacito de la cal se entrega al joven durante la ceremonia de la iniciación y se le indica que este pequeño recipiente representa una mujer. El joven se "casa" con esta "mujer" durante esta ceremonia y perfora el calabacito en imitación de la desfloración ritual. El palillo, en cambio, representa el órgano masculino. La introducción del palillo al recipiente y los movimientos frotantes alrededor de su abertura lo interpretan como coito y culturalmente se da a entender que toda verdadera actividad sexual se debería reprimir y expresarse sólo en el uso de la coca. Todas las necesidades de la vida, toda la inmensa frustración se concentra así en ese pequeño instrumento que para el Kógi significa "comida", "mujer" y "memoria". Nos es raro así que el hombre Kógi sea inseparable de su calabacito. Continuamente maneja los dos instrumentos en sus manos, frotando el palillo sobre el calabacito o introduciéndolo y sacudiendo con él el pequeño recipiente o poniéndolo súbitamente de punta como para perforarlo de nuevo" (3). Como podemos colegir por la lectura de los textos anteriores, el uso de la coca está destinado entre los Kógi, exclusivamente a los hombres quienes la usan diariamente en sus prácticas religiosas. En esto tienen una gran analogía con los Chibcha de Cun-

(2) Reichel-Dolmatoff. Op. cit., 1949-1950 c, pp. 77-78.

(3) Reichel-Dolmatoff. Op. cit,, 1949-1950 d, pp. 78-79. 
dinamarca y Boyacá, entre los cuales el empleo de esta planta era en principio un hábito masculino o mejor un rito ceremonial destinado a este sexo quien ejercía el poder religioso. También vemos la racionalización del hábito a la cual ha llegado el grupo, en tal forma perfeccionada, que todas sus necesidades alimenticias y toda su actividad sexual está representada por ese símbolo. Esta es una prueba del alto grado de estructuración a que ha llegado la religión entre los Kógi.

Respecto al poder anafrodisíaco de la coca, debemos hacer una distinción entre el uso de la cocaína pura cristalizada y la masticación de las hojas de coca, pero aun admitiendo que la masticación tiene este poder probablemente por la anestesia lenta de las mucosas y por su empleo diario desde la primera juventud, no podemos negar que existe un factor psicológico bastante fuerte, que influye notablemente en el individuo y hace por lo tanto disminuír sus poderes sexuales. Esto es bien explicable puesto que el Kógi ha racionalizado en el uso de la coca todas sus aspiraciones, comida, mujer y memoria, dice que su ideal sería pasarse las noches sin dormir, hablando, bailando, recitando y naturalmente absteniéndose de todo contacto sexual. Este pensamiento ha venido predominando en el grupo por varios siglos, creando un ambiente de castración de origen psicológico. Sin desconocer la acción de la cocaína sobre las glándulas genitales del hombre y teniendo en cuenta la cantidad de coca que mascan estos indígenas, no es improbable que se logre una lenta castración o por mejor decir una impotencia sexual muy temprana, pero no hay que despreciar el factor psicológico, sobre todo cuando es colectivo y además no hay que olvidar que éste es un grupo mal alimentado, con todas las consecuencias que se desprenden de este hecho para la procreación.

En consecuencia, es evidente el arraigo de este hábito en el grupo Kógi y arrancarlo de su cultura no sería labor de poco tiempo, sino de muchos años y seguramente traería consigo una gran conmoción en las instituciones religiosas que son el centro de toda la cultura. Entre los Ika, otro grupo vecino de los Kógi y perteneciente a la misma cultura, han sido vanas las influencias de las Misiones y el poder civil, pues el uso de la coca sigue en todo su auge y así nos lo dice el Padre José de Vinalesa, quien lleva varios años conviviendo con los Ika en el pueblo de San Sebastián de Rábago, donde la Comunidad Capuchina tiene una misión, en su reciente obra sobre el grupo Ika o Arhuaco como 
él lo llama y del cual habla así: "Cualquier hombre, que pudiéramos calificar como el más empedernido fumador de tabaco, no podría, ni aún remotamente, compararse en su vicio, con ningu. no de los indios arhuacos, los cuales, no parece que hubieran nacido para otra cosa, sino para estarse toda su vida masticando hojas de coca. Indefectiblemente, todos los indios arhuacos llevan consigo, dentro de su mochila de lana, una buena porción de hojas tostadas de "Háyu" (coca). La cantidad de hojas que se pueden coger con sólo tres dedos, es la porción de una mascada.

El saludo oficial o ritual de los arhuacos, consiste en darse mutuamente un puñado de hojas de coca, cuando se encuentran unos con otros.

La cal es un ingrediente indispensable para comer el "háyu", porque facilita notablemente el desprendimiento o la extracción de la cocaína que tienen sus hojas. Los indios arhuacos, obtienen la cal por incineración de conchas marinas a las que llaman "yotínwe". Dichas conchas, después de calcinadas y reducidas a polvo, las guardan dentro del "yubúru" (el poporo); instrumento o artefacto que llevan casi siempre en las manos: el poporo es el ealabacito producido por una planta trepadora llamada "crescencia cucurbitina".

El complemento del "popóro" es un pequeño puntero o palillo llamado sókane.

Después de introducida en la boca, la cantidad requerida de hojas de "háyu", mojan con un poco de saliva la punta del palillo y lo introducen por el orificio del calabacito. La porción de cal que sale adherida al puntero, la mezclan con el "báyu" que tienen en su boca. Poco más o menos cada media hora, van añadiendo nuevas hojas y nuevas porciones de cal, al bólido que se les va formando dentro de la boca (4). "Como podemos ver, la forma de uso de la coca entre los Ika es la misma de los Kógi y también es usada exclusivamente por los hombres, como se desprende de la siguiente afirmación de Vinalesa: "Las mujeres arhuacas no toman coca ni "ambira" (tabaco). Su uso está reservado exclusivamente a los indios adultos". Y en seguida nos habla sobre la ceremonia de iniciación de los jóvenes Ika, que naturalmente es idéntica en su forma y contenido a la de los Kógi, si bien el autor explica a su gusto el significado de ella y escribe

(4) Vinalesa. Indios Arhuacos. En Revista del Instituto Etnológico. Vol. V. Entrega 1"a Bogotá, 1952, pp.40-41. 
lo siguiente: "La entrega del "yobúru", es una de las ceremonias más trascendentales en la vida de los indios. Implica ella como una declaración de mayoría de edad, y el reconocimiento de los derechos de un nuevo miembro, que entra a formar parte de la comunidad indígena. Dicha entrega la hace precisamente el Máma o Jefe encargado de iniciar a los indios jóvenes en los conocimientos indispensables para la vida conyugal".

Transcurridos los días de preparación, en una muy secreta y ritual intimidad con el Máma, recibe el indio, de manos de éste, el famoso "yobúru", debidamente preparado, para que sirva de compañero inseparable en la vida, y de eficaz amuleto que lo mantenga en inseperable armonía marital y le espante a la vez, todos los males y peligros que puedan sobrevenirle.

Es costumbre general entre los arhuacos, frotar incesantemente el palillo de su "popóro", sobre la parte superior del mismo, y debido a ello, con el poquito de cal y saliva que lleva dicho palillo, se va poco a poco formando una bola en forma de cabeza, de color amarillo verdoso. Cuando por cualquier causa, se agrieta ésta, o se rompe, tiénenlo aquellos como un aviso o señal infalible de muerte o inminente desgracia" (5). Es fácil observar que el autor no toma en cuenta el simbolismo que tiene la ceremonia e interpreta a su acomodo el ceremonial, pero en líneas generales vemos que éste es muy semejante al ceremonial Kógi para la iniciación de los jóvenes.

A estas observaciones debemos añadir que, como lo habíamos dicho anteriormente, una de las causas que hace particularmente perjudicial el uso de la coca entre estos grupos es la de agregarle zumo de tabaco concentrado, como nos lo dicen Vinalesa para los Ika y Reichel para los Kógi en las siguientes anotaciones: "Ambíra, es el tabaco que usan los indios arhuacos en la forma de extracto. La preparan, sometiendo a cocimiento muy lento las hojas maduras del tabaco, obteniendo con ello, una sustancia pastosa de color oscuro, la cual tiene reconcentradas en sí todas las propiedades de aquél.

Por ser la "ambíra" una sustancia tan venenosa y tan amarga, procuran los arhuacos, usarla con prudente moderación. La guardan herméticamente tapada, dentro de una pequeña calabacita, destinada especialmente para ello.

Los arhuacos toman la pequeña cantidad de "ambíra", mez-

(5) Vinalesa. Op. cít., pág. 42. 
clándola siempre, con la cal y las hojas de coca. $\mathrm{El}$ instrumento que utilizan para llevársela a la boca es el dedo meñique de la mano derecha" (6). Así escribe Vinalesa y a pesar de que dice que es usada con moderación, de sus escritos se desprende que el tabaco es usado juntamente con la coca y como ésta lo es tan frecuentemente, si hay alguna moderación debe ser en la dosis y no en la cantidad total del usado en el día.

Por su parte Reichel nos habla del uso del tabaco entre los Kógi en la forma siguiente: "Los Kógi conocen y cultivan el tabaco pero no lo fuman sino que cocinan sus hojas por horas y días hasta obtener un zumo concentrado y espero. Este zumo se mezcla con un poco de almidón de yuca y sagú y se guarda luégo en un pequeño recipiente ovular del calabazo (tami), que se tapa con otro parecido pero algo más grande. Con la uña del dedo se extrae una pequeña cantidad de esta pasta y se frota sobre los dientes y las encías cuando se mastica coca. Los Kógi dicen que las hojas de coca tienen a veces un sabor muy amargo y que la adición de jugo de tabaco hace su consumo más agradable. Los dientes ennegrecidos que tienen muchos hombres no son el resultado de la coca sino del consumo de esta pasta concentrada. Las plantas de tabaco crecen alrededor de las casas de habitación y siempre cerca de las casas ceremoniales. Ocasionalmente un Kógi fuma cigarros o cigarrillos regalados, pero esta costumbre no se aprueba culturalmente. Un sacerdote nunca fuma un cigarrillo y no tolera que otros indios fumen en su presencia o dentro de la casa ceremonial. Mujeres y niños nunca fuman" (7).

Evidentemente la coca mezclada con cal y además con tabaco tiene que aumentar su acción insensibilizante siendo por lo tanto más perjudicial, tanto más cuanto que el indio usa con demasiada frecuencia de este preparado. Pero la costumbre de usar la coca con tabaco no es exclusiva de los indios de la Sierra Nevada; parece que la usaron también los Chibcha de Cundinamarca y Boyacá, algunos grupos indígenas de Centroamérica y del Nor. este de Colombia. Actualmente subsiste este uso entre los Witoto del Amazonas y otros indios que utilizan el tabaco y la coca, mezclando estos ingredientes. Pero lo más interesante de observar es cómo en el área andina, la coca predomina sobre el tabaco, ya que por lo general los masticadores de coca no usan el taba-

(6) Vinalesa. Op. cit., pág. 41.

(7) Reichel. Op. cit., 1949-1950 e, pág. 79. 
co, probablemente por ser los efectos de la primera más completos y por esa causa haberse instituído un ceremonial basado en esta planta, que se transmitió de generación en generación. Es también curioso observar que el tabaco primitivamente se masticó y aún subsiste este uso y tenemos que pensar si lo primero que se masticó fue el tabaco o la coca, o si los dos vínieron en épocas distintas y predominó esta última al menos en el área andina por llenar más completamente la misión que se perseguía. En todo caso, ambos llegaron a Colombia por el Noroeste y es valioso hacer notar que diferentes grupos culturales difundieron estas plantas y su empleo por el país. Así para la coca tenemos al grupo Chibcha que se encuentra, como hemos visto, en toda el área andina de Colombia, y el tabaco fue probablemente difundido por grupos Arawak y más tarde por los Karib. El hecho es que el uso de la coca predomina entre las tribus andinas de Colombia y en cambio entre los Arawak y los Karib es bien notable el empleo del tabaco en diversas formas, así por ejemplo: entre los Piapoco y los Siusí se usa el tabaco en forma de cigarro, entre los Tikuna se emplea la pipa, mientras que entre los Chimila el tabaco es mascado. Entre grupos Karib el más notable es el Motilón, entre quienes se usa la pipa de tabaco.

Volviendo a las tribus de la Sierra Nevada, dejamos ya estudiado el cultivo, recolección y uso de la coca entre ellas y hemos comprendido que ésta es una costumbre muy antigua, culturalmente aceptada y de raigambre muy honda. Si se quiere desterrar ésta, hay que estudiar detenidamente las condiciones económicas del grupo a fin de darle un substituto alimenticio, contando con el factor religioso que es el centro de toda su cultura y procurando respetar ésta si se quieren conservar estas tribus, pues de otra manera perecerían culturalmente y se perdería esta ventana al pasado de las culturas colombianas.

Pasamos ahora a estudiar otro grupo Chibcha, más numeroso que el anterior y no menos importante que habita como ya hemos visto el Sur del Departamento del Tolima, parte del Huila y principalmente en el Cauca con su centro principal en la región de Tierradentro. En este estudio nos referiremos especialmente al grupo Páez de Tierradentro por ser el más numeroso y el mejor estudiado, y por la circunstancia de que el autor de este trabajo permaneció en esa región durante los primeros meses del año pasado, obteniendo nuevos datos y comprobando otros ya obtenidos por investigadores anteriores. 
Ya hablamos ampliamente sobre la situación geográfica de Tierradentro y dijimos algunas generalidades sobre la cultura de los paéces, por lo tanto nos parece inoficioso mencionarlo aquí. Dijimos también que en este grupo mascaban la coca con cal en especial los hombres, pero también algunas mujeres y niños, sobre todo en los últimos tiempos esta costumbre está muy generalizada entre el sexo femenino y los niños de ambos sexos, quizá por las difíciles condiciones alimenticias que atraviesa la región durante los largos veranos que la azotan en los meses de Julio, Agosto y Septiembre, con los cuales se terminan las cosechas y viene una época de gran escasez denominada por los paéces "hambruna"; es durante esta época cuando en la casa no quedan más que las mujeres, los niños y los viejos imposibilitados para el trabajo pues el resto de la población masculina sale a las vegas y pueblos cercanos a trabajar como jornaleros de los blancos y mestizos que tienen cultivos en esas regiones.-En la parcialidad de Mosoco varía esto, pues allí tienen cultivos de papa (doble cultivo) que cosechan en abril y mayo; siembran nuevamente y cosechan en agosto y septiembre y aún en agosto siembran para la última cosecha; además, cosechan majuas, uyucos y tienen ganado vacuno de buena clase.-S. Bernal Villa.

Dentro de la cultura Páez la coca hace las veces de suplemen. to alimenticio y hace parte de las ceremonias mágicas del médico (shaman) del grupo y aunque los paéces profesan desde hace varios años la religión católica, ésia está mezclada con creencias que hacen parte de su ancestro cultural, entre ellas la de la coca, la cual ofrecen con todos los productos de su tierra el día de la ofrenda, considerándola planta maravillosa, fuente de energía y sustento. En fin, es costumbre bien arraigada en su cultura y si no racionalizan su uso al igual de los Kógi, la consideran muy valiosa y la cultivan, cosechan y preparan con sumo cuidado, como veremos a continuación:

Siembra de la coca. La siembra la hacen únicamente los hombres, pues tradicionalmente lo han hecho; para ella no hay ceremonias especiales, solamente se hace una "minga" (reunión) de vecinos y se permanece sembrando, bebiendo chicha y comien. do en los descansos, hasta terminar la siembra del terreno, "minga" que se prolonga por varios días; para ésta se sacrifica por lo general una cabeza de ganado vacuno, de la cual comen todos los participantes. La coca es sembrada en los valles cálidos y templados, especialmente en Togoima, Avirama, San Andrés y 
la Palma entre los 1.500 y 2.000 metros de altitud. Se puede sembrar sola pero es más común sembrarla alternada con los cultivos de caña de azúcar, café y plátano, pues éstos le dan sombra que es conveniente para el buen crecimiento de la planta. Al año de sembrada ya se puede coger cosecha de hojas y a los cinco años, los árboles son lo bastante grandes como para permitir cosecha en cualquier época.

Cosecha de la hoja. No hay época especial para la cosecha de la hoja, cualquiera es buena. Esta la hacen especialmente las mujeres pero también la pueden hacer los hombres. Se recoge la hoja en jigras que llevan pendientes del hombro y para ello se esoge la más madura, es decir, aquella que tenga un color verde claro.

Preparación de la hoja. Recogida la hoja es llevada a la casa para la preparación. Allí se recibe en grandes ollas viejas de barro y se procede a tostarla a fuego lento, volteándola continuamente para que la tostación sea pareja. Cuando la hoja adquiere un color verde-oscuro con visos dorados, está lista para su consumo. Se coloca entonces en unas bolsitas de lana tejidas por las mujeres, llamadas "Kuetan-diajas" y que todo individuo de la tribu lleva colgadas del hombro.

Preparación de la cal. La región es rica en rocas calizas que producen muy buena cal. Hay sitios especiales de donde sacan la cal y a ellos van hombres o mujeres indistintamente. Llegados allí se procede a romper la roca por medio del fuego que una vez rota se transporta a la casa, donde se tiene por quemarla cuando se hace necesaria. Esto se hace en las primeras horas de la mañana y se usa para ello un tiesto en el cual se coloca al fuego y cuando está al rojo vivo se le echa agua, con lo cual la piedra se rompe en pedazos de color blanquecino opaco, ésta es la cal usada para mezclarla con la coca. Se lleva en un calabacito (kuetand-tuka) que se coloca en la misma bolsa de las hojas de coca.

Forma de usar la coca. El "mambeador" (individuo que masca coca con cal) toma una "mascada" de hojas tostadas de su "kuetan-diaja" y las introduce en la boca, donde forma con ellas una pelota que masca durante unos minutos, luégo de la "kuetandtuka" echa la punta de una navaja de cal entre los dedos pulgar e índice, exactamente en la llamada "tabaquera anatómica" y la pone en la boca mezclándola con las hojas. La cal se añade a la 
coca, hasta que ésta adquiera un sabor dulce y entonces dice el "mambeador" que "está buena" y no le añade más cal. Como la "mascada" produce una abundante secreción salivar, escupen de vez en cuando un zumo verdoso. La primera "mascada" la hacen más o menos a las seis de la mañana cuando salen al trabajo; a las nueve la segunda que les dura aproximadamente hasta las doce, en la cual descansan. A esta hora se reúnen para charlar con sus compañeros y beber guarapo (chicha de caña de azúcar) y si han llevado comida la reparten entre ellos. Después del descanso hacen la tercera "mambeada" que alcanza hasta la hora de terminar el trabajo, más o menos. Si el camino de su casa al lugar de trabajo es muy largo, entonces hacen una última "mam. beada" que botan en cuanto empiezan la última comida, más o menos entre las seis y las siete de la tarde. Pasada ésta ya no "mambean", sino que permanecen conversando y riendo hasta la hora de acostarse.

Las mujeres en cambio "mambean" en cualquier hora del día o de la noche, ya que ellas generalmente se quedan en casa dedicadas a hilar, tejer, cuidar de los niños y preparar la comida, pero más o menos consumen una cantidad de coca equivalente a la de los hombres.

Desde muy pequeños, por regla general entre los ocho y los diez años, los paéces aprenden a mascar coca. La primera impresión es de que ésta les pica y que les pela el paladar y los labios, pero se ven obligados a usarla porque los padres se enojan si no lo hacen. Cuando el niño sabe "mambear" está en capacidad de trabajar. El Páez no puede concebir el trabajo sin coca. Ella significa satisfacción alimentncia, vigor, energía, euforia. Lo contrario cansancio, fatiga, hambre.

Medidas de la coca. La coca se mide por libras. Cada libra la componen diez huevos que tienen el tamaño de un huevo de gallina aproximadamente y el número de hojas de cada huevo es indefinido. Una libra es cantidad suficiente para el consumo de un individuo durante una semana. Consume aproximadamente un huevo diario. El precio de la libra es de dos y hasta de tres pesos. Anteriormente era de cincuenta centavos pero ha subido hasta alcanzar el precio actual. Durante las fiestas es cuando el consumo de coca es mayor; cada individuo compra por lo general cinco libras si se trata de fiestas menores y doce en las mayores, con el fin de obsequiar a los asistentes. 
Comercio de la coca. La coca es en Tierradentro una especie de moneda. Comercian con ella de una parcialidad a otra y dentro de la misma, cambiando animales domésticos como gallinas, cerdos y aún ganado mayor. Aprecian mucho sus cultivos y se considera hombre rico aquel que posea varias plazas de coca. En general es usada en cualquier clase de transacciones comerciales a cambio del dinero que solamente usan en su comercio con los blancos.

Otros usos de la coca. También es utilizada por el médico en las ceremonias de curación y en las de adivinación donde la coca es usada alternativamente para alejar el mal soplando con ella sobre el enfermo o para entrar en trance adivinatorio, mascando en silencio por algún tiempo. Por último es usada además por el mismo médico para la limpieza de la familia de algún muerto. Sobre el ceremonial de estas actuaciones del médico, véase (8):

El indio Páez admite que come coca porque ello le quita el hambre en las horas de trabajo y le da fuerzas para esto y que así ha sido usada desde muchas generaciones atrás. El día de la ofrenda, ofrece junto a las cosas más preciadas, unas hojas de coca y ya hemos visto cómo la utiliza el médico en sus ceremonias. De todo esto se desprende el pensamiento de que el uso de la coca hace parte de la cultura Páez. Sin embargo, últimamente las misiones han detenido mucho el avance de ese hábito en el elemento joven, aunque de adultos y por las necesidades que implica una faena ruda la toman y esta vez no la dejan sino a la muerte. Si se pretende desterrar este hábito del grupo, es necesario, primero una educación agrícola desde la niñez y un decidido apoyo económico del gobierno, es decir, el establecimiento de granjas donde se enseñe al niño a cultivar con cierta técnica moderna y la ayuda económica por medio de semillas y elementos agrícolas modernos. Es en el niño indígena y no en el adulto hecho ya a la cultura del grupo, en quien hay que inculcar estos procedimientos. Medidas drásticas como la prohibición del cultivo y la destrucción de las plantaciones, no traerían más que desórdenes sociales y económicos. Es necesario que el indígena que cultiva sus tierras de una manera exhaustiva, aprenda a aprovechar sus reservas y a cultivar otras plantas en una forma que dé más rendimiento. Mientras tanto el indio Páez seguirá consu.

(8) Bernal Vila. Magia y Medicina entre los Paeces. En Revista Colombiana de Antropología. Vol. II, No 2, 1954, pp. 221 a 246. 
miendo la coca como único aliciente en su trabajo y como complemento de su alimentación deficiente. El caso de estos indigenas es menester no considrarlo a la ligera ya que se trata de un núcleo de población bastante numeroso y si se le quiere dar la ciudadanía colombiana es necesario darle todas las ventajas de que se supone debe gozar todo miembro de la Nación. Es necesario educarlo sin destruír su cultura y respetando su personalidad. Además hay que contemplar otros problemas biológicos. Las enfermedades infantiles que ha adquirido en contacto con el blanco son muy virulentas entre ellos y causan grandes bajas. El alcoholismo no de chicha, sino de aguardientes y rones tóxicos expendidos en los estancos oficiales, preparan al indígena para la tuberculosis, y si se suma a esto la mala alimentación agravada por el parasitismo intestinal, tenemos que enfrentarnos con problemas más graves que el de la masticación de las hojas de coca.

Estudiados estos dos principales núcleos indígenas entre quienes se mastica la coca, uso bien establecido, como que lo tiene en su haber cultural desde hace varios siglos, vamos a considerar entonces una variación en el consumo de la coca. Es entre las tribus que habitan nuestras intendencias y comisarías donde el uso de la coca varía en su forma de consumo ya que no en su fin. Alli la planta es ingerida, pero el objeto de esta ingestión es también aplacar el hambre y la fatiga. Veremos entre qué tribus principalmente existe este uso.

Anteriormente hemos visto la localización geográfica de las diferentes tribus de las familias lingüísticas Arawak, Tukano, Tupiguaraní y Witoto, entre quienes se encuentra la costumbre de ingerir la coca. Ahora únicamente vamos a tratar de la forma de cultivo, de la recolección y el uso entre dichas tribus. Veremos, en primer lugar, estos particulares entre las tribus Arawak y Tukano del Vaupés: Entre éstos la coca se siembra en hileras dejando espacio entre una y otra mata. Las matas se limpian frecuentemente para defenderlas de las hormigas y otras plagas de la selva. El cultivo está a cargo de los hombres. Solamente la recolección es verificada por mujeres, pero también intervienen los hombres. La cosecha se realiza por lo general en las horas de la mañana y se recogen las hojas en un gran cesto, que llevan pendientes de la cabeza o del hombro izquirdo, prefiriendo las hojas que estén más maduras y apretándolas en el cesto hasta llenarlo completamente. Hecho esto las conducen a la "Maloka". 


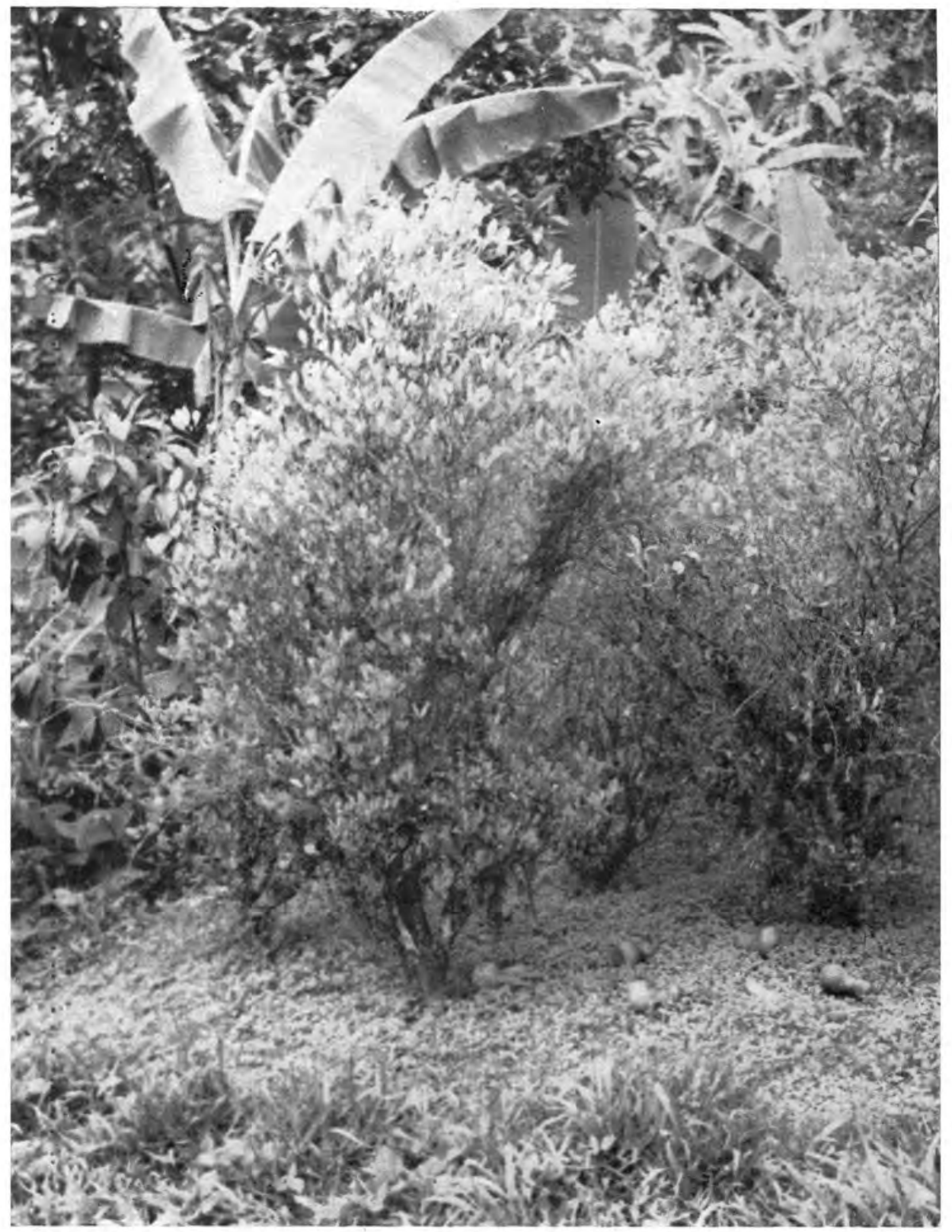

Sierra Nevada de Santa Marta. Sembrado de coca de los Indios Kógi. En el suelo, bajo las matas, han depositado calabacitos "poperos", en calidad de ofrenda.-Cortesía G. Reichel-Dolmatoff. 


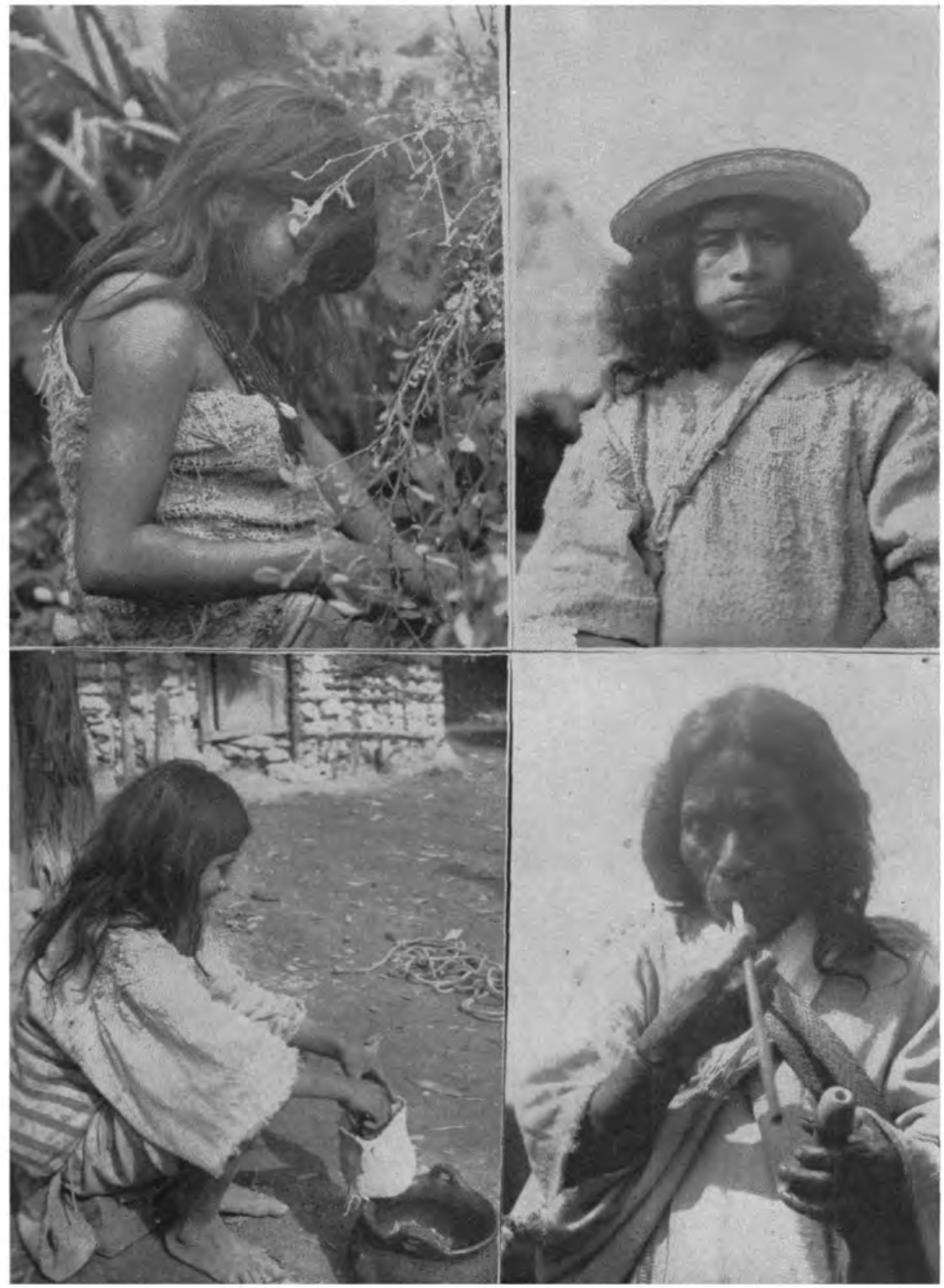

Sierra Nevada de Santa Marta. Superior izquierda. India Kógi cosechando hojas de coca. Inferior izquierda. Indio Kógi llenando su mochila con hojas de coca que acaba de tostar en una vasija ceremonial. Inferior derecha. Indio Kógi con el calabacito para la cal y el palillo para extraerla. Superior derecha. Indio Kógi masticando coca con cal.-Cortesía G. Reichel-Dolmatoff. 


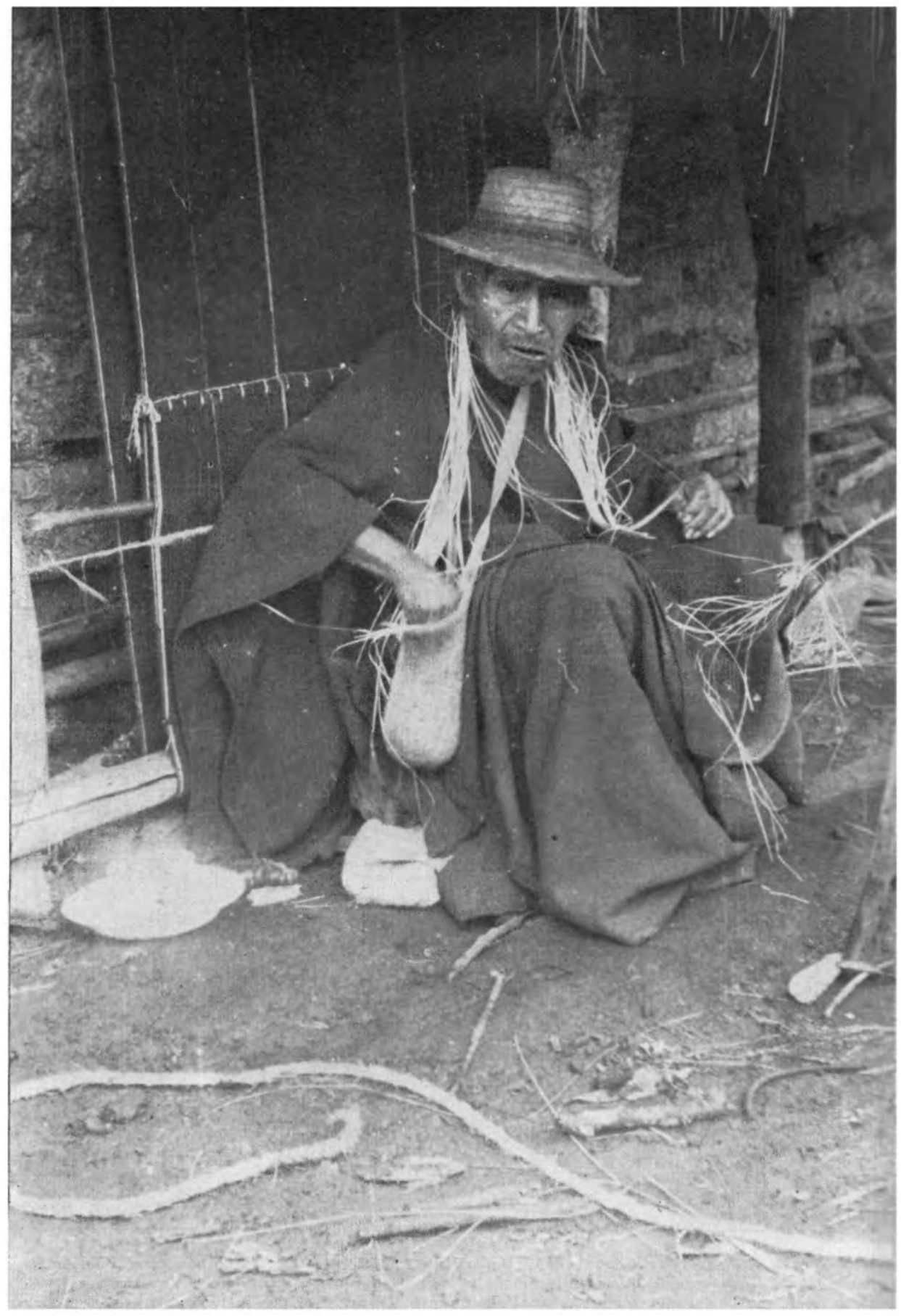

Viejo indio Páez masticando coca.-Fototeca. Instituto Colombiano de Antropología. 


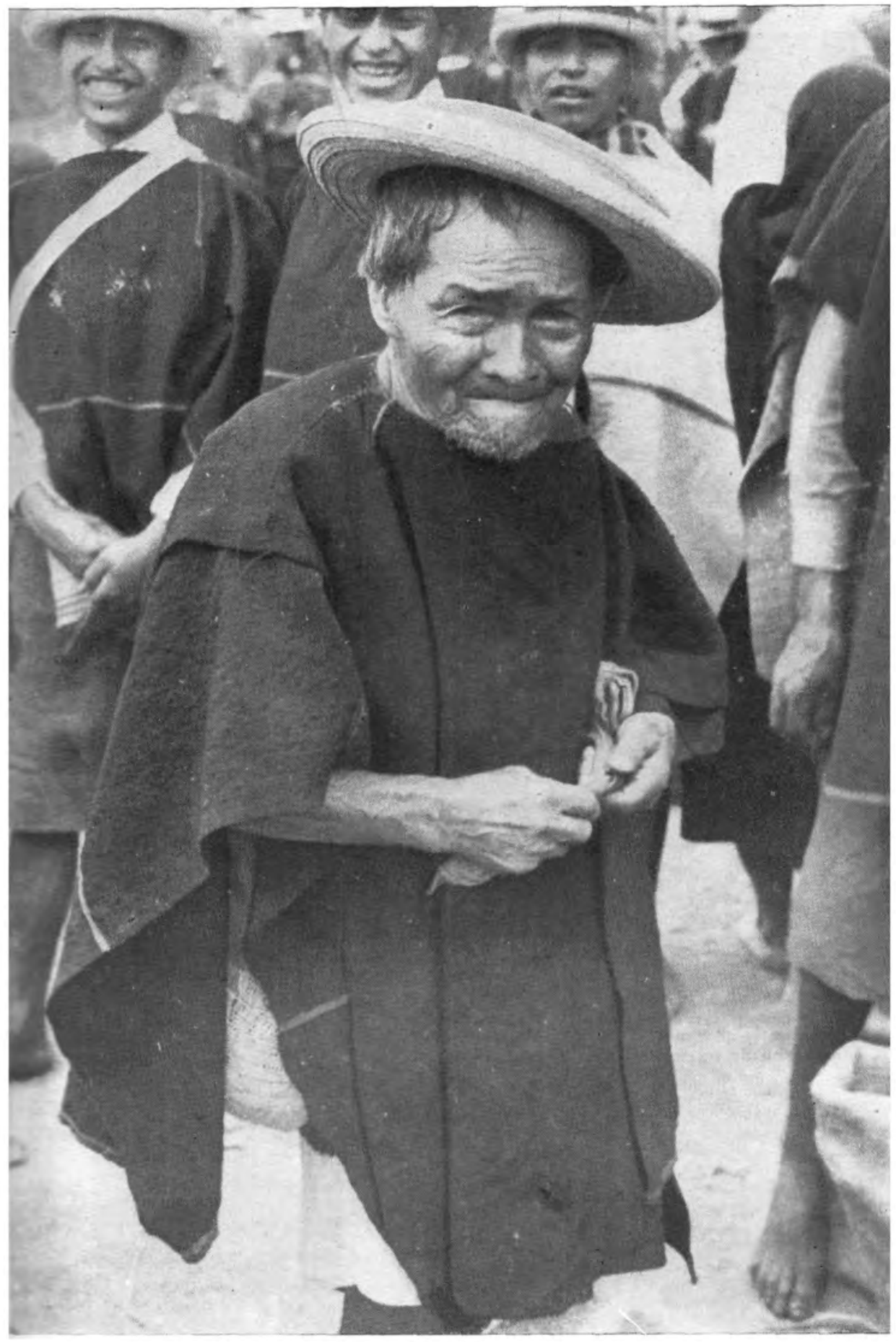

Indio Guambiano, viejo "mambeador"-Fototeca. Instituto Colombiano de Antropologia. 


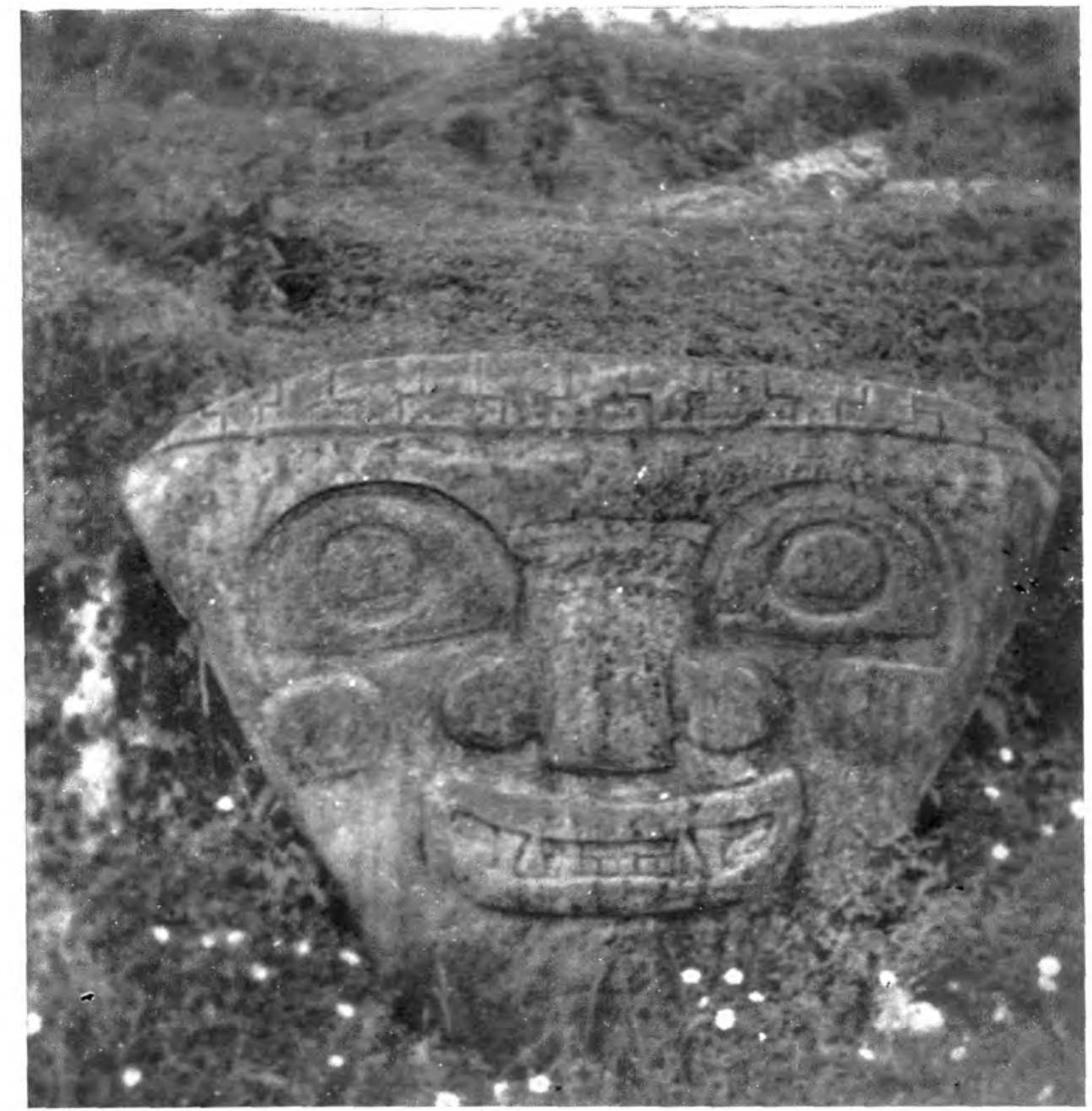

Gran cara triangular del montículo N.W. de la meseta B, descrita por Preuss y considerada por Pérez de Barradas como representación del acto de masticar la coca. Como puede observarse a simple vista, los abultamientos que presenta esta figura, se encuentran en los pómulos y no en los carrillos, como se encontrarian de representar bolas de coca. 


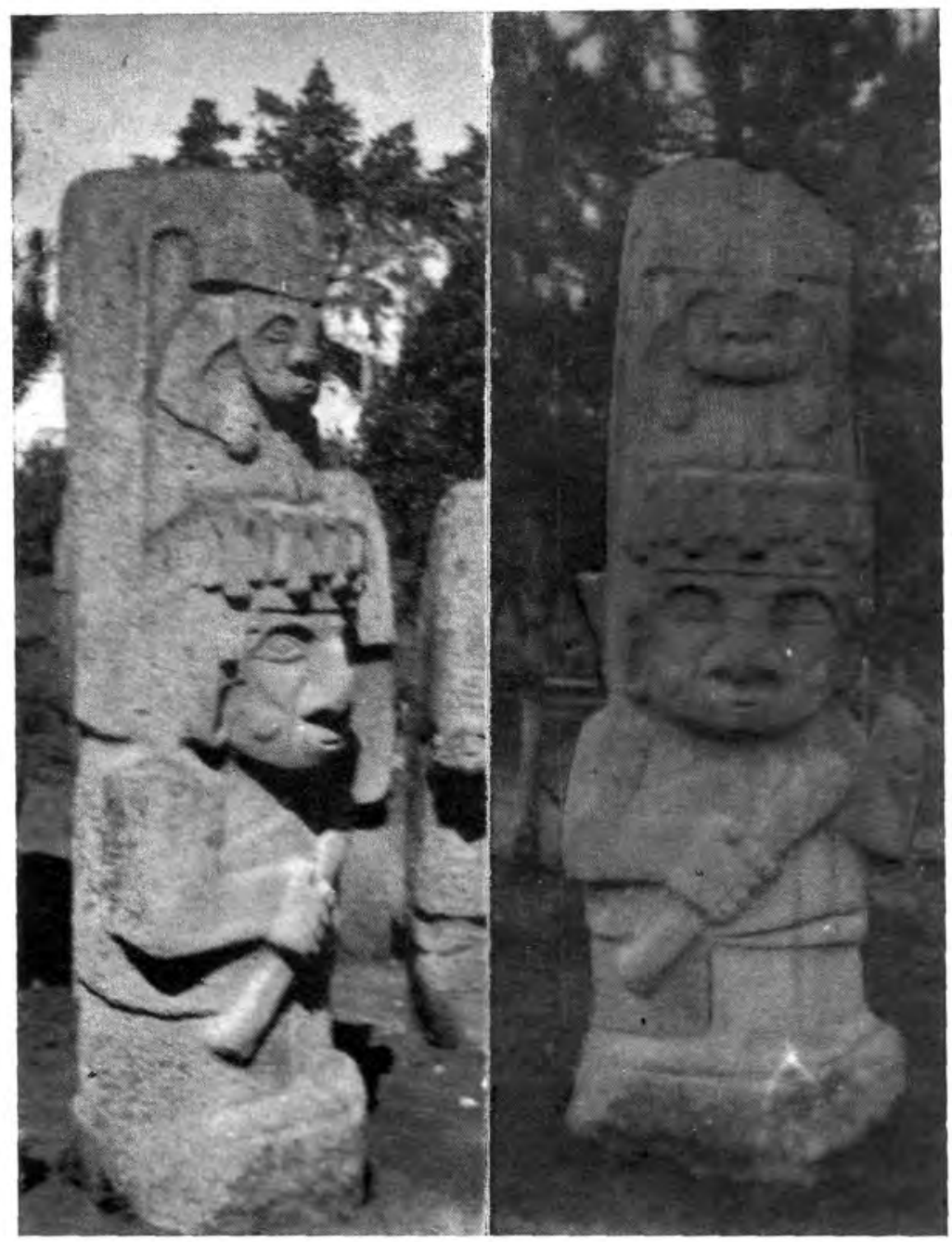

Cariátide del templo superior del montículo $\mathrm{N}$ W de la Mesita B. Considerada por Preuss y Pérez de Barradas como representación del acto de masticar coca. En la lámina izquierda se puede apreciar el abultamiento en uno de los carrillos y en la boca. La figura superior parece presentar similares abultamientos. La lámina derecha muestra dichas prominencias en los dos carrillos. 
donde se somete a un proceso de tostación en un tiesto plano (putú o patú). Se arrojan puñados de hojas en el tiesto puesto sobre el fuego y con la mano se van removiendo para secarlas; cuando están más o menos de un color verde claro se las seca al aire. Luégo se pilan en un pilón de madera contundiéndolas con un palo. Previamente tienen quemadas hojas de yarumo (cecropia), que se mezclan con la coca en una totuma (cuyabra) y esta mezcla se pasa por un tamiz de corteza de árbol. El polvo obtenido por medio de este tamiz, se guarda en calabacitos esféricos muy bien pulidos, que se llevan por medio de una faja tejida sobre el hombro izquierdo, o también en una mochila de cortaza roja. Este polvo se aspira por medio de un hueso tubular de garza que va atado a la boca del calabacito o de la bolsa, o bien se lleva a la boca por medio de una cuchara de hueso, tallada en el fémur de un jaguar o por medio de una hoja de plátano.

Es consumida generalmente en viajes y fiestas de la tribu por su poder estimulante, inhibidor de la fatiga y el hambre. También la usa el brujo en sus ceremonias. El objeto de este consumo es el de suplir la alimentación y el de obtener un mayor rendimiento en las largas jornadas por la selva, así como lograr un estímulo en las prolongadas fiestas de la tribu. Naturalmente su uso por el brujo le da a esta un carácter mágico, ya que este pronuncia una especie de conjuro sobre el calabacito antes de usarlo.

Estudiaremos ahora el uso de la coca entre las tribus de la familia lingüística Witoto. A este respecto nos dice Murdock: "El arbusto de la coca exige cultivo esmerado. Sus hojas que contienen cocaína, se tuestan, se pulverizan en un mortero y se mezclan con arcilla calcinada, harina de manioca y cal obtenida que. mando hojas de palma. Con un taco de esta mezcla en la boca, un hombre puede pasarse varios días sin comer, beber ni dormir nada y realizar maravillosas hazañas de resistencia" (9).

Por su parte los misioneros que han recorrido las regiones habitadas por estos indios, nos dan valiosos datos sobre el empleo de la coca entre ellos. A continuación transcribimos algunos. Mons. Gaspar M. Monconill, nos dice: "Cogen las hojas de la coca con ramita y todo, de una vara de un metro o de una braza de largo, son las que hacen "guanguitos" amarrados con bejuco o la llenan en canastos para llevarla a la casa. Recogen hojas secas de yarumo del que se produce en rastrojo de tierra firme

(9) Murdock. Op. cit., p. 379. 
del interior de la montaña y hacen "guangos" o los ponen en canastos como las hojas de coca. A este yarumo lo llaman en su idioma "Curagno" (Queragni - el sonido de la $e$ es muy apagado-). A las hojas secas de este yarumo las llaman en huitoto "duiga-biague".

"Al llegar a la casa deshojan las ramas de coca, van poniendo las hojas en un cedazo de cernir "casabe" (tejido de una palma llamada "yaruma"), los palos los van dejando a un lado formando un guango grande. Echan las hojas dentro de una grande olla de barro que sólo la destinan a esta operación. Antes de echar las hojas a la olla la hacen calentar a fuego lento; al estar tibia la olla le echan la hoja y la van meneando con la mano y aumentando el fuego mientras ellos pueden aguantar a menear las hojas con la mano sigue esta operación hasta que la hoja se deshace al tacto que es el punto bueno del tostado. Cuando la hoja de coca está dando punto el tostador avisa a otro para que prenda las hojas secas de yarumo. Cuando las hojas de yarumo están prendiéndose otro pone las hojas de coca a un pilón largo y estrecho (una cuarta de ancho por una vara de largo) y las van pilando hasta que quedan hechas polvo. Cuando las hojas de yarumo están reducidas a ceniza el que las prendió recoge esta ceniza en un mate (a esta ceniza llaman ellos "imuye"). Ponen la coca pilada o hecha polvo en otro "mate"; revuelven la coca con ceniza hasta que haya más o menos partes iguales, le encierran en un pañuelo y en él lo ciernen; el polvo que cae es la coca que ellos toman.

"Hecho lo indicado anteriormente se reúne toda la gente presente por invitación del capitán, se sientan al suelo formando ruedo en medio del cual hay un "matecito" de tabaco con una preparación especial que se explica aparte. El dueño de la coca coge el mate o batea donde está y va distribuyendo a todos los presentes, quienes la reciben en la mano, boca, cuchara; después ponen un poco en una talega para ir tomando mientras los viejos y los más inteligentes van contando sus historias, tradiciones, dando avisos, etc. Así pasan a veces toda la noche" (10).

De los párrafos anteriores se desprende que el uso de la coca es más o menos el mismo entre los Witoto y las tribus Tukano y Arawk del Vaupés. Para los Witoto y otras tribus observamos sin

(10) Monconill. Manera como preparan Ia coca los indios Uitoto en general. En Revista Amazonia. Tomo III. Nros. 9 y 10, 1945, pp. 41-42. 
embargo que en ciertas ocasiones le agregan tabaco concentrado en forma parecida pero no idéntica a los indios de la Sierra Nevada de Santa Marta. Este tabaco lo preparan en la forma siguiente: "Se coge la hoja verde de tabaco y se cocina con agua hasta que se ablande; una vez blanda, se exprime y se bota la hoja; el jugo exprimido se cocina hasta que se vuelve miel. Cuan. do el cocimiento empieza a espesarse se le echa un poco de agua de yuca o de agua de la que sale cuando se exprime la yuca para hacer casabe; se sigue cocinando hasta que esta mezcla se convierte en una especie de miel espesa; se deja enfriar y se vuelve duro: este es el tabaco que mascan los indios."

"Para hacer la fiesta se reúnen como hemos dicho en la preparación solemne de la coca y ponen en medio del grupo un matecito con un poco de agua fría, dentro de esta agua meten un poco de ceniza de fogón, con los dedos van deshaciendo la bola del tabaco. Van hablando y en señal de que asienten a lo que dicen los que hablan van metiendo todos el dedo en el mate y lo lamen, otros meten los dedos, otros un palito, etc. Van mascando la coca como hemos dicho, lamiendo de vez en cuando los dedos untados de tabaco en señal de aplauso cuando alguno les parece que habla muy bien gritan todos un fuerte iiv que significa ¡viva! Así pasan a veces toda la noche" (11).

En todos los sitios donde viven los Witoto se consume la coca y la forma de prepararla es idéntica. Así tenemos otro ejemplo de ello en los datos recogidos por el Padre Mateo de Pupiales entre la tribu Witoto de Tarapacá, de los cuales escribe lo siguiente: "La coca es un arbusto que alcanza un desarrollo hasta de tres metros en tres años, sus hojas son como las del limón, pero más redondas, más delgadas y más amarillas. Antes de un año, el arbolito ya beneficia al dueño, pues, aunque da unas semillitas parecidas al café, son las hojas las que los indios utilizan del modo siguiente:

Cogen todas las hojitas de los árboles hasta juntar cuatro o cinco arrobas; las llevan a la casa y las tuestan a fuego lento; cuando están bien secas las pulverizan y lo que eran cincuenta kilos se reducen a cinco o diez; entonces las mezclan con las hojas de un árbol llamado yarumo, con cenizas de algunas palmas y a veces con polvo de tabaco.

(11) Monconill. Preparación del tabaco entre los indios Uitoto. En Revista Amazonia. T. II. Nros. 9 y 10, pp. $42-43$. 
Y está hecha la felicidad de esos pobres indios; la comen de día y de noche y en sus reuniones; la usan para sus ceremonias y regalos ordinarios. Cuando llega una visita lo primero que le ofrecen es un puñado de ese polvo que se lo echan a la boca inmediatamente colocándola a lado y lado; poco a poco, a medida que se les va viniendo la saliva a la boca se lo van engullendo.

Que les hace mal es cosa evidente; pero querer convencerlos de que no la usen es como querer convencer a un borracho de que no tome; pues los indios aseguran que comiendo coca no sienten ni hambre, ni sueño, ni cansancio; y así es: con su coca pasan días sin comer ni dormir; pero apenas aguantan y a la larga van para atrás.

Las mujeres no comen coca; por eso gozan de buen apetito y sueño; por eso se nota en ellas superioridad física y mental" (12).

De esta nota deducimos en primer lugar que la coca es ingerida, diferenciando así su uso del de las tribus andinas que únicamente la mascan, y segundo que es usada exclusivamente por la población masculina, lo que comprueba que hay ciertas prohibiciones de carácter mágico o religioso que prohiben su uso a las mujeres.

Finalmente vamos a transcribir algunas notas que muestran el empleo que se da a la planta entre los Bora (Tukano), que viven entre los ríos Ira y Guama, en el borde izquierdo del Ca. quetá, como también en casi todas las vertientes del río Cahuinarí hasta la cabecera del río Putumayo en su banda izquierda, más arriba del Yaguas (13), y entre los Miraña (Tupiguaraní) y Rosiggaro (Arawak), los primeros en el río Cahuinarí y sus afluentes y los segundos en la Chorrera (en un afluente del $\mathrm{Pu}$. tumayo (14).

En primer lugar el Capuchino Bartolomé de Igualada, nos describe su entrada a una tribu de indios Miraña en el río Cahuinarí: "Como mi llegada constituía un verdadero acontecimiento que debían comentar, se prepararon en seguida para ello. Trajeron gran cantidad de hojas secas del árbol frutal llamado huva

(12) Pupiales. La coca entre la tribu Uitoto de Tarapacá y Piuña Negro. En Revista Amazonia Americanista. T. II. Nros. 9-10. Sibundoy, 1945.

(13) Pinell. Excursión Apostólica por los ríos Putumayo, San Miguel de Sucumbíos, Cuyabeno, Caquetá y Caguán. Bogotá, Imp. Nal., 1929.

(14) Igualada. Descubrimientos de nuevas tribus indígenas. Tres emocionantes exploraciones misionales en el río Cahuinarí. En Boletín de Estudios Históricos. Vol. VII. No 83, pág. 301. Pasto, 1938. 
y las queman en medio de la coca que ya tenían preparado (hojas de coca tostadas, pulverizadas y cernidas). Acabado esto, comenzó la asamblea: puestos en circunferencia en torno las cenizas, principian a tomar de ésta hasta dejar abotagados sus carrillos. Cada uno traía pendiente del cuello un pequeño coco que contenía zumo de tabaco sumamente fuerte. De cuando en cuando introducía el palillo en el zumo y lo llevaban a la lengua. Al principio hablaban poco como esperando la inspiración de la coca y el tabaco, pero poco a poco se fueron animando gradualmente hasta que por la madrugada (la toma de coca dura toda la noche y con la misma posición) aquello era una verdadera algarada de mujidos y peroratas" (15). Y más adelante habla de sus compañeros de expedición en la forma siguiente: "los pocos com. pañeros que debía llevar puede reducirse solamente a los siguientes: Pastos Caimeraquito (huitoto), José Mosco (rosíggaro), más otro rosíggaro de la casa donde nos encontramos llamado Maribba; los primeros de la Pedrera y el último de la Chorrera" (16). Luego describe su encuentro con los Boras de la quebrada de Itchajú en el siguiente aparte: "Después los hombres de ambos bandos se reúnen en torno de un hueco donde estaban las cenizas según costumbre que ya conocemos; y temblorosos y emocionados fueron tomando dicho polvo por montones, juntamente con el zumo de tabaco" (17). Posteriormente y al describir su segunda excursión apostólica en la cuenca del río Cahuinarí, nos señala la posición de una tribu Miraña, cuando dice: "Dos horas y media más arriba de la boca (del Cahuinarí) está la pequeña tribu de los Miraña del capitán Chineiva, cuyo número de habitantes asciende a unos 80 " (18). Y en seguida habla del ceremonial de brujería que practica su compañero Mosco, en la cual hace parte principalísima la coca. "El brujo Mosco aprovecha la demora, se interna en el monte. Ya al caer la tarde regresa cargado de ciertas plantas con las que de noche preparará aquella salsa vegetal que después será revuelta con polvo de coca; así esta resulta según ellos más eficaz para adivinar las cosas y librarse de muchos males.

Ya bien oscurecida la noche, el brujo se desnuda y se coloca el grueso collar de colmillos de tigre. Principio quemando las refe.

(15) Igualada. Op. cit., p. 300.

(16) Ibid, p. 301.

(17) Ibid, p. 306.

(18) Ibid, p. 313. 
ridas plantas que, transcurrida una media hora, quedan convertidas en un montón de cenizas negras. Mete luego estas cenizas en una especie de canastillo preparado de antemano esta misma tarde, bien forrada con hojas de platanillo. Lentamente impregna de agua las cenizas, hasta que al fin se pone a cocinarlas. Todas estas tareas van acompañadas de verbosidad continua del brujo, correspondida a coro, por los característicos rugidos de aprobación de los compañeros que se hallan formando eircunfe. rencia en torno de las cenizas en ebullición" (19). Continúa describiendo la lucha del brujo con un terrible huracán: "El brujo se halla en su ambiente y pone en acción toda su magia: desnudo como una esfinge en medio de la playa, lanza contra el huracán manotadas de polvo de coca. Amenaza con su diestra las nubes y las mira con aire de desafío" (20). En estos apartes vemos la gran importancia que tiene la coca entre estos indígenas, pues no solo tiene un gran papel social, sino que es usada en todas las. ocasiones en que el hombre lucha con las enfermedades o la na. turaleza. Destacaré el aspecto de la coca como función social entre las tribus indígenas coolmbianas en próximo artículo sobre el particular. Por el momento fínalizo hoy este estudio de los grupos indigenas que usaron la coca y los que la usan actualmente. Esto no quiere decir que el estudio haya sido exhaustivo, pues seguramente un examen más a fondo de las fuentes etnohistóricas nos permitirá llenar muchos de los vacíos aún existentes. Por otra parte, esperamos que futuras investigaciones de campo, nos suministren datos más recientes sobre las tribus indígenas que conservan este uso y en futuras publicaciones prometemos aclarar muchos interrogantes.

Néstor Uscátegui Mendoza

(19) Ibid, p. 315.

(20) Igualada. Op. cit., p. 315. 


\section{BIBLIOGRAFIA}

Acosta (Joseph de) : Historia natural y moral de las Indias. Madrid. 1894.

Barcelona (Javier de): Huma-El Tesmóforo Huitoto, Revista Amazonia Colombiana Americanista. T. II. No 4. Sibundoy. 1941-1944.

Bejarano (Jorge): Nuevos conceptos sobre el cocaísmo en Colombia. América Indígena. Vol. XIII. No 1. Méjico. D. F. 1953.

Bonilla IragorRI (Gerardo): El problema del cultivo y masticación de hojas de coca en Colombia. Popayán. 1947.

Bernal Villa (Segundo): Magia y Medicina entre los Paeces. Revista Colombiana de Antropología. Vol. II. NQ 2. Bogotá. 1954.

Cieza de León (Pedro) : Historia del Nuevo Reino de Granada. Edición de A. Paz y Melia, Madrid. 1886.

Castellvi (Marcelino de): Materiales etnobotánicos sobre el tabaco y la coca. Revista Amazonia Colombiana Americanista. T. II. Nos. 4-5-6. Sibundoy. 1941-1944.

Castellvi (Marcelino de): La Macrofamilia lingüistica Witoto. Revista Amazonia Colombiana Americanista. T. V. Nos, 17-19. Sibundoy. 1953.

Cartagena (Alberto de): Palabras indigenas relacionadas con "los apuntes sobre el baile" en algunas tribus de la región Sur-Oriental de Colombia. Revista Amazonia Colombiana Americanista. T. V. Nos. 17-19. Sibundoy. 1953.

Chávez (Milcíades): Mitología Kágaba. Boletín de Arqueología. № 5. Bogotá. 1947.

Duque Gómez (Luis) : Notas sobre el cocaismo en Colombia. Boletín de Arqueología. Vol. II. Nos. 5-6. Bogotá. 1945.

Frazer (Sir James George): La Rama Dorada. Segunda Edición española. Méjico. Fondo de Cultura Económica. 1951.

Fernández de Piedrahita (Lucas): Historia General de las Conquistas del Nuevo Reino de Granada. Bogotá. 1881.

Friede (Juan) : El Indio en la lucha por la tierra. Bogotá. 1944.

Friede (Juan): Los Andakí. Méjico. Fondo de Cultura Económica. 1953.

Gutiérrez Noriega (Carlos): El hábito de la coca en el Perú. América Indígena. Vol. IX. No 2. Méjico. D. F. 1949.

Gutiérrez Noriega (Carlos) : El hábito de la coca en Sudamérica. América Indígena. Vol. XII. No 2. Méjico. Abril. 1952.

Godden Mortimer (W.) :Perú History of Coca. The Divine Plant of the Incas. New York. 1901.

Garcés (V. Gabriel) : El Indio Ecuatoriano y la Coca. América Indigena. Vol. V. No 4. México, D.F. 1945.

Haury y Cubillos (Emil y Julio César): Investigaciones Arqueológicas en la Sabana de Bogotá. Universidad de Arizona. Boletín No 22. Tucson. 1953.

Hernández de AlBa (Gregorio): The Highland Tribes of Southern Co. lombia. Hanbook of South American Indianss. Vol. II. Washington. 1946. 
Hernández de Alba (Gregorio): Sub-Andean Tribes of the Cauca Valley. Hanbook of South American Indianss. Vol. IV. Washington. 1948.

IgualadA (Bartolomé de): Descubrimiento de nuevas tribus indigenas.

Tres emocionantes exploraciones misionales por el río Cahuinarí.

Boletín de Estudios Históricos. Vol. VII. N. 83. Pasto, 1938.

JimÉnez (Edith) : Los Guane. Boletín de Arqueología. No 3. Bogotá, 1945. Jultán (Don Antonio): La Perla de América Provincia de Santa Marta. Madrid, 1787.

Krieckeberg (Walter) : Etnologia de América. México, Fondo de Cultura Económica. 1946.

Koch - Grumberc (Theodor) : Les Indiens Ouitotos. Journal de la Societé des Americanistes. T. III. París, 1906.

Koch - Grumberg (Theodor): Zwei Jahre bei den Indianer Nordwest Brasiliens. Stuttgar, 1923.

León (Luis A.): Historia y extinción del Cocaísmo en el Ecuador. Sus resultados. América Indígena. Vol. XII. No 1. México, D.F. 1952.

Lunardi (Mons. Federico) : La Vida en las Tumbas. Río de Janeiro, 1935.

Lothrop (Samuel) : Pottery of Costa Rica and Nicaragua. Vol. I. New York, 1926.

Lothrop (Samuel) : An Archaeological Study of Central Panamá. Part. II. Cambridge, 1942.

Monconill M. (Mons. Gaspar) : Preparación del Tabaco entre los Uitoto. Revista Amazonia Colombiana Americanista. T. III. Nos. 9-10. Sibundoy, 1945.

Monconill M. (Mons. Gaspar) : Manera como preparan la "coca" los Uitoto en general. Revista Amazonia Colombiana Americanista. T. III. Nos. 9-10. Sibundoy, 1945.

Murdock (George Peter): Nuestros Contemporáneos Primitivos. México. Fondo de Cultura Económica. 1945.

Menendes Pidal (Gonzalo): Imagen del Mundo hacia 1570. Madrid, 1944.

Ortiz (Sergio (Elías): Informe sobre la Prehistoria del Departamento de Nariño. Boletín de Estudios Históricos. Vol. V. No 54. Pasto, 1934.

Ortiz (Sergio Elías) : Notas sobre los Indios Koaikeres. Revista Idearium. Organo de la Escuela Normal de Occidente. No 1 . Pasto, 1937.

Ortiz (Sergio Elías) : Familia Witoto. Pasto. Revista de Historia. No 1 , 1942.

Ortiz (Sergio Elías): The Modern Quillacinga, Pasto and Coiquer. Handbook of South American Indians, Vol. II. Washington, 1946.

PÉRez de Barradas (José): Arqueología y Antropología Precolombinas de Tierradentro. Bogotá, 1937.

Pérez de Barradas (José): Antigüedad del uso de la coca en Colombia. Revista de la Academia Colombiana de ciencias exactas, físicas y naturales. Vol. III. N⿳ 11. Bogotá, 1943.

Pardal (Ramón) : Medicina Aborigen Americana. Buenos Aires, 1937.

Pérez Arbeláez (Enrique): Plantas Medicinales de Colombia. Bogotá, 1937. 
Perú Indigena: El Problema de la Coca. Vol. III. Nos. 7 y 8. Lima, 1952. Pinell (Gaspar de) : Excursión apostólica por los ríos Putumayo, San Miguel de Sucumbios, Caquetá y Caguán. Bogotá. Imprenta Nacional, 1929.

Pupiales (Mateo) : La coca entre las tribus Uitoto de Tarapacá y Piuña Negro. Revista Amazonia Americanista. T. II. Nos. 9 y 10. Sibundoy, 1945.

Pérez de Barradas (José): Arqueología Agustiniana. Bogotá, 1943.

Pinell (Gaspar de) : Excursión apostólica por los ríos Putumayo, San Miguel de Sucumbios, Cuyabeno, Caquetá y Caguán. Bogotá, Imprenta Nacional. 1929.

Preuss (K. Th.): Arte Monumental Prehistórico. Traducción del alemán por el doctor Hermann Walde-Waldegg y doctor César Uribe Piedrahita. Bogotá, 1931.

Rivet (Paul) : La Langue Tunebo. Journal de la Societé des Americanistes. N.S. Tom. XXXIII. Paris, 1941.

Rivet (Paul) : La Langue Tunebo. Journal de la Societé des Americanisnistes. N.S. Tom. XXXIII. París, 1941.

Rivet (Paul): Origenes del Hombre Americano. México. Fondo de Cultura Económica. 1943.

Rivet y Openheim (Paul y Víctor) : La Lengua Tunebo. Revista del Instituto Etnológico Nacional. Vol. I. Entrega 1ª Bogotá, 1943.

Rapoort de la Commisión de étude sur la feuille de coca. Conseil économique et Social. Suplement Spécial. N ${ }^{\circ} 1$. New York, 1950.

Rocheraux (Pére H.): Les Indiens Tunebos et Pedrazas. Journal de la Societé del Americanistes. T. XI. París, 1919.

Ricketrs (Carlos A.) : La masticación de las hojas de Coca en el Perú. América Indígena. Vol. XIV. No 2. México. D.F. Abril, 1954.

Reichel-Dolmatoff (Gerardo y Alicia de): Grupos entre los indios Pijao del Tolima. Revista del Instituto Etnológico Nacional. Vol. 1. Entregas $1^{\text {a }}$ y $2^{\text {a }}$ Bogotá, 1944.

Reichel-Dolmatoff (Gerardo): Los Kógi. Tomo I. Revista del Instituto Etnológico Nacionai. Vol. IV. Entregas $1^{\text {a }}$ y $2^{\text {a }}$ Bogotá, 1949. 1950.

Reichel-Dolmatoff (Gerardo): Los Kógi. T. II. Editorial Iqueima. Bogotá, 1951.

Reichel-Dolmatoff (Gerardo): Contactos y Cambios Culturales en la Sierra Nevada de Sanla Marla. Revista Colombiana de Antropología. Segunda Epoca. Vol. I. No 1 Bogotá, 1953.

SEBEOK (Thomas A.) : Materials from aymará dictionary. Journal de la Socité de Americanistes. N.S. Tom. XL. Paris, 1951.

Wetstein (R.) : Tratado de botánica Sistemática. Madrid, 1944.

WavriN (Marquis de): Moeurs et costumes des indiens sauvages de la Amerique du Sud. París, 1937. 